\title{
34. CALCAREOUS NANNOFOSSILS OF DEEP SEA DRILLING PROJECT SITES 558 AND 563, NORTH ATLANTIC OCEAN: BIOSTRATIGRAPHY AND THE DISTRIBUTION OF OLIGOCENE BRAARUDOSPHAERIDS 1
}

\author{
Mary E. Parker, Murlene Clark, and Sherwood W. Wise, Jr., Department of Geology, Florida State University ${ }^{2}$
}

\begin{abstract}
Deep Sea Drilling Project Sites 558 and 563, located on the west flank of the Mid-Atlantic Ridge between 33 and $37^{\circ} \mathrm{N}$ latitude, yielded lower Oligocene through Pleistocene nannofossil-bearing sediments. A detailed study of the abundance, preservation, and biostratigraphic distribution of calcareous nannofossils at Sites 558 and 563 shows that preservation ranges from moderate to good and nannofossil assemblages are reasonably diverse. These long, continuously cored sections add substantially to the record of Tertiary nannofossiliferous sediments recovered in the North Atlantic. A hiatus of early Pliocene age is noted in Hole 558A, where the nannofossil Subzones CN10b, CN10c, and $\mathrm{CN11a}$ are missing. An increase in the relative abundance of triradiate forms of Discoaster brouweri proved useful in determining the LAD (last appearance datum) of $D$. brouweri in the presence of considerable reworking.

A significant occurrence of abundant braarudosphaerids, along with holococcoliths, was noted in the lower Oligocene section at Hole 563, but not at Hole $558,400 \mathrm{~km}$ to the north, an indication that a provincial nannofossil boundary separates the two sites. This first report of abundant Oligocene braarudosphaerids from the central North Atlantic Ocean suggests that they should be pervasive in Northern Hemisphere mid-latitude and subtropical lower Oligocene sediments deposited above $2700 \mathrm{~m}$. Together with Southern Hemisphere occurrences, this North Atlantic occurrence of braarudosphaerids may indicate a bipolar distribution in the maximum abundance of Oligocene Braarudosphaera.
\end{abstract}

\section{INTRODUCTION}

The purpose of this study is to describe the abundance, preservation, and biostratigraphic distribution of calcareous nannofossils at Sites 558 and 563. Any ecological differences expressed in the assemblages at each of these sites would also be of interest. The two sites (Fig. 1) are separated by $4^{\circ}$ of latitude (about $400 \mathrm{~km}$ ). Both were drilled on magnetic Anomaly 13, of early Oligocene age (site chapters, Sites 558 and 563, this volume). The oldest sediment, therefore, would have been deposited at or near the crest of the Mid-Atlantic Ridge at this time.

Although the Azores Triple Junction area has been studied extensively, few sedimentary sections have been continuously cored in that region. DSDP Leg 82 recovered the most complete section of Cenozoic pelagic sediments to date in the North Atlantic. Previous studies in the area have concentrated on crustal structure and geochemistry and include DSDP Legs 2, 37, and 49 (Peterson, Edgar, et al., 1970; Aumento, Melson, et al., 1977; Luyendyk, Cann, et al., 1979).

Both Sites 558 and 563 were cored down to basement. For this reason, the detailed discussions of the calcareous nannofossil biostratigraphy for each site begin at the base of each hole and then progress stratigraphically upward.

\section{METHODS}

One sample from each core section from Holes 558, 558A, and 563 was studied. Smear slides of all samples were made directly from raw

\footnotetext{
${ }^{1}$ Bougault, H., Cande, S. C., et al., Init. Repts. DSDP, 82: Washington (U.S. Govt. Printing Office).

2 Addresses: (Parker, Wise) Department of Geology, Florida State University, Tallahassee, Fl 32306; (Clark, present address) Department of Geology and Geography, University of South Alabama, Mobile, Alabama 36688.
}

sediment, according to the standard preparation technique, and were then examined on the light microscope. Calcareous nannofossils were abundant on all slides.

Smear slides were examined at a magnification of $1000 \times$ and the abundances of individual nannofossil species were tabulated on the range charts using the method proposed by Hay (1970). Estimates of the relative abundances of individual species in a given sample were made according to the following criteria:

$\mathrm{H}=$ highly abundant -101 to 1000 specimens per field of view at $1000 \times$;

$\mathrm{V}=$ very abundant -11 to 100 specimens per field of view at $1000 \times$;

$A=$ abundant -1 to 10 specimens per field of view at $1000 \times$;

$\mathrm{C}=$ common -1 specimen per 2 to 10 fields of view at $1000 \times$;

$\mathrm{F}=\mathrm{few}-1$ specimen per 11 to 100 fields of view at $1000 \times$; and

$R=$ rare -1 specimen per 101 to 1000 fields of view at $1000 \times$.

The abundances of reworked taxa and downhole contaminants are represented by lower-case letters.

A qualitative analysis of the state of preservation of the calcareous nannofossils found within each sample was made using the following criteria:

$\mathrm{G}=$ good-specimens exhibit little or no dissolution and/or overgrowth;

M-G = moderate to good-specimens exhibit slight to moderate dissolution and/or overgrowth, identification of some species is impaired;

$\mathbf{M}=$ moderate - specimens exhibit moderate dissolution and/or overgrowth, identification is impaired at the specific level; and

$\mathrm{P}=$ poor-specimens exhibit extreme dissolution and/or overgrowth.

These categories were determined based upon the "average" state of preservation of the calcareous nannofossils examined on the smear slides. There is generally considerable variation in the state of preservation of individual specimens observed in any given sample. Preservation ranged from moderate to good throughout the Leg 82 cored sedimentary sections.

Samples were prepared for scanning electron microscopy using procedures outlined by Wise and Kelts (1972). The samples were examined on a Cambridge Stereoscan S4-10 scanning electron microscope.

Species considered in this report are listed alphabetically by species epithets in the Appendix. Most of the bibliographic references for these taxa are presented in Loeblich and Tappan (1966; 1968; 1969; 1970a; 


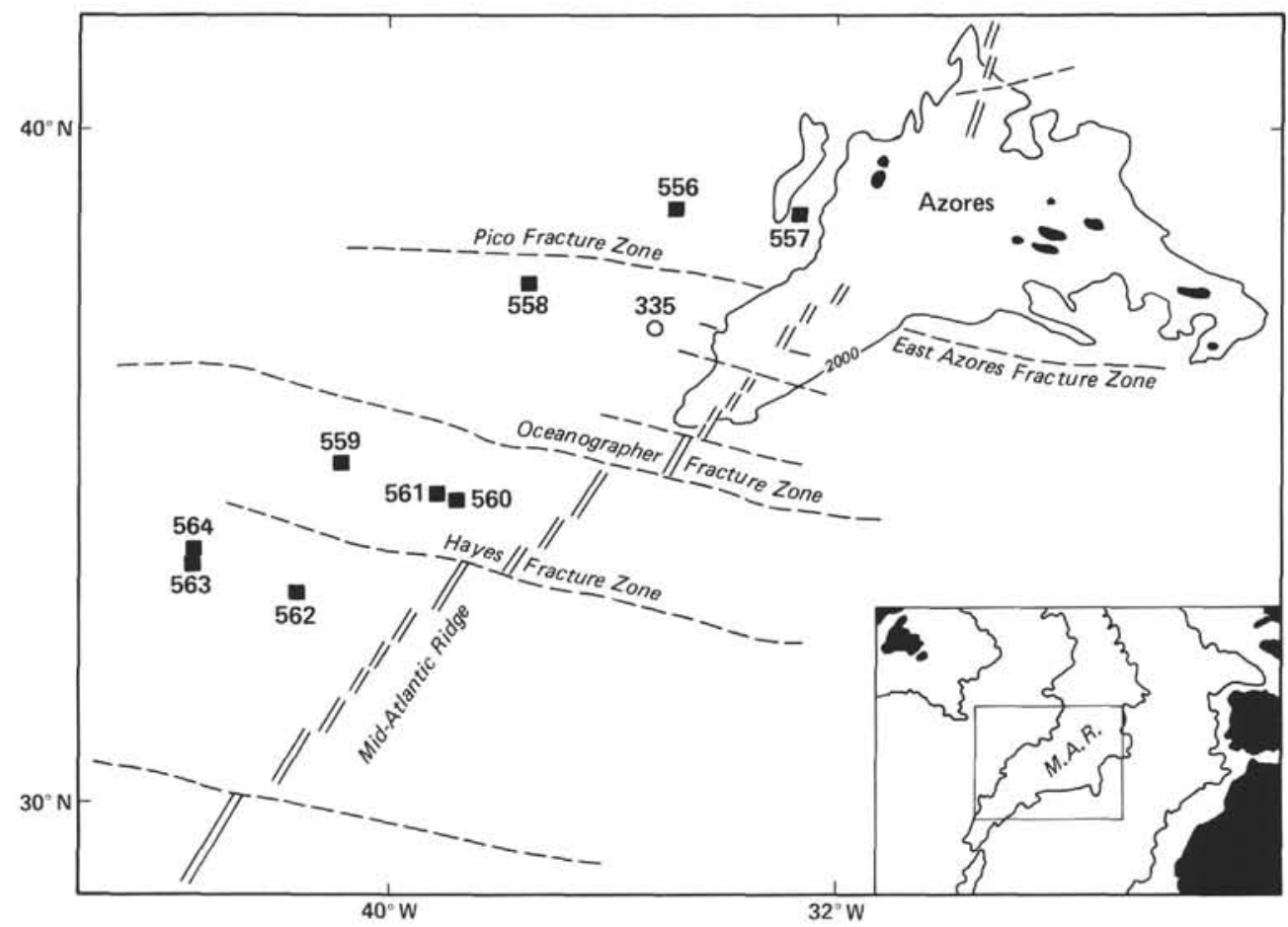

Figure 1. Location map for Deep Sea Drilling Project Leg 82 sites.

$1970 \mathrm{~b} ; 1971 ; 1973)$ and in van Heck $(1979 \mathrm{a} ; 1979 \mathrm{~b} ; 1980 \mathrm{a} ; 1980 \mathrm{~b}$; 1981a; 1981b; 1982a; 1982b; 1983a; 1983b). Any references not included in the above are listed in the references of this paper.

\section{BIOSTRATIGRAPHIC ZONATION}

Two published zonation schemes were used in this paper. For the Oligocene through Pliocene sections, Okada and Bukry's (1980) zonation was used; Gartner's (1977) zonation was used for the Pleistocene. This combination of zonations (Fig. 2) provides the highest degree of biostratigraphic resolution. Because both zonations use the last occurrence of Discoaster brouweri to date the Pliocene/Pleistocene boundary, the zonation scheme used in this paper is continuous. To avoid confusion, one should note that Calcidiscus (or Cyclococcolithina) macintyrei is used as a zone name by Gartner (1977), but as a subzone name for a different stratigraphic interval by Okada and Bukry (1980).

In some cases, preservation, scarcity of markers, and reworking problems limited the biostratigraphic resolution, and some zones and/or subzones could not be reliably discriminated. Dashed zonal and/or subzonal boundaries on the range charts indicate problems in discerning these boundaries. Reasons for the uncertainty about the position of such boundaries are outlined in detail in the discussions of the various sites. A synopsis of the calcareous nannofossil biostratigraphy for Sites 558 and 563 is presented in Figures 3 and 4.

A close comparison of the zonal assignments given in this chapter and those given in the site summaries for this volume will reveal some discrepancies. The site reports were compiled several months following the cruise and were based primarily on the examination of core- catcher samples. Because of the publication schedule established for this volume, there was no opportunity to modify that preliminary work after the more detailed examinations of the core sections were carried out.

\section{$\left(37^{\circ} 46.02^{\prime} \mathrm{N} ; 3^{\circ} 20.61^{\prime} \mathrm{W}\right.$; water depth $\left.=3766 \mathrm{~m}\right)$}

Site 558 was drilled about $48.3 \mathrm{~km}$ ( $30 \mathrm{mi}$.) south of the Pico Fracture Zone (Fig. 1) on the west flank of the Mid-Atlantic Ridge. Two holes were drilled in an attempt to recover a complete sedimentary section at this site. Unfortunately, the piston coring of the second hole had to be halted because of drilling problems before complete overlap of the sedimentary section was achieved. This left a $26 \mathrm{~m}$ stratigraphic gap between Holes 558 and 558A. However, this site does provide a nearly complete stratigraphic section from the lower Oligocene through the upper Pleistocene. It represents the first continuously cored section of lower Oligocene through Pleistocene calcareous pelagic sediments from the North Atlantic.

\section{Hole 558}

Hole 558 (Table 1) was washed down to a depth of $158 \mathrm{~m}$ and then continuously rotary cored for $250 \mathrm{~m}$ to basement. The lower Oligocene to upper Miocene sediments recovered contain abundant calcareous nannofossils. Preservation ranges from moderate to moderategood.

Samples 558-27-2, 42-44 cm through 558-25,CC are assigned to the lower Oligocene Helicosphaera reticulata Zone (CP16). Preservation throughout this zone is moderate, with substantial overgrowth and dissolution noted 


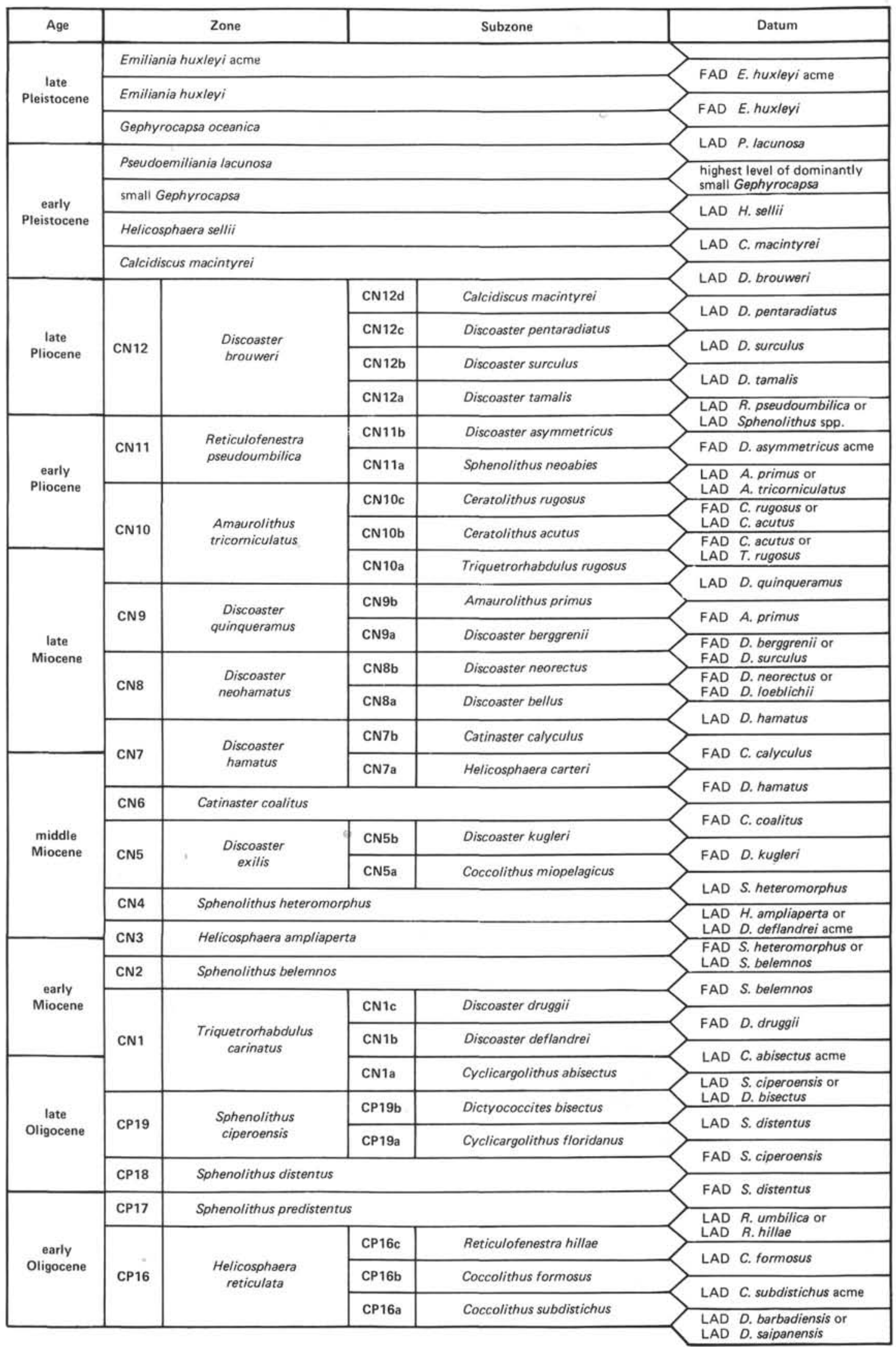

Figure 2. Zonation scheme used in this paper: adopted from Gartner (1977); Okada and Bukry (1980); with markers originally defined in Bukry $(1973 \mathrm{~b} ; 1975)$. FAD = first appearance datum; LAD = last appearance datum. 


\begin{tabular}{|c|c|c|c|c|}
\hline Age & Zone or subzone & Hole 558A & Hole 558 & Hole 563 \\
\hline \multirow{6}{*}{ 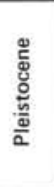 } & E. huxleyi & $1.1 / 2.4$ & \multirow{18}{*}{ Washed } & \multirow{18}{*}{ Washed } \\
\hline & G. oceanica & $2 \cdot 5 / 2, \mathrm{CC}$ & & \\
\hline & P. lacunosa/ & & & \\
\hline & small Gephyrocapsa & 3-1/6-1 & & \\
\hline & H. sellii & $6 \cdot 2 \sqrt{7} \cdot 1$ & & \\
\hline & C. macintyreil & $72 / 8-1$ & & \\
\hline \multirow{8}{*}{ 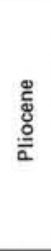 } & CN12d C. macintyrei & $1.270-1$ & & \\
\hline & CN12c D. pentaradiatus/ & $8.2 / 01$ & & \\
\hline & CN12b $\quad$ D. surculus & $8 \cdot 2 / 9-1$ & & \\
\hline & D. tamalis & $9 \cdot 2 / 9 \cdot 3$ & & \\
\hline & D. asymmetricus & $\overline{9} \cdot \overline{4} / \overline{9}, \bar{C} \bar{c}$ & & \\
\hline & S. neoabies & \multirow{3}{*}{ Hiatus } & & \\
\hline & C. rugosus & & & \\
\hline & C. acutus & & & \\
\hline \multirow{15}{*}{ 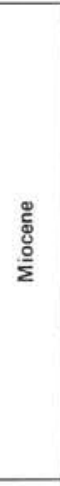 } & CN10a T. rugosus & $9, \mathrm{CC} / 12 \cdot 4$ & & \\
\hline & A. primus & $12.5 / 15, \mathrm{CC}$ & & \\
\hline & D. berggrenii & $16-1 / 16, \overline{C C}$ & & \\
\hline & D. neorectus & \multirow{2}{*}{ Uncored } & & \\
\hline & D. bellus & & $1.1 / 25$ & $1.1 / 2.5$ \\
\hline & D. hamatus & & $2.6 / 4.5$ & $2 \cdot 6 / 3, \mathrm{CC}$ \\
\hline & CN6/CN7 C. coalitus/D. hamatus & & $4 \cdot 6 / 4, \mathrm{CC}$ & \\
\hline & $\begin{array}{ll}\text { CN6 } & \text { C. coalitus } \\
\end{array}$ & & $5-1$ & 4.1 \\
\hline & D. kugleril & & \multirow{2}{*}{$5 \cdot 2 / 12 \cdot 1$} & \multirow{2}{*}{$4 \cdot 2 / 8, \mathrm{CC}$} \\
\hline & C. miopelagicus & & & \\
\hline & S. heteromorphus/ & & \multirow{2}{*}{$12-2 / 16-4$} & \multirow{2}{*}{$9 \cdot 1 / 12, \mathrm{CC}$} \\
\hline & H. amplificus & & & \\
\hline & S. belemnos & & $16-5 / 17 \cdot 1$ & $13-1 / 14, \mathrm{CC}$ \\
\hline & D. druggii & & $17 \cdot 2 / 18 \cdot 2$ & $15 \cdot 1 / 15 \cdot 5$ \\
\hline & D. deflandrei & & \multirow{2}{*}{$18-3 / 19 \cdot 3$} & $15 \cdot 6 / 15 \cdot 7$ \\
\hline \multirow{7}{*}{ 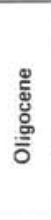 } & C. abisectus & & & $15, \mathrm{CC} / 16-5$ \\
\hline & D. bisectus & & $19.4 / 21, \mathrm{CC}$ & \multirow{2}{*}{$16-6 / 18, \mathrm{CC}$} \\
\hline & C. floridanus & & $22 \cdot 1 / 22, \mathrm{CC}$ & \\
\hline & S. distentus & & $23-1 / 24 \cdot 1$ & 19-1/19,CC \\
\hline & S. predistentus & & $24 \cdot 2 / 25 \cdot 6$ & $20-1 / 21.7$ \\
\hline & R. hillae & & $25, \mathrm{CC} / 26 \cdot 2$ & $21, \mathrm{CC} / 22-1$ \\
\hline & C. formosus & & $26 \cdot 3 / 27 \cdot 2$ & $22 \cdot 2 / 22, \mathrm{CC}$ \\
\hline
\end{tabular}

Figure 3. Zonal and geologic age assignments for cores from Sites 558 and 563, based on calcareous nannofossil assemblages. The highest and lowest sections are listed with a slash between them.

in the nannofossil assemblages. The discoasters present, $D$. deflandrei and $D$. tanii, are quite heavily overgrown, whereas the placoliths show the effects of dissolution.

No acme of Coccolithus subdistichus (included in Clausicoccus fenestratus) is present at the base of Hole 558 , indicating that the lowermost sediment core belongs to the $C$. formosus Subzone (CP16b). However, because acmes can be environmentally controlled, the assignment of 558-27-2, 42-44 cm through 558-26-3, $16-18 \mathrm{~cm}$ to this subzone is tentative, and this Oligocene assemblage may actually be slightly older. It should also be noted that because of overgrowth, perforation counts could not be made for the central area of specimens of Clausicoccus, so the various species of that genus could not be distinguished. In this study, therefore, all forms are categorized under $C$. fenestratus. Coccolithus formosus is generally abundant in the above interval. Coccolithus pelagicus, Cyclicargolithus floridanus, Discoaster deflandrei, Reticulofenestra bisecta, R. umbilica, Sphenolithus moriformis, and Zygrhablithus bijugatus are abundant to very abundant, whereas Bramletteius serraculoides and Isthmolithus recurvus are common.

The holococcolith Lanternithus minutus is common to abundant from 558-26-4, 16-18 cm through 558-25-3,

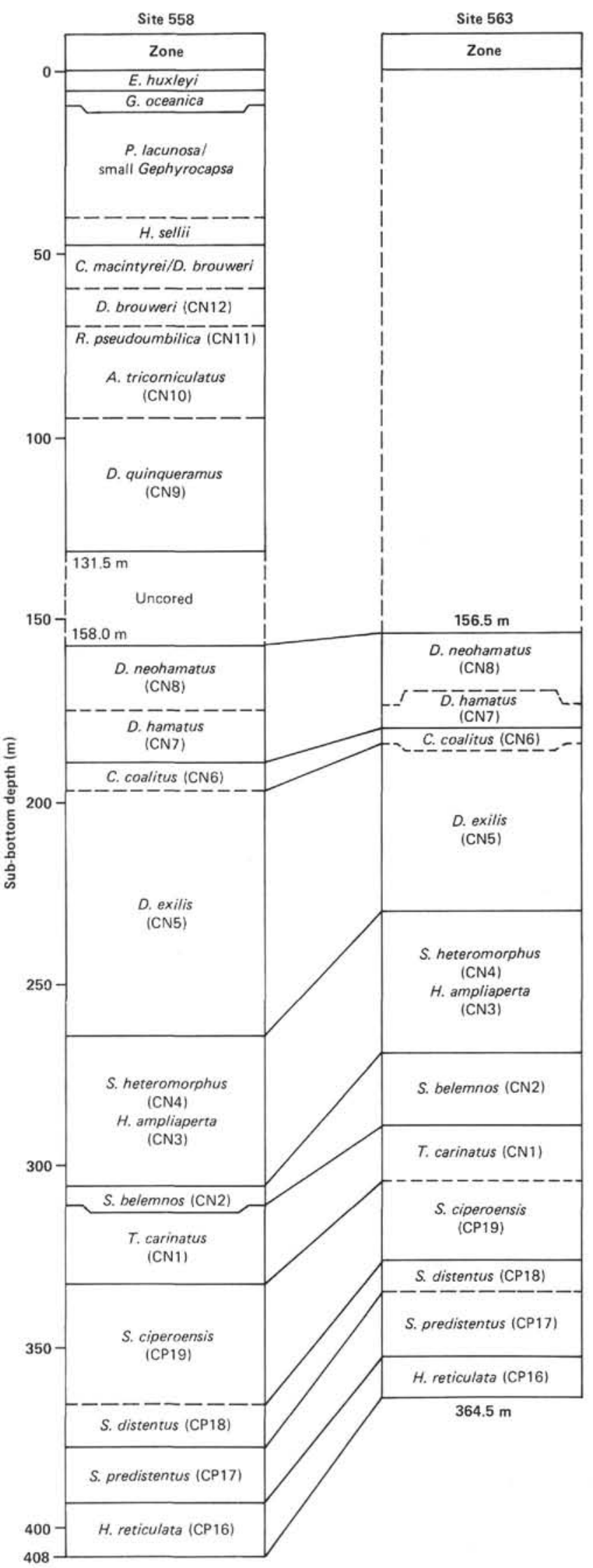

Figure 4. Zonal correlations for Sites 558 and 563. 
Table 1A. Distribution of calcareous nannofossils in Hole 558.

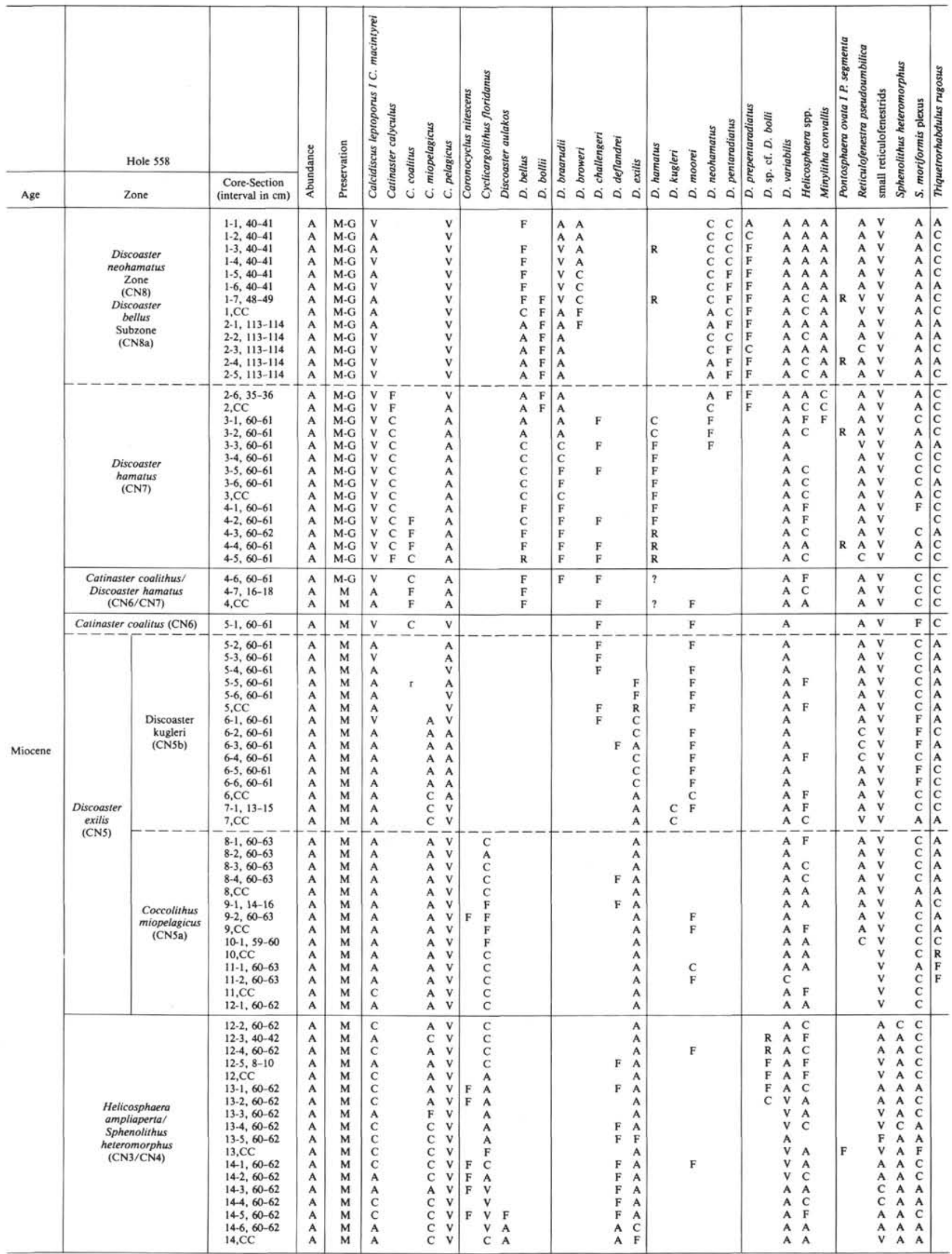


Table 1B. Distribution of calcareous nannofossils in Hole 558.

\begin{tabular}{|c|c|c|c|c|c|c|c|c|c|c|c|c|}
\hline \multicolumn{4}{|c|}{ Hole 558} & \multirow{2}{*}{ 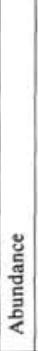 } & \multirow[t]{2}{*}{ : } & \multirow[t]{2}{*}{ 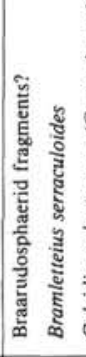 } & \multirow{2}{*}{\multicolumn{2}{|c|}{ 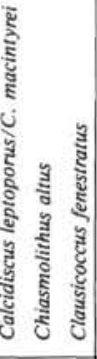 }} & \multirow{2}{*}{ 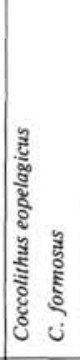 } & \multirow{2}{*}{ 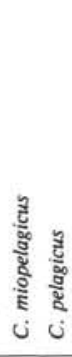 } & \multirow{2}{*}{\multicolumn{2}{|c|}{ 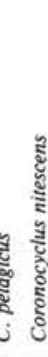 }} \\
\hline Age & Zone & Subzone & $\begin{array}{l}\text { Core-Section } \\
\text { (interval in cm) }\end{array}$ & & & & & & & & & \\
\hline \multirow{6}{*}{ Miocene } & \multicolumn{2}{|c|}{$\begin{array}{l}\text { Helicosphaera ampliapertal } \\
\text { Sphenolithus heteromorphus } \\
\text { (CN3 and CN4) }\end{array}$} & $\begin{array}{l}15-1,53-55 \\
15-2,6-8 \\
15-3,60-62 \\
15-4,60-62 \\
15-5,78-80 \\
15-6,78-80 \\
15, C C \\
16-1,60-62 \\
16-2,60-62 \\
11-36,60-62 \\
16-4,60-62 \\
\end{array}$ & \begin{tabular}{|l|}
$A$ \\
$A$ \\
$A$ \\
$A$ \\
$A$ \\
$A$ \\
$A$ \\
$A$ \\
$A$ \\
$A$ \\
$A$ \\
\end{tabular} & $\begin{array}{l}\mathrm{M} \\
\mathrm{M} \\
\mathrm{M} \\
\mathrm{M} \\
\mathrm{M} \\
\mathrm{M} \\
\mathrm{M} \\
\mathrm{M} \\
\mathrm{M} \\
\mathrm{M} \\
\mathrm{M} \\
\end{array}$ & & $\begin{array}{l}\text { A } \\
\text { A } \\
\text { A } \\
\text { A } \\
\text { C } \\
\text { C } \\
\text { C } \\
\text { F } \\
\text { F } \\
\text { F }\end{array}$ & & & $\begin{aligned} \mathrm{v} \\
\mathrm{V} \\
\mathrm{F} \\
\mathrm{V} \\
\mathrm{A} \\
\mathrm{v} \\
\mathrm{V} \\
\mathrm{v} \\
\mathrm{v} \\
\mathrm{v} \\
\mathrm{v}\end{aligned}$ & $\begin{array}{l}\text { V } \\
\text { V } \\
\text { V } \\
\text { V } \\
\text { A } \\
\text { V } \\
\text { V } \\
\text { V } \\
\text { V } \\
\text { V } \\
\text { V } \\
\text { S } \\
\end{array}$ & $\begin{array}{l}\text { F } \\
\text { F } \\
\text { C } \\
\text { C } \\
\text { A } \\
\text { A }\end{array}$ \\
\hline & \multicolumn{2}{|c|}{$\begin{array}{l}\text { Sphenolithus belemnos } \\
\text { (CN2) }\end{array}$} & $\begin{array}{l}16-5,60-62 \\
16-6,60-62 \\
16, C C \\
17-1,56-58\end{array}$ & \begin{tabular}{|l|}
$\mathrm{A}$ \\
$\mathrm{A}$ \\
$\mathrm{A}$ \\
$\mathrm{A}$ \\
\end{tabular} & \begin{tabular}{l|}
$\mathrm{M}$ \\
$\mathrm{M}$ \\
$\mathrm{M}$ \\
$\mathrm{M}$
\end{tabular} & & $\begin{array}{l}\mathrm{C} \\
\mathrm{F} \\
\mathrm{F} \\
\mathrm{F}\end{array}$ & & & & $\begin{array}{l}\mathrm{v} \\
\mathrm{v} \\
\mathrm{v} \\
\mathrm{v} \\
\end{array}$ & $\begin{array}{l}\text { A } \\
\text { C } \\
\text { A } \\
\text { A }\end{array}$ \\
\hline & \multirow{2}{*}{$\begin{array}{l}\text { Triquetro- } \\
\text { rhabdulus } \\
\text { carinatus } \\
\text { (CN1) }\end{array}$} & $\begin{array}{l}\text { Discoaster } \\
\text { druggii } \\
\text { (CNIc) }\end{array}$ & $\begin{array}{l}17-2,60-62 \\
17-3,60-62 \\
17-4,60-62 \\
17, C C \\
18-1,60-62 \\
18-2,60-62\end{array}$ & $\begin{array}{l}\mathrm{A} \\
\mathrm{A} \\
\mathrm{A} \\
\mathrm{A} \\
\mathrm{A} \\
\mathrm{A} \\
-\end{array}$ & $\begin{array}{l}\mathrm{M} \\
\mathrm{M} \\
\mathrm{M} \\
\mathrm{M} \\
\mathrm{M} \\
\mathrm{M} \\
\end{array}$ & & & & & $\begin{array}{ll} & \text { V } \\
\text { F } & \text { V } \\
\text { C } & \text { A } \\
\text { A } & \text { V } \\
\text { A } & \text { V } \\
\text { A } & \text { V }\end{array}$ & $\begin{array}{l}\mathrm{V} \\
\mathrm{V} \\
\mathrm{A} \\
\mathrm{V} \\
\mathrm{V} \\
\mathrm{v} \\
-\end{array}$ & $\begin{array}{l}\text { A } \\
\text { C } \\
\text { C } \\
\text { C } \\
\text { C } \\
\text { F }\end{array}$ \\
\hline & & $\begin{array}{c}\text { Cyclicargolithus } \\
\text { abisectus/ } \\
\text { Discoaster } \\
\text { deflandrei } \\
\text { (CNla/CNIb) }\end{array}$ & $\begin{array}{l}18-3,60-62 \\
18-4,60-62 \\
18, \mathrm{CC} \\
19-1,60-62 \\
19-2,60-62 \\
19-3,60-62\end{array}$ & \begin{tabular}{|l|}
$\mathrm{A}$ \\
$\mathrm{A}$ \\
$\mathrm{A}$ \\
$\mathrm{A}$ \\
$\mathrm{A}$ \\
$\mathrm{A}$ \\
\end{tabular} & $\begin{array}{l}\mathrm{M} \\
\mathrm{M} \\
\mathrm{M} \\
\mathrm{M} \\
\mathrm{M} \\
\mathrm{M}\end{array}$ & & & $\begin{array}{l}\mathrm{F} \\
\mathrm{A} \\
\mathrm{C}\end{array}$ & & $\begin{array}{ll}\mathrm{A} & \mathrm{V} \\
\mathrm{A} & \mathrm{A} \\
\mathrm{C} & \mathrm{V} \\
\mathrm{C} & \mathrm{V} \\
\mathrm{F} & \mathrm{V} \\
\mathrm{A} & \mathrm{V}\end{array}$ & $\begin{array}{l}\bar{v} \\
\text { A } \\
\text { v } \\
\text { v } \\
\text { v } \\
\mathrm{v}\end{array}$ & $\begin{array}{l}\text { C } \\
\text { C } \\
\text { C } \\
\text { C } \\
\text { A } \\
\text { C }\end{array}$ \\
\hline & $\begin{array}{l}\text { Sphenolithus } \\
\text { ciperoensis } \\
\text { (CP19) }\end{array}$ & $\begin{array}{l}\text { Dictyococcites } \\
\quad \text { bisectus } \\
\text { (CP19b) }\end{array}$ & $\begin{array}{l}19-4,60-62 \\
19-5,60-62 \\
19, C C \\
20-1,60-62 \\
20-2,60-62 \\
20-3,60-62 \\
20-4,60-62 \\
20-5,20-22 \\
20, C C \\
21-1,60-62 \\
21-2,60-62 \\
21-3,20-22 \\
21, C C\end{array}$ & \begin{tabular}{|l|}
$A$ \\
$A$ \\
$A$ \\
$A$ \\
$A$ \\
$A$ \\
$A$ \\
$A$ \\
$A$ \\
$A$ \\
$A$ \\
$A$ \\
$A$ \\
\end{tabular} & $\begin{array}{l}\mathrm{M} \\
\mathrm{M} \\
\mathrm{M} \\
\mathrm{M} \\
\mathrm{M} \\
\mathrm{M} \\
\mathrm{M} \\
\mathrm{M} \\
\mathrm{M} \\
\mathrm{M} \\
\mathrm{M} \\
\mathrm{M} \\
\mathrm{M} \\
\end{array}$ & & & $\begin{array}{l}\mathrm{F} \\
\mathrm{F} \\
\mathrm{C} \\
\mathrm{C} \\
\mathrm{C} \\
\mathrm{F} \\
\mathrm{F} \\
\mathrm{F} \\
\mathrm{F} \\
\mathrm{F} \\
\mathrm{C} \\
\mathrm{F} \\
\end{array}$ & $\begin{array}{l} \\
\\
\text { C } \\
\text { C } \\
\text { A } \\
\text { C } \\
\text { C } \\
\text { C } \\
\text { A } \\
\end{array}$ & 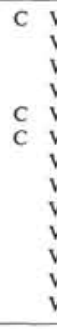 & 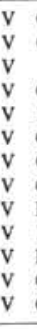 & $\begin{array}{l}\text { C } \\
\text { C } \\
\text { C } \\
\text { F } \\
\text { C } \\
\text { C } \\
\text { C } \\
\text { R } \\
\text { F } \\
\text { R } \\
\text { C } \\
\text { C }\end{array}$ \\
\hline & & $\begin{array}{l}\text { Cyclicargolithus } \\
\text { floridanus } \\
\text { (CP19a) }\end{array}$ & $\begin{array}{l}22-1,60-62 \\
22-2,600-62 \\
22-3,60-62 \\
22-4,60-62 \\
22, \mathrm{CC}\end{array}$ & $\begin{array}{l}\mathrm{A} \\
\mathrm{A} \\
\mathrm{A} \\
\mathrm{A} \\
\mathrm{A}\end{array}$ & $\begin{array}{l}M \\
M \\
M \\
M \\
M\end{array}$ & & & $\begin{array}{l}F \\
F \\
F \\
F\end{array}$ & $\begin{array}{l}\text { A } \\
\text { C } \\
\text { C } \\
\text { A } \\
\text { A }\end{array}$ & & & $\begin{array}{l}\mathrm{C} \\
\mathrm{C} \\
\mathrm{F} \\
\mathrm{C} \\
\mathrm{C}\end{array}$ \\
\hline \multirow[t]{4}{*}{ Oligocene } & \multicolumn{2}{|c|}{$\begin{array}{l}\text { Sphenolithus } \\
\text { distentus } \\
\text { (CP18) }\end{array}$} & $\begin{array}{l}23-1,30-32 \\
23-2,30-32 \\
23-3,30-32 \\
23-4,30-32 \\
23-5,30-32 \\
23-6,30-32 \\
23, \mathrm{CC} \\
24-1,40-42 \\
\end{array}$ & $\begin{array}{l}\mathrm{A} \\
\mathrm{A} \\
\mathrm{A} \\
\mathrm{A} \\
\mathrm{A} \\
\mathrm{A} \\
\mathrm{A} \\
\mathrm{A}\end{array}$ & $\begin{array}{l}\mathrm{M} \\
\mathrm{M} \\
\mathrm{M} \\
\mathrm{M} \\
\mathrm{M} \\
\mathrm{M} \\
\mathrm{M} \\
\mathrm{M}\end{array}$ & & $\begin{array}{l}\mathrm{F} \\
\mathrm{C} \\
\mathrm{R}\end{array}$ & \begin{tabular}{l|}
$\mathrm{F}$ \\
$\mathrm{C}$ \\
$\mathrm{F}$ \\
$\mathrm{F}$ \\
$\mathrm{F}$
\end{tabular} & $\begin{array}{l}\mathrm{A} \\
\mathrm{A} \\
\mathrm{A} \\
\mathrm{A} \\
\mathrm{C} \\
\mathrm{C} \\
\mathrm{A} \\
\mathrm{A}\end{array}$ & & $\begin{array}{l}\mathrm{v} \\
\mathrm{v} \\
\mathrm{v} \\
\mathrm{v} \\
\mathrm{y} \\
\mathrm{y} \\
\mathrm{v} \\
\mathrm{v} \\
\mathrm{y}\end{array}$ & $\begin{array}{l}\text { C } \\
\text { C } \\
\text { C } \\
\text { F } \\
\text { C } \\
\text { C } \\
\text { C } \\
\text { F }\end{array}$ \\
\hline & \multicolumn{2}{|c|}{$\begin{array}{l}\text { Sphenolithus } \\
\text { predistentus } \\
\text { (CP17) }\end{array}$} & $\begin{array}{l}24-2,40-42 \\
24-3,40-42 \\
24-4,40-42 \\
24, C C \\
25-1,97-99 \\
25-2,97-99 \\
25-3,97-99 \\
25-4,97-99 \\
25-5,97-99 \\
25-6,120-122 \\
\end{array}$ & $\begin{array}{l}\mathrm{A} \\
\mathrm{A} \\
\mathrm{A} \\
\mathrm{A} \\
\mathrm{A} \\
\mathrm{A} \\
\mathrm{A} \\
\mathrm{A} \\
\mathrm{A} \\
\mathrm{A} \\
\end{array}$ & $\begin{array}{l}\mathrm{M} \\
\mathrm{M} \\
\mathrm{M} \\
\mathrm{M} \\
\mathrm{M} \\
\mathrm{M} \\
\mathrm{M} \\
\mathrm{M} \\
\mathrm{M} \\
\mathrm{M}\end{array}$ & & $\begin{array}{l}\mathrm{A} \\
\mathrm{C} \\
\mathrm{F} \\
\mathrm{C} \\
\mathrm{C} \\
\mathrm{C} \\
\mathrm{C}\end{array}$ & \begin{tabular}{l|}
$\mathrm{R}$ \\
$\mathrm{F}$ \\
$\mathrm{F}$ \\
$\mathrm{F}$ \\
$\mathrm{F}$ \\
$\mathrm{C}$ \\
$\mathrm{F}$ \\
$\mathrm{F}$ \\
$\mathrm{F}$ \\
$\mathrm{F}$ \\
\end{tabular} & $\begin{array}{l}\text { A } \\
\text { A } \\
\text { A } \\
\text { C } \\
\text { C } \\
\text { A } \\
\text { C } \\
\text { A } \\
\text { A } \\
\text { C } \\
\end{array}$ & & & $\begin{array}{l}\text { C } \\
\text { F } \\
\text { C } \\
\text { F } \\
\text { C } \\
\text { C } \\
\text { C } \\
\text { C } \\
\text { F }\end{array}$ \\
\hline & \multirow[b]{2}{*}{$\begin{array}{l}\text { Helica- } \\
\text { sphaera } \\
\text { reticulata } \\
\text { (CP16) }\end{array}$} & $\begin{array}{l}\text { Reticulofenestra } \\
\text { hillae } \\
\text { (CPI6c) } \\
\end{array}$ & $\begin{array}{l}25, \mathrm{CC} \\
26-1,16-18 \\
26-2,16-18 \\
\end{array}$ & $\begin{array}{l}\mathrm{A} \\
\mathrm{A} \\
\mathrm{A} \\
\end{array}$ & \begin{tabular}{|l|}
$\mathrm{M}$ \\
$\mathrm{M}$ \\
$\mathrm{M}$
\end{tabular} & $\mathrm{R} \quad \mathrm{R}$ & $\begin{array}{l}\mathrm{F} \\
\mathrm{F} \\
\mathrm{C}\end{array}$ & $\begin{array}{l}\mathrm{R} \\
\mathrm{C} \\
\mathrm{A}\end{array}$ & $\begin{array}{l}\mathrm{A} \\
\mathrm{A} \\
\mathrm{C}\end{array}$ & & $\begin{array}{l}\mathrm{v} \\
\mathrm{v} \\
\mathrm{v} \\
\end{array}$ & F \\
\hline & & $\begin{array}{c}\text { Coccolithus } \\
\text { formosus } \\
\text { (CP16b) } \\
?\end{array}$ & $\begin{array}{l}26-3,16-18 \\
26-4,16-18 \\
26-5,16-18 \\
26, C C \\
27-1,35-37 \\
27-2,42-44\end{array}$ & \begin{tabular}{l|}
$\mathrm{A}$ \\
$\mathrm{A}$ \\
$\mathrm{A}$ \\
$\mathrm{A}$ \\
$\mathrm{A}$ \\
$\mathrm{A}$
\end{tabular} & $\begin{array}{l}\mathrm{M} \\
\mathrm{M} \\
\mathrm{M} \\
\mathrm{M} \\
\mathrm{M} \\
\mathrm{M}\end{array}$ & $\begin{array}{ll}F & C \\
F & C \\
F & C \\
F & C \\
F & C \\
F & C\end{array}$ & $\mathrm{~F}$ & $\begin{array}{l}\mathrm{A} \\
\mathrm{C} \\
\mathrm{F}\end{array}$ & $\begin{array}{ll}\mathrm{A} & \mathrm{C} \\
\mathrm{A} & \mathrm{A} \\
\mathrm{C} & \mathrm{A} \\
\mathrm{C} & \mathrm{A} \\
\mathrm{C} & \mathrm{A} \\
\mathrm{C} & \mathrm{A}\end{array}$ & & $\begin{array}{l}\text { V } \\
\text { A } \\
\text { A } \\
\text { A } \\
\text { A } \\
\text { V }\end{array}$ & \\
\hline
\end{tabular}


Table 1B. (Continued).

\begin{tabular}{|c|c|c|c|c|c|c|c|c|c|c|c|c|c|c|c|c|c|}
\hline 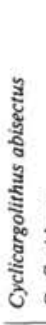 & 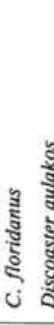 & 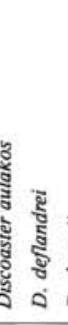 & & 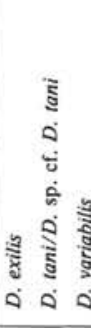 & 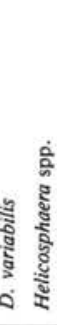 & 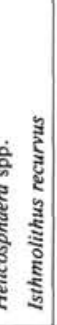 & 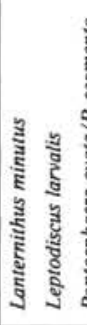 & 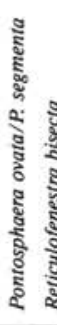 & 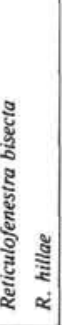 & 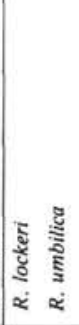 & 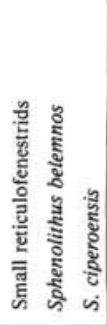 & 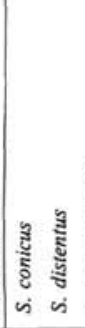 & 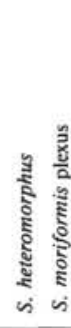 & 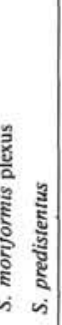 & 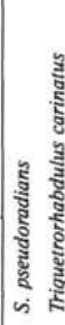 & 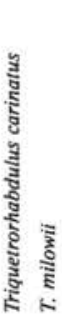 & 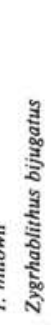 \\
\hline $\begin{array}{l}\text {. } \\
\\
\mathrm{F} \\
\mathrm{F}\end{array}$ & $\begin{array}{ll}\text { V } & \text { A } \\
\text { V } & \text { A } \\
\text { V } & \text { A } \\
\text { V } & \text { A } \\
\text { V } & \text { A } \\
\text { V } & \text { A } \\
\text { V } & \text { A } \\
\text { V } & \text { A } \\
\text { V } & \text { A } \\
\text { V } & \text { F } \\
\text { V } & \text { F }\end{array}$ & 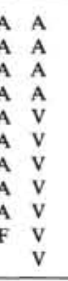 & & $\begin{array}{ll}\mathrm{F} & \mathrm{A} \\
\mathrm{F} & \mathrm{A} \\
\mathrm{F} & \mathrm{A} \\
& \mathrm{F}\end{array}$ & $\begin{array}{ll}A & A \\
A & A \\
A & F \\
F & F\end{array}$ & 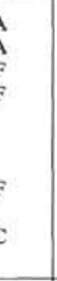 & & & & & $\begin{array}{l}\mathrm{A} \\
\mathrm{C}\end{array}$ & & $\begin{array}{ll}\mathrm{A} & \mathrm{A} \\
\mathrm{A} & \mathrm{A} \\
\mathrm{V} & \mathrm{V} \\
\mathrm{V} & \mathrm{V} \\
\mathrm{A} & \mathrm{A} \\
\mathrm{A} & \mathrm{A} \\
\mathrm{A} & \mathrm{V} \\
\mathrm{A} & \mathrm{V} \\
\mathrm{A} & \mathrm{A} \\
\mathrm{A} & \mathrm{A} \\
\mathrm{C} & \mathrm{V}\end{array}$ & $\begin{array}{l}A \\
A \\
\text { v } \\
\text { V } \\
A \\
A \\
\text { v } \\
\text { v } \\
\text { A } \\
\text { a } \\
\text { v }\end{array}$ & & $\begin{array}{l}\mathrm{F} \\
\mathrm{F} \\
\mathrm{C} \\
\mathrm{F} \\
\mathrm{F} \\
\mathrm{F} \\
\mathrm{F} \\
\mathrm{F} \\
\mathrm{C} \\
\mathrm{C} \\
\mathrm{A}\end{array}$ & \\
\hline $\begin{array}{l}\mathrm{F} \\
\mathrm{F} \\
\mathrm{C} \\
\mathrm{C}\end{array}$ & $\begin{array}{l}\mathrm{v} \\
\mathrm{v} \\
\mathrm{v} \\
\mathrm{v} \\
\end{array}$ & $\begin{array}{l}\mathrm{v} \\
\mathrm{v} \\
\mathrm{v} \\
\mathrm{v}\end{array}$ & F & & $F$ & $F$ & & & & & $\begin{array}{l}\text { A } \\
\text { A } \\
\text { A } \\
\text { A }\end{array}$ & & & $\begin{array}{l}A \\
A \\
A\end{array}$ & & $\begin{array}{ll}\mathrm{F} & \mathrm{A} \\
\mathrm{A} & \mathrm{C} \\
\mathrm{F} & \mathrm{C} \\
\mathrm{C} & \mathrm{C} \\
\end{array}$ & \\
\hline $\begin{array}{l}\text { A } \\
\text { A } \\
\text { C } \\
\text { A } \\
\text { A } \\
\text { A }\end{array}$ & $\begin{array}{l}\mathrm{v} \\
\mathrm{y} \\
\mathrm{v} \\
\mathrm{v} \\
\mathrm{v} \\
\mathrm{v}\end{array}$ & $\begin{array}{l}\mathrm{v} \\
\mathrm{v} \\
\mathrm{v} \\
\mathrm{v} \\
\mathrm{v} \\
\mathrm{v}\end{array}$ & \begin{tabular}{l|}
$\mathrm{c}$ \\
$\mathrm{c}$ \\
$\mathrm{C}$ \\
$\mathrm{F}$ \\
$\mathrm{C}$ \\
$\mathrm{c}$
\end{tabular} & $\begin{array}{l}\mathrm{F} \\
\mathrm{F} \\
\mathrm{F}\end{array}$ & & & & 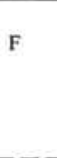 & & & & & & $\begin{array}{l}A \\
\text { v } \\
A \\
\text { v } \\
\text { v } \\
\text { v }\end{array}$ & & $\begin{array}{l}\mathrm{F} \\
\mathrm{F} \\
\mathrm{C} \\
\mathrm{A} \\
\mathrm{A} \\
\mathrm{A}\end{array}$ & $\begin{array}{l}\mathrm{F} \\
\mathrm{F}\end{array}$ \\
\hline $\begin{array}{l}\text { C } \\
\text { A } \\
\text { A } \\
\text { A } \\
\text { V } \\
\text { A }\end{array}$ & $\begin{array}{l}\mathrm{v} \\
\mathrm{v} \\
\mathrm{v} \\
\mathrm{v} \\
\mathrm{v} \\
\mathrm{v}\end{array}$ & $\begin{array}{l}\mathrm{v} \\
\mathrm{v} \\
\mathrm{v} \\
\mathrm{v} \\
\mathrm{v} \\
\mathrm{v}\end{array}$ & & $\begin{array}{l}\bar{R} \\
F \\
F \\
F \\
F \\
F\end{array}$ & $\begin{array}{l}\mathrm{F} \\
\mathrm{F} \\
\mathrm{F} \\
\mathrm{F} \\
\mathrm{F}\end{array}$ & 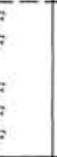 & & $\begin{array}{ll}\mathrm{F} & \mathrm{R} \\
& \mathrm{F} \\
& \mathrm{C} \\
\mathrm{F} & \mathrm{R} \\
& \mathrm{R}\end{array}$ & $\begin{array}{l}\mathrm{R} \\
\mathrm{F} \\
\mathrm{C} \\
\mathrm{R} \\
\mathrm{R}\end{array}$ & & & $\begin{array}{l}\text { C } \\
\text { A } \\
\text { F }\end{array}$ & & $\begin{array}{l}\bar{A} \\
\text { v } \\
\text { v } \\
\text { v } \\
\text { v } \\
\text { v }\end{array}$ & & $\begin{array}{l}\mathrm{A} \\
\mathrm{A} \\
\mathrm{A} \\
\mathrm{A} \\
\mathrm{A} \\
\mathrm{A}\end{array}$ & F \\
\hline $\begin{array}{l}\text { C } \\
\text { A } \\
\text { V } \\
\text { A } \\
\text { A } \\
\text { V } \\
\text { A } \\
\text { A } \\
\text { A } \\
\text { A } \\
\text { V } \\
\text { A } \\
\text { A }\end{array}$ & $\begin{array}{l}v \\
v \\
v \\
v \\
v \\
v \\
v \\
v \\
v \\
v \\
v \\
v \\
v \\
v\end{array}$ & $\begin{array}{l}\mathrm{v} \\
\mathrm{v} \\
\mathrm{v} \\
\mathrm{v} \\
\mathrm{v} \\
\mathrm{v} \\
\mathrm{v} \\
\mathrm{v} \\
\mathrm{v} \\
\mathrm{v} \\
\mathrm{v} \\
\mathrm{v} \\
\mathrm{v}\end{array}$ & & $\begin{array}{l}\text { F } \\
F \\
F \\
F \\
F \\
F \\
F \\
F \\
F \\
C \\
F \\
R\end{array}$ & $\begin{array}{l}\mathrm{F} \\
\mathrm{C}\end{array}$ & $c$ & & $\begin{array}{ll}\mathrm{F} & \mathrm{C} \\
\mathrm{F} & \mathrm{C} \\
\mathrm{F} & \mathrm{A} \\
\mathrm{F} & \mathrm{A} \\
\mathrm{F} & \mathrm{A} \\
& \mathrm{A} \\
\mathrm{F} & \mathrm{A} \\
\mathrm{F} & \mathrm{A} \\
\mathrm{F} & \mathrm{A} \\
\mathrm{F} & \mathrm{A} \\
\mathrm{F} & \mathrm{A} \\
\mathrm{F} & \mathrm{A} \\
\mathrm{F} & \mathrm{A}\end{array}$ & $\begin{array}{l}\text { C } \\
C \\
A \\
A \\
A \\
A \\
A \\
A \\
A \\
A \\
A \\
A \\
A \\
A\end{array}$ & & $\begin{array}{l}\text { C } \\
\text { A } \\
\text { C } \\
\text { A } \\
\text { A } \\
\text { A } \\
\text { A } \\
\text { A } \\
\text { A } \\
\text { A } \\
\text { A } \\
\text { A } \\
\text { C }\end{array}$ & F & $\begin{array}{l}v \\
v \\
v \\
v \\
v \\
v \\
v \\
v \\
v \\
v \\
v \\
v \\
v \\
v\end{array}$ & $\begin{array}{l}v \\
v \\
v \\
v \\
v \\
v \\
v \\
v \\
v \\
v \\
v \\
v \\
v \\
v \\
v\end{array}$ & & $\begin{array}{l}\mathrm{A} \\
\mathrm{A} \\
\mathrm{A} \\
\mathrm{A} \\
\mathrm{A} \\
\mathrm{A} \\
\mathrm{A} \\
\mathrm{A} \\
\mathrm{C} \\
\mathrm{A} \\
\mathrm{A} \\
\mathrm{A} \\
\mathrm{A}\end{array}$ & $\begin{array}{l}\text { A } \\
\text { A } \\
\text { A } \\
\text { A } \\
\text { A } \\
\text { A } \\
\text { C } \\
\text { C } \\
\text { A } \\
\text { A } \\
\text { A } \\
\text { A } \\
\text { A }\end{array}$ \\
\hline $\begin{array}{l}\mathrm{v} \\
\mathrm{v} \\
\mathrm{v} \\
\mathrm{v} \\
\mathrm{A} \\
\end{array}$ & $\begin{array}{l}\mathrm{v} \\
\mathrm{v} \\
\mathrm{v} \\
\mathrm{v} \\
\mathrm{v} \\
\mathrm{v}\end{array}$ & $\begin{array}{l}\text { A } \\
\text { V } \\
\text { V } \\
\text { A } \\
\text { A }\end{array}$ & & $\begin{array}{l}\mathbf{F} \\
\mathbf{C} \\
\mathbf{C} \\
\mathrm{C} \\
\mathrm{C}\end{array}$ & $F$ & F & & $\begin{array}{ll}\mathrm{C} & \mathrm{A} \\
\mathrm{F} & \mathrm{A} \\
\mathrm{F} & \mathrm{A} \\
\mathrm{F} & \mathrm{A} \\
& \mathrm{A}\end{array}$ & $\begin{array}{l}A \\
A \\
A \\
A \\
A\end{array}$ & $\mathbf{F}$ & $\begin{array}{l}\mathrm{R} \\
\mathrm{F} \\
\mathrm{R} \\
\mathrm{F} \\
\mathrm{F}\end{array}$ & $\begin{array}{l}\text { C } \\
\text { C } \\
\text { F } \\
\text { A } \\
\text { A }\end{array}$ & $\begin{array}{l}\mathrm{v} \\
\mathrm{v} \\
\mathrm{v} \\
\mathrm{v} \\
\mathrm{v}\end{array}$ & $\begin{array}{ll}V & A \\
V & A \\
V & C \\
V & C \\
V & C \\
V & A\end{array}$ & \begin{tabular}{|r|r|} 
& $\mathrm{C}$ \\
& $\mathrm{C}$ \\
& $\mathrm{F}$ \\
& $\mathrm{F}$ \\
$\mathrm{F}$ & $\mathrm{F}$ \\
\end{tabular} & $\begin{array}{l}\mathrm{C} \\
\mathrm{C} \\
\mathrm{F} \\
\mathrm{F} \\
\mathrm{F}\end{array}$ & $\begin{array}{l}\text { A } \\
\text { A } \\
\text { A } \\
\text { A } \\
\text { A }\end{array}$ \\
\hline $\begin{array}{l}\text { A } \\
\text { V } \\
\text { C } \\
\text { C } \\
\text { C } \\
\text { C } \\
\text { C } \\
\text { C }\end{array}$ & $\begin{array}{l}\mathrm{v} \\
\mathrm{v} \\
\mathrm{v} \\
\mathrm{v} \\
\mathrm{v} \\
\mathrm{v} \\
\mathrm{v} \\
\mathrm{v}\end{array}$ & $\begin{array}{l}\mathrm{A} \\
\mathrm{A} \\
\mathrm{A} \\
\mathrm{A} \\
\mathrm{A} \\
\mathrm{A} \\
\mathrm{A} \\
\mathrm{A}\end{array}$ & & $\begin{array}{l}\text { F } \\
\text { C } \\
\text { C } \\
\text { C } \\
\text { C } \\
\text { C } \\
\text { C } \\
\text { A }\end{array}$ & $\begin{array}{l}\mathrm{R} \\
\mathrm{C} \\
\mathrm{F} \\
\mathrm{F} \\
\mathrm{A} \\
\mathrm{C} \\
\mathrm{A}\end{array}$ & 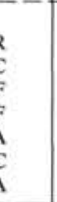 & 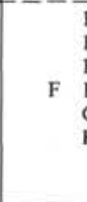 & $\begin{array}{ll}\mathrm{F} & \mathrm{A} \\
\mathrm{F} & \mathrm{A} \\
\mathrm{F} & \mathrm{A} \\
\mathrm{F} & \mathrm{A} \\
\mathrm{C} & \mathrm{A} \\
\mathrm{R} & \mathrm{A} \\
& \mathrm{A} \\
& \mathrm{A}\end{array}$ & $\begin{array}{l}A- \\
A \\
A \\
A \\
A \\
A \\
A \\
A \\
A\end{array}$ & $\begin{array}{l}\mathrm{F} \\
\mathrm{F} \\
\mathrm{F} \\
\mathrm{F} \\
\mathrm{F}\end{array}$ & & $\begin{array}{l}\text { A } \\
\text { A } \\
\text { A } \\
\text { A } \\
\text { A } \\
\text { A } \\
\text { C } \\
\text { C }\end{array}$ & $\begin{array}{l}\mathrm{v} \\
\mathrm{v} \\
\mathrm{v} \\
\mathrm{v} \\
\mathrm{v} \\
\mathrm{v} \\
\mathrm{v} \\
\mathrm{v}\end{array}$ & $\begin{array}{ll} & \bar{F} \\
V & F \\
V & F \\
V & C \\
V & A \\
V & A \\
V & A \\
V & A \\
V & A\end{array}$ & $\begin{array}{ll}\text { F } & \text { F } \\
F & F \\
\text { F } & \text { F } \\
F \\
F\end{array}$ & $\begin{array}{l}\bar{F} \\
\mathrm{~F} \\
\mathrm{~F}\end{array}$ & $\begin{array}{l}\text { A } \\
\text { A } \\
\text { V } \\
\text { A } \\
\text { A } \\
\text { V } \\
\text { A } \\
\text { A }\end{array}$ \\
\hline $\begin{array}{l}\text { C } \\
\text { C } \\
\text { C } \\
\text { C } \\
\text { C } \\
\text { C } \\
\text { A } \\
\text { A } \\
\text { C } \\
\text { C } \\
\end{array}$ & $\begin{array}{l}\mathrm{v} \\
\mathrm{v} \\
\mathrm{v} \\
\mathrm{y} \\
\mathrm{v} \\
\mathrm{v} \\
\mathrm{v} \\
\mathrm{v} \\
\mathrm{v} \\
\mathrm{v} \\
\mathrm{y}\end{array}$ & $\begin{array}{l}\mathrm{A} \\
\mathrm{A} \\
\mathrm{A} \\
\mathrm{A} \\
\mathrm{C} \\
\mathrm{A} \\
\mathrm{A} \\
\mathrm{A} \\
\mathrm{A} \\
\mathrm{A}\end{array}$ & & $\begin{array}{l}\text { A } \\
\text { A } \\
\text { A } \\
\text { A } \\
\text { C } \\
\text { A } \\
\text { A } \\
\text { C } \\
\text { A } \\
\text { A }\end{array}$ & $\begin{array}{l}\text { A } \\
\text { C } \\
\text { A } \\
\text { C } \\
\text { C } \\
\text { C } \\
\text { C } \\
\text { C } \\
\text { F } \\
\text { F }\end{array}$ & 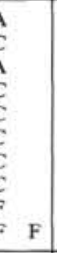 & 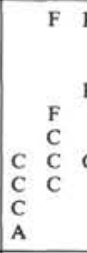 & $\begin{array}{ll}\mathrm{R} & \mathrm{A} \\
& \mathrm{A} \\
\mathrm{A} & \mathrm{A} \\
\mathrm{R} & \mathrm{A} \\
& \mathrm{A} \\
\mathrm{A} & \mathrm{A} \\
\mathrm{C} & \mathrm{A} \\
& \mathrm{A} \\
& \mathrm{A} \\
& \mathrm{A}\end{array}$ & $\begin{array}{l}\mathrm{A} \\
\mathrm{A} \\
\mathrm{A} \\
\mathrm{A} \\
\mathrm{A} \\
\mathrm{A} \\
\mathrm{A} \\
\mathrm{A} \\
\mathrm{A} \\
\mathrm{A}\end{array}$ & & & & $\begin{array}{l}\text { v } \\
\text { V } \\
\text { v } \\
\text { v } \\
\text { v } \\
\text { v } \\
\text { A } \\
\text { v } \\
\text { V } \\
\text { A }\end{array}$ & $\begin{array}{ll}\mathrm{V} & \mathbf{A} \\
\mathrm{V} & \mathrm{A} \\
\mathrm{V} & \mathrm{A} \\
\mathrm{V} & \mathrm{A} \\
\mathrm{V} & \mathrm{A} \\
\mathrm{V} & \mathrm{A} \\
\mathrm{A} & \mathrm{A} \\
\mathrm{V} & \mathrm{A} \\
\mathrm{V} & \mathrm{A} \\
\mathrm{A} & \mathbf{A}\end{array}$ & $\begin{array}{l}\mathrm{F} \\
\mathrm{F} \\
\mathrm{C} \\
\mathrm{F} \\
\mathrm{F} \\
\mathrm{F} \\
\mathrm{F} \\
\end{array}$ & & $\begin{array}{l}\text { A } \\
\text { A } \\
\text { A } \\
\text { A } \\
\text { V } \\
\text { A } \\
\text { A } \\
\text { A } \\
\text { V } \\
\text { V } \\
\end{array}$ \\
\hline $\begin{array}{l}\text { C } \\
\text { C } \\
\text { F }\end{array}$ & $\begin{array}{l}\mathrm{v} \\
\mathrm{v} \\
\mathrm{v}\end{array}$ & $\begin{array}{l}\text { A } \\
\text { A } \\
\text { A }\end{array}$ & & $\begin{array}{l}\mathrm{A} \\
\mathrm{A} \\
\mathrm{A}\end{array}$ & $\begin{array}{l}\text { F } \\
\text { A } \\
\text { C }\end{array}$ & $\begin{array}{l}c \\
c \\
c\end{array}$ & $\begin{array}{ll}A & \\
A & F \\
A & C\end{array}$ & $\begin{array}{r}\mathrm{A} \\
\mathrm{A} A \\
\mathrm{~A}\end{array}$ & $\begin{array}{ll}A & \\
A & F \\
A & F\end{array}$ & c & & & & $\begin{array}{ll}A & A \\
V & A \\
V & C\end{array}$ & $\begin{array}{l}\text { F } \\
\text { F }\end{array}$ & & $\begin{array}{l}\text { A } \\
\text { V } \\
\text { v }\end{array}$ \\
\hline & $\begin{array}{l}\mathrm{v} \\
\mathrm{v} \\
\mathrm{v} \\
\mathrm{v} \\
\mathrm{v} \\
\mathrm{v} \\
\mathrm{v}\end{array}$ & $\begin{array}{l}\text { A } \\
\text { A } \\
\text { A } \\
\text { A } \\
\text { A } \\
\text { V }\end{array}$ & & $\begin{array}{l}\text { C } \\
\text { C } \\
\text { A } \\
\text { A } \\
\text { A } \\
\text { A }\end{array}$ & & $\begin{array}{l}\mathrm{R} \\
\mathrm{C} \\
\mathrm{C} \\
\mathrm{C} \\
\mathrm{A} \\
\mathrm{A}\end{array}$ & $\begin{array}{l}\mathrm{C} \\
\mathrm{C}\end{array}$ & $\begin{array}{l}\mathrm{A} \\
\mathrm{A} \\
\mathrm{A} \\
\mathrm{A} \\
\mathrm{A} \\
\mathrm{A}\end{array}$ & $\begin{array}{cc}\mathrm{A} & \mathrm{C} \\
\mathrm{A} & \mathrm{C} \\
\mathrm{A} & \mathrm{A} \\
\mathrm{A} & \mathrm{A} \\
\mathrm{A} & \mathrm{A} \\
\mathrm{A} & \mathrm{A}\end{array}$ & $\begin{array}{l}\text { A } \\
\text { A } \\
\text { A } \\
\text { A } \\
\text { A } \\
\text { A }\end{array}$ & & & $\begin{array}{l}\text { A } \\
\text { A } \\
\text { A } \\
\text { A } \\
\text { A } \\
\text { V }\end{array}$ & $\begin{array}{ll}A & F \\
A & R \\
A & \\
A & \\
\text { V } & \end{array}$ & F & & $\begin{array}{l}\text { V } \\
\text { A } \\
\text { A } \\
\text { A } \\
\text { A } \\
\text { A }\end{array}$ \\
\hline
\end{tabular}


97-99 cm, but is heavily overgrown. A couple of very rare intact specimens of the genus Braarudosphaera were found in a sediment sample taken at the sediment/basalt contact. Calcite particles that may be from braarudosphaerid pentaliths were observed in the next few sections. However, because of the moderate preservation and the rarity of these particles, their identification must remain tentative.

Samples 558-26-2, 16-18 cm through 558-25,CC are placed in the Reticulofenestra hillae Subzone (CP16c). Reticulofenestra umbilica is common in 558-26-2, 16-18 $\mathrm{cm}$ and 558-26-1, 16-18 cm, but rare in Sample 55825, CC.

The holococcoliths L. minutus and Z. bijugatus occur abundantly in the $R$. hillae Subzone (CP16c). Clausicoccus fenestratus is generally common. Cyclicargolithus abisectus and Leptodiscus larvalis first appear in this subzone,

Because the lower size limit of $C$. abisectus was not set unequivocally by the author of the species or by any subsequent investigator, it is important to state the size criterion used here for distinguishing this taxon from $C$. floridanus. Based on measurements of the holotype, in our opinion, specimens must be $9 \mu \mathrm{m}$ or larger to be considered $C$. abisectus.

Samples 558-25-6, 120-122 cm through 558-24-2, 40-42 cm are assigned to the Sphenolithus predistentus Zone (CP17). Sphenolithus predistentus occurs abundantly throughout this zone. Both $I$. recurvus and $L$. minutus have their last appearances within the $S$. predistentus Zone (CP17). Few to common occurrences of $\mathrm{Co}$ ronocyclus nitescens are noted in this interval.

Samples 558-24-1, 40-42 cm through 558-23-1, 30-32 $\mathrm{cm}$ are placed in the middle Oligocene Sphenolithus distentus Zone (CP18). Preservation of the assemblages within this zone is moderate. Sphenolithus distentus is common to abundant throughout this interval. Specimens of Triquetrorhabdulus carinatus, although few in number, first appear in this zone. Zygrhablithus bijugatus remains abundant to very abundant.

Samples 558-22,CC through 558-19-4, 60-62 cm are assigned to the upper Oligocene Sphenolithus ciperoensis Zone (CP19). The lower zonal boundary is questionable due to the rare occurrences of $S$. ciperoensis, the zonal marker, throughout Core 558-22. Sphenolithus ciperoensis, being both small in size (4-6 $\mu \mathrm{m})$ and rare in these samples, could easily be missed during smear-slide examination. Alternatively, some might consider its presence in such small numbers to be the result of downhole contamination. Preservation is moderate throughout this zone.

The Cyclicargolithus floridanus Subzone (CP19a) is recognized in 558-22, CC through 558-22-1, 60-62 cm. Sphenolithus distentus and $S$. predistentus are common to abundant, but $S$. ciperoensis is generally rare. Specimens of $T$. carinatus are few to common in this interval.

Samples 558-21,CC through 558-19-4, 60-62 cm are placed in the Dictyococcites bisectus Subzone (CP19b). Sphenolithus ciperoensis is generally abundant throughout this subzone, as are $T$. carinatus and $Z$. bijugatus.
Although the last occurrence of Sphenolithus ciperoensis, the principal upper zonal marker for the $S$. ciperoensis Zone (CP19), is found in Section 558-19-4, Reticulofenestra bisecta, used as a secondary marker by Bukry $(1973 \mathrm{~b} ; 1975)$, persists in small numbers through 558-18-4, 60-62 cm. Roth et al. (1971) noted that $R$. bisecta has its last occurrence below the LAD (last appearance datum) of $S$. ciperoensis. Bukry (1973b) commented that the disappearance of $R$. bisecta near the LAD of $S$. ciperoensis at the top of the $S$. ciperoensis Zone (CP19) could be used as a guide for recognizing the top of this zone in high latitudes where $S$. ciperoensis may not be a useful marker. In this North Atlantic section, there could be several reasons for the occurrence of $R$. bisecta above the last occurrence of $S$. ciperoensis. One possibility is that the LAD of $R$. bisecta actually occurs somewhat higher than the LAD of $S$. ciperoensis. A second possibility is that the higher occurrences of $R$. bisecta represent reworking of this taxon. A third possibility is that $S$. ciperoensis may be absent or too rare to be a useful marker due to latitudinal considerations. This, however, seems unlikely because $S$. ciperoensis is common to abundant in many samples in this stratigraphic section. Therefore, we consider the occurrence of $S$. ciperoensis to be a reliable datum and attribute the high occurrences of $R$. bisecta to one of the first two possibilities discussed above.

Preservation is moderate in the Triquetrorhabdulus carinatus Zone (CN1), which spans the Oligocene/Miocene boundary. Samples 558-19-3, 60-62 cm through $558-17-2,60-62 \mathrm{~cm}$ are assigned to this zone. The Cyclicargolithus abisectus Subzone (CN1a) cannot be recognized in this section because $C$. abisectus occurs abundantly throughout the entire $T$. carinatus Zone. Obviously, the Discoaster deflandrei Subzone (CN1b) cannot be differentiated from the lower subzone because of the continued abundance of $C$. abisectus. Samples 558-19-3, 60-62 cm through 558-18-3, 60-62 cm are placed in the combined $C$. abisectus/D. deflandrei Subzones (CN1a and $\mathrm{CN} 1 \mathrm{~b}$ ) based on the absence of S. ciperoensis and of $D$. druggii.

Many discoasters may resemble $D$. druggii, especially when the preservation is poor. Large 6-rayed discoasters with bluntly rounded tips and broad central areas occur commonly and consistently in this section. These discoasters average about $20 \mu \mathrm{m}$ in diameter and are presumed to be $D$. druggii. However, because of overgrowth, absolute identification of these discoasters as $D$. druggii is impossible. Therefore, the D. druggii Subzone (CN1c) of the $T$. carinatus Zone is tentatively recognized in 558$18-2,60-62 \mathrm{~cm}$ through 558-17-2, 60-62 cm.

Occurrences of discoasters resembling $D$. tanii, designated $D$. sp. cf. D. tanii, are found as high as 558-17-3, 60-62 cm, within the $T$. carinatus Zone. In addition, Clausicoccus fenestratus ranges unusually high in this North Atlantic section. The last occurrence of Clausicoccus fenestratus is in the $T$. carinatus Zone (CN1) in Sample 558-18,CC. Specimens of $C$. fenestratus are few in number in this sample, but $C$. fenestratus occurs abundantly in 558-19-2, 60-62 cm. Roth (1970, p. 841) also 
recorded a long range for $C$. fenestratus in Trinidad, noting that it ranged through the $S$. ciperoensis $-T$. carinatus Zone (perhaps reworked). On the Falkland Plateau, Wise (1983) noted the abrupt disappearance of $C$. fenestratus s.1. in the lower Oligocene below the Reticulofenestra umbilica datum.

Samples 558-17-1, 56-58 cm through 558-16-5, 60-62 $\mathrm{cm}$ are assigned to the lower Miocene $S$. belemnos Zone (CN2). S. belemnos occurs abundantly throughout this interval. Triquetrorhabdulus milowii is common to abundant, but quite overgrown, as preservation is moderate in this zone.

Martini (1971) used the last occurrence of Triquetrorhabdulus carinatus as a zonal marker. According to Martini's zonation, the NN3 Zone, defined as the interval from the last occurrence of $T$. carinatus to the last occurrence of $S$. belemnos, would be absent in this section, because the last appearance of both $T$. carinatus and $S$. belemnos is in 558-16-5, 60-62 cm. Therefore, if Martini's (1971) zonation were followed here, a lower Miocene hiatus would be present. However, we do not consider $T$. carinatus a particularly reliable marker and do not specifically designate a hiatus at this point. Preservation is moderate, and $T$. carinatus is both broken and heavily overgrown and thus difficult to positively identify (see additional comments on this interval in the Hole 563 discussion).

Preservation of nannofossil assemblages is moderate in the lower to lower middle Miocene of Hole 558. Helicosphaera ampliaperta, if present, is very rare and difficult to identify. There are several placolith rims present in the various samples, but we could not positively identify any specimens of $H$. ampliaperta. Because we did not observe Helicosphaera ampliaperta, it is difficult to differentiate the $H$. ampliaperta Zone (CN3) from the overlying $S$. heteromorphus Zone (CN4). Alternative markers are discussed below but are considered generally unreliable in this North Atlantic section. Consequently, the $H$. ampliaperta Zone (CN3) is not separated from the $S$. heteromorphus Zone (CN4) in this study. Samples 558-16-4, 60-62 cm through 558-12-2, 60-62 cm are assigned to the combined $H$. ampliaperta/S. heteromorphus Zones (CN3 and CN4). Sphenolithus heteromorphus is generally abundant throughout this interval.

Various criteria have been used by different workers to separate the $H$. ampliaperta and $S$. heteromorphus Zones when $H$. ampliaperta is not present. Bukry (1973b), working in the low latitudes, used the end of the $D$. deflandrei acme. He noted that this datum occurs at the top of the $H$. ampliaperta Zone and is distinctive in low latitude areas. However, the use of an acme to define a zonal boundary is not generally desirable, because the end of an acme may vary from place to place for a variety of reasons. Site 558 is not considered a low latitude DSDP site, and it is highly questionable whether the end of the $D$. deflandrei acme in 558-14-5, 60-62 cm coincides with the top of the $H$. ampliaperta Zone.

In the Site 558 chapter (this volume), the first appearance of long-armed discoasters was used to separate the $H$. ampliaperta (CN3) and S. heteromorphus (CN4) Zones. Discoaster variabilis, the first long-armed disco- aster to appear in the column, first occurs in 558-15-4, $60-62 \mathrm{~cm}$. Discoaster variabilis is few in number in this sample and abundant in higher samples.

Jiang and Gartner (1984) noted that, in the absence of $H$. ampliaperta, the first common occurrence of Discoaster variabilis can be used to subdivide the $H$. ampliaperta and $S$. heteromorphus Zones. On their range charts, Jiang and Gartner used the first appearance of D. variabilis even if numbers were few instead of common. Discoaster deflandrei was often common both above and below this level. To indicate uncertainty, Jiang and Gartner dashed the zonal boundary.

It is apparent that the positioning of any boundary between the $H$. ampliaperta and $S$. heteromorphus Zones in this section would be highly subjective. There is a difference of approximately one entire core between the boundary determined by the use of the end of the $D$. deflandrei acme and that determined by the use of the first appearance of long-armed discoasters. A shift in dominance among the discoasters from $D$. deflandrei to longarmed discoasters such as $D$. variabilis and $D$. exilis has also been used to separate these zones. This change may occur at yet another level. In this section, D. exilis has its first occurrence and $D$. variabilis becomes abundant in 558-15-3, before the end of the $D$. deflandrei acme in 558-14-5. In summary, we choose not to separate the $H$. ampliaperta Zone (CN3) from the $S$, heteromorphus Zone (CN4) in this study, because we did not observe $H$. ampliaperta and because a reliable alternate marker is lacking in this North Atlantic section.

Heavily overgrown 6-rayed discoasters with large central areas $(6-8 \mu \mathrm{m})$ and large stellate stems, denoted as $D$. sp. cf. $D$. bollii on the range chart, occur commonly in 558-13-1, 60-62 cm and rarely in several overlying sections. These discoasters lack the tapered rays and bifurcated tips characteristic of $D$. bollii. Their occurrence in the $H$. ampliaperta/S. heteromorphus zones is stratigraphically lower than the occurrence of $D$. bollii.

Samples 558-12-1, 60-61 cm through 558-5-2, 60-62 $\mathrm{cm}$ are assigned to the middle Miocene Discoaster exilis Zone (CN5). Discoaster kugleri, the first appearance of which is used to subdivide this zone, occurs commonly in two samples in this interval, 558-7-1, 13-15 cm and $558-7, C$. Core recovery was very poor in Core 558-7; only $9 \%$ of the interval was recovered. Except for this species, there are no other significant first occurrences to serve as alternate markers. The last occurrence of $C y$ clicargolithus floridanus was used by Bukry (1975) as an auxiliary marker. However, $C$. floridanus has been found to occur commonly in the $D$. kugleri Subzone (CN5b) in some areas (Roth and Thierstein, 1972). In the present study, the last occurrence of $C$. floridanus is in 558-8-1, $60-63 \mathrm{~cm}$ and may be stratigraphically useful. Therefore, Samples 558-12-1, 60-62 cm through 558-8-1, 60-63 $\mathrm{cm}$ are assigned to the Coccolithus miopelagicus Subzone (CN5a). The upper subzonal boundary is dashed because preservation is moderate, and, although rare specimens of D. kugleri may be present below 558-7,CC, they would be difficult to identify. Samples 558-7,CC through 558-5-2, 60-62 cm are assigned to the Discoaster kugleri Subzone (CN5b). 
Sample 558-5-1, 60-61 cm is placed in the Catinaster coalitus Zone (CN6). Catinaster coalitus is common and preservation is moderate-good in this sample. The lower zonal boundary is dashed due to moderate preservation below Section 558-5-1 and difficulty in identifying Catinaster coalitus. In Sample 558-5-5, 60-61 cm, a couple of rare specimens of $C$. coalitus were found. In other samples, small (4-8 $\mu \mathrm{m})$, irregular, and generally circular particles of calcite are present that could be very heavily overgrown specimens of $C$. coalitus. Small discoasters of similar size are also present within this interval. Mobile mounts were made in an attempt to determine the presence of $C$. coalitus, but overgrowth was so extreme that positive identification was impossible. Therefore, the presence of rare C. coalitus in Section 558-5-5 may be the result of downhole contamination or may indicate extension of the $C$. coalitus Zone (CN6) downsection to at least this level, if not lower. In summary, it is likely that $C$. coalitus is present below $558-5-1,60-61 \mathrm{~cm}$, but preservation prohibits the placement of a definite lower zonal boundary.

Samples 558-4,CC through 558-4-6, 60-61 cm are placed in the Catinaster coalitus (CN6)/Discoaster hamatus (CN7) zones. Preservation ranges from moderate to moderate-good. Catinaster coalitus is few to common. Discoaster bellus first appears in 558-4,CC and is few in number throughout this interval. In addition, 5-rayed 14-16 $\mu \mathrm{m}$ discoasters which may be $D$. hamatus are few to rare and are denoted by a question mark on the range chart. These discoasters usually have broken arms and no larger specimens are present, so we can only tentatively identify these specimens as $D$. hamatus. Jiang and Gartner (1984) noted the first appearance of $D$. bellus and $D$. hamatus within the same sample in their South Atlantic study. If the first $D$. bellus can be used as an indicator of the base of the $D$. hamatus Zone (CN7), then CN7 would begin in 558-4,CC.

Samples 558-4-5, 60-61 cm through 558-2-6, 35-36 cm are assigned to the Discoaster hamatus Zone (CN7). Preservation is moderate-good throughout this interval. In Sections 558-4-5 through 558-4-3, specimens of $D$. hamatus are rare and small (14-16 $\mu \mathrm{m}$; the species was originally described as $16-25 \mu \mathrm{m}$ in diameter by Martini and Bramlette, 1963) and often have broken arms. Therefore, it is difficult to positively identify $D$. hamatus in this part of the zone. Catinaster calyculus, however, is easily identified and its presence indicates that these samples are in the $D$. hamatus Zone (CN7). Catinaster $c a-$ lyculus is generally common throughout the $D$. hamatus Zone of this hole. In 558-4-2, 60-61 cm, specimens of $D$. hamatus range up to $22-24 \mu \mathrm{m}$ in diameter. Discoaster hamatus is few to common from Section 558-4-2 through 558-2,CC. The upper zonal boundary is dashed because in $558-2-6,35-36 \mathrm{~cm}$, specimens of $D$. hamatus are 14-16 $\mu \mathrm{m}$, rare, broken, and difficult to positively identify. Catinaster calyculus, however, is still present. Because $558-2-6,35-36 \mathrm{~cm}$ is the last sample in which $C$. calyculus is found, the D. hamatus Zone should not extend above this level. The zonal boundary could be slightly lower, because $C$. calyculus may range into the Discoaster bellus Subzone (CN8a) of the Discoaster neohama- tus Zone (CN8). It is interesting to note that many specimens attributed here to $D$. bellus have rays that are somewhat curved at the ends, similar to those of $D$. brouweri.

Samples 558-2-5, 113-114 cm through 558-1-1, 40-41 $\mathrm{cm}$ are placed in the Discoaster bellus (CN8a) Subzone of the Discoaster neohamatus Zone (CN8), based in part on the presence of abundant Discoaster prepentaradiatus at the top of the interval. Preservation is moderategood.

\section{Hole 558A}

Hole 558A (Table 2) was hydraulically piston cored to a total depth of $132 \mathrm{~m}$ when mechanical problems in the inner core barrel forced termination prior to biostratigraphic overlap. Upper Miocene to upper Pleistocene sediments were recovered from this interval. The calcareous nannofossils are abundant and preservation is generally good. A minor hiatus is detected at the Miocene/Pliocene boundary.

Samples 558A-16,CC through 558A-12-5, 60-62 cm are assigned to the upper Miocene Discoaster quinqueramus Zone (CN9). Core 558A-16 is placed in the Discoaster berggrenii Subzone (CN9a). At the base of this subzone, $D$. loeblichii and $D$. berggrenii co-occur. Although this cooccurrence was not noted by Bukry (1973b), Proto-Decima et al. (1978) and Mazzei et al. (1979) noted the cooccurrence of these discoasters in their sections. Based on the presence of Amaurolithus primus and of D. quinqueramus, 558A-15,CC through 558A-12-5, 60-62 cm are assigned to the $A$. primus Subzone $(\mathrm{CN} 9 \mathrm{~b})$ of the $D$. quinqueramus Zone.

Samples 558A-12-4, 60-62 cm through 558A-9,CC $(14-16 \mathrm{~cm})$ are assigned to the Triquetrorhabdulus rugosus Subzone (CN10a) of the Amaurolithus tricorniculatus Zone (CN10). Few to common occurrences of $T$. rugosus are found in this interval. Reticulofenestra pseudoumbilica is very abundant. Numbers of sphenoliths vary from rare to abundant in this interval.

In 558A-9, CC a color change marks the position of a lower Pliocene hiatus. Sample 558A-9,CC $(9-11 \mathrm{~cm})$ contains abundant $R$. pseudoumbilica, common Discoaster tamalis and Discoaster asymmetricus, and few Sphenolithus spp. It is placed in the D. asymmetricus Subzone (CN11b) of the R. pseudoumbilica Zone (CN11). Subzone CN10b, CN10c, and CN11a of the lower Pliocene are absent.

Samples 558A-9,CC (9-11 cm) and 558A-9-4, 6-8 cm are assigned to the $D$. asymmetricus Subzone (CN11b). In 558A-9-4, 6-8 cm, Reticulofenestra pseudoumbilica is common and sphenoliths are few; this is the last consistent occurrence of both marker species. The upper boundary is uncertain due to reworking of $R$. pseudoumbilica and sphenoliths for a considerable distance upsection.

Samples 558A-9-3, 69-70 cm and 558A-9-2, 60-70 cm are placed in the Discoaster tamalis Subzone (CN12a) of the Discoaster brouweri Zone (CN12). Calcidiscus macintyrei, D. brouweri, D. pentaradiatus, D. surculus, Gephyrocapsa caribbeanica, Helicosphaera carteri, and Pseudoemiliania lacunosa are abundant in these samples. 
Discoaster tamalis is abundant in 558A-9-3, 69-70 cm and $\mathrm{few}$ in number in 558A-9-2, 69-70 $\mathrm{cm}$. The upper subzonal boundary is questionable due to reworking of D. tamalis. However, in higher samples D. tamalis is always rare and occurs sporadically.

Samples 558A-9-1, 127-128 cm through 558A-8-2, $70-71 \mathrm{~cm}$ are assigned to the combined Discoaster surculus $(\mathrm{CN} 12 \mathrm{~b})$ and Discoaster pentaradiatus $(\mathrm{CN} 12 \mathrm{c})$ Subzones of the $D$. brouweri Zone (CN12) based on the absence of $D$. tamalis and the presence of both $D$. surculus and $D$. pentaradiatus. Discoaster surculus and $D$. pentaradiatus are common to abundant in lower samples of this interval. In 558A-8-2, 70-71 cm, only a few specimens of $D$. pentaradiatus are present, and $D$. surculus is rare. The upper boundary is uncertain due to reworking of both $D$. surculus and $D$. pentaradiatus throughout the remainder of the section.

Samples 558A-8-1, 70-71 cm through 558A-7-4, 70-71 $\mathrm{cm}$ are placed in the Calcidiscus macintyrei Subzone (CN12d) of Bukry's Discoaster brouweri Zone (CN12). It is uncertain whether Sections 558A-7-3 and 558A-7-2 are in the C. macintyrei Subzone or Gartner's C. macintyrei Zone. In Section 558A-7-4, triradiate forms of $D$. brouweri are common; triradiate forms are rare below this section and few in 558A-7-3. An increased abundance of triradiate $D$. brouweri may be used to indicate proximity to the LAD (last appearance datum) of $D$. brouweri (see Discussion and Conclusions section). The last appearance of $C$. macintyrei is in 558A-7-2, 70-71 $\mathrm{cm}$, which also contains abundant 3-rayed and 6-rayed forms of $D$. brouweri. Above this sample, no 3-rayed forms of $D$. brouweri are found. The 6-rayed forms of $D$. brouweri drop in numbers to few or rare above 558A$7-2,70-71 \mathrm{~cm}$ and are considered to be reworked. A short hiatus may be present with the $C$. macintyrei Zone of Gartner (1977) absent.

Samples 558A-7-1, 70-71 cm through 558A-6-2, 60-62 $\mathrm{cm}$ are assigned to Gartner's (1977) Helicosphaera sellii Zone. Helicosphaera sellii is few to common in this interval. The upper zonal boundary is questionable due to reworking of $H$. sellii in overlying cores. Gephyrocapsa oceanica occurs abundantly in this zone. Reworked discoasters in this interval include $D$. brouweri (6-rayed), $D$. deflandrei, $D$. pentaradiatus, $D$. surculus, and $D$. variabilis. Discoaster brouweri is found in every sample, but it is generally rare. Other reworked species occur sporadically.

Samples 558A-6-1, 52-54 cm through 558A-3-1, 60-62 $\mathrm{cm}$ are placed in the combined small Gephyrocapsa and Pseudoemiliania lacunosa Zones based on the absence of $H$. sellii and the presence of $P$. lacunosa. The abundances of small gephyrocapsids are very consistent throughout this section, so Gartner's (1977) small Gephyrocapsa Zone cannot be distinguished. Pseudoemiliania lacunosa is abundant to very abundant. Reworked species in this interval include $D$. asymmetricus, $D$. brouweri (6-rayed), $D$. deflandrei, $D$. pentaradiatus, $D$. surculus, D. tamalis, D. variabilis, and $H$. sellii.

Samples 558A-2,CC through 558A-2-5, 60-62 cm are assigned to the Gephyrocapsa oceanica Zone. Calcidiscus leptoporus, Coccolithus pelagicus, Gephyrocapsa ca- ribbeanica, G. oceanica, $H$. carteri, and the small gephyrocapsids dominate the assemblages of this zone. There is considerable reworking in this interval, especially of discoasters.

Samples 558A-2-4, 60-62 cm through 558A-1-1, 44-45 $\mathrm{cm}$ are placed in the Emiliania huxleyi Zone based on the presence of $E$. huxleyi and confirmed by scanning electron microscopy. Reworked discoasters in this interval include $D$. deflandrei, $D$. pentaradiatus, $D$. surculus, and $D$. variabilis.

It is interesting to note that the interval of conspicuous reworking, which extends from the Discoaster surculus Zone to the present, coincides closely with the time of Northern Hemisphere glaciations as defined by Backman (1979) and Prell (1982). That being the case, this reworking probably reflects increased bottom current velocities associated with those glaciations.

\section{SITE 563}

$\left(33^{\circ} 38.53^{\prime} \mathrm{N} ; 4^{\circ} 46.04^{\prime} \mathrm{W}\right.$; water depth $\left.=3796 \mathrm{~m}\right)$

Site 563 is located on the west flank of the Mid-Atlantic Ridge about $96.5 \mathrm{~km}(60 \mathrm{mi}$.) south of the Hayes Fracture Zone (Fig. 1). Sediments recovered from the one hole drilled at this site consisted of calcareous pelagic ooze.

\section{Hole 563}

Hole 563 (Table 3) was washed down to $156.5 \mathrm{~m}$ before rotary coring was begun. The stratigraphic position of Core 563-1 was very close to that of Core 1 in Hole 558 (early late Miocene in age). The sedimentary section was then continuously cored from $156.5 \mathrm{~m}$ down to lower Oligocene basement at a depth of $364.5 \mathrm{~m}$. A section very similar to that in Hole 558 was recovered and yielded calcareous nannofossils ranging from early Oligocene to early late Miocene in age.

All major nannofossil zones Okada and Bukry (1980) for this part of the geologic column are recognized, and no hiatuses in the cored section are apparent. Calcareous nannofossils are abundant and preservation is moderate throughout this hole.

The interval from $563-22, \mathrm{CC}$ through $563-21, \mathrm{CC}$ is assigned to the lower Oligocene Helicosphaera reticulata Zone (CP16). The most unusual aspect of this assemblage is the presence of abundant braarudosphaerids along with the holococcoliths Lanternithus minutus, Peritrachelina joidesa, and Zygrhablithus bijugatus (Fig. 5). This is the first report of abundant braarudosphaerids from the central North Atlantic. They occur as whole pentaliths and as disaggregated segments and persist upsection through Core 563-20. Their association with holococcoliths may have some depth connotation (see discussion and conclusions section).

Gartner and Bukry (1969) provide an excellent summary of Tertiary holococcoliths, with descriptions and light and transmission electron microscope illustrations of well-preserved specimens of many holococcoliths. The holococcoliths present in Hole 563 are not pristine but have undergone considerable diagenetic alteration and are heavily overgrown, thereby making identification difficult. Specimens of $\boldsymbol{Z}$. bijugatus separate readily along 
M. E. PARKER, M. CLARK, S. W. WISE, JR.

Table 2A. Distribution of calcareous nannofossils in Hole 558A.

\begin{tabular}{|c|c|c|c|c|c|c|c|c|c|c|c|c|c|c|c|c|}
\hline & \multicolumn{2}{|c|}{ Hole $558 \mathrm{~A}$} & \multirow[b]{2}{*}{$\begin{array}{l}\text { Core-Section } \\
\text { (interval in cm) }\end{array}$} & \multirow{2}{*}{ 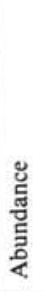 } & \multirow{2}{*}{ 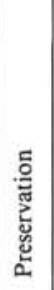 } & \multirow{2}{*}{ 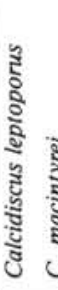 } & \multirow{2}{*}{\multicolumn{2}{|c|}{ 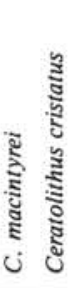 }} & \multirow{2}{*}{ 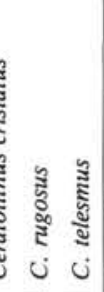 } & \multirow{2}{*}{ 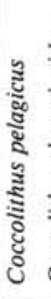 } & \multirow{2}{*}{ 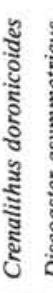 } & \multirow{2}{*}{\multicolumn{2}{|c|}{ 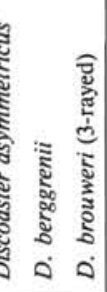 }} & \multirow{2}{*}{\multicolumn{2}{|c|}{ 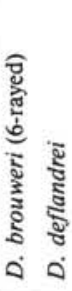 }} & \multirow{2}{*}{ 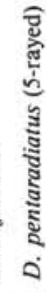 } \\
\hline Age & Zone & Subzone & & & & & & & & & & & & & & \\
\hline \multirow{5}{*}{$\begin{array}{l}\text { Pleisto- } \\
\text { cene }\end{array}$} & \multicolumn{2}{|c|}{ Emiliania huxleyi Zone } & $\begin{array}{l}1-1,44-45 \\
1, C C \\
2-1,60-62 \\
2-2,60-62 \\
2-3,60-62 \\
2-4,60-62\end{array}$ & $\begin{array}{l}\text { A } \\
\text { A } \\
\text { A } \\
\text { A } \\
\text { A } \\
\text { A }\end{array}$ & $\begin{array}{l}\text { G } \\
\text { G } \\
\text { G } \\
G \\
\text { G } \\
\text { G }\end{array}$ & $\begin{array}{l}\text { V } \\
\text { v } \\
\text { v } \\
\text { v } \\
\text { v } \\
\text { v }\end{array}$ & & $\begin{array}{l}F \\
F \\
F \\
F \\
F \\
F\end{array}$ & $\begin{array}{l}\mathrm{R} \\
\mathrm{R} \\
\mathrm{R} \\
\mathrm{R}\end{array}$ & $\begin{array}{l}\mathrm{A} \\
\mathrm{A} \\
\mathrm{A} \\
\mathrm{A} \\
\mathrm{A} \\
\mathrm{A}\end{array}$ & & & & & $\mathrm{r}$ & r \\
\hline & \multicolumn{2}{|c|}{ Gephyrocapsa oceanica Zone } & $\begin{array}{l}2-5,60-62 \\
2-6,60-62 \\
2, \text { CC }\end{array}$ & $\begin{array}{l}\text { A } \\
\text { A } \\
\text { A }\end{array}$ & $\begin{array}{l}\text { G } \\
\text { G } \\
\text { G }\end{array}$ & $\begin{array}{l}\mathrm{v} \\
\mathrm{v} \\
\mathrm{v}\end{array}$ & & $\begin{array}{l}\mathrm{R} \\
\mathrm{R} \\
\mathrm{R}\end{array}$ & & $\begin{array}{l}\text { A } \\
\text { A } \\
\text { C }\end{array}$ & & $\mathrm{r}$ & & $\begin{array}{l}f \\
f\end{array}$ & & $\begin{array}{l}\mathrm{r} \\
\mathrm{r}\end{array}$ \\
\hline & \multicolumn{2}{|c|}{$\begin{array}{c}\text { Pseudoemiliania } \\
\text { lacunosa/ } \\
\text { small Gephyrocapsa } \\
\text { zones }\end{array}$} & $\begin{array}{l}3-1,60-62 \\
3-2,60-62 \\
3-3,60-62 \\
3-4,64-66 \\
3-5,60-62 \\
3-6,60-62 \\
3, C C \\
4-1,60-62 \\
4-2,60-62 \\
4-3,60-62 \\
4-4,60-62 \\
4-5,60-62 \\
4-6,60-62 \\
4, C C \\
5-1,60-62 \\
5-2,60-62 \\
5-3,60-62 \\
5-4,60-62 \\
5-5,60-62 \\
5-6,60-62 \\
5, C C \\
6-1,52-54 \\
-\end{array}$ & $\begin{array}{l}\text { A } \\
\text { A } \\
\text { A } \\
\text { A } \\
\text { A } \\
\text { A } \\
\text { A } \\
\text { A } \\
\text { A } \\
\text { A } \\
\text { A } \\
\text { A } \\
\text { A } \\
\text { A } \\
\text { A } \\
\text { A } \\
\text { A } \\
\text { A } \\
\text { A } \\
\text { A } \\
\text { A } \\
\text { A } \\
\end{array}$ & $\begin{array}{l}G \\
G \\
G \\
G \\
G \\
G \\
G \\
G \\
G \\
G \\
G \\
G \\
G \\
G \\
G \\
G \\
G \\
G \\
G \\
G \\
G \\
G\end{array}$ & $\begin{array}{l}A \\
\text { V } \\
\text { V } \\
\text { V } \\
\text { V } \\
\text { V } \\
\text { V } \\
\text { V } \\
\text { V } \\
\text { V } \\
\text { V } \\
\text { V } \\
\text { V } \\
\text { V } \\
\text { V } \\
\text { V } \\
\text { V } \\
\text { V } \\
\text { V } \\
\text { V } \\
\text { V } \\
\text { V } \\
\text { - }\end{array}$ & r & R & & $\begin{array}{l}\mathrm{F} \\
\mathrm{R} \\
\mathrm{F} \\
\mathrm{R} \\
\\
\mathrm{C} \\
\\
\\
\mathrm{C} \\
\mathrm{A} \\
\mathrm{C} \\
\mathrm{C} \\
\mathrm{F} \\
\mathrm{A} \\
\mathrm{A} \\
\mathrm{C} \\
\mathrm{A} \\
\mathrm{C} \\
\mathrm{F} \\
\end{array}$ & $\begin{array}{l}\text { A } \\
\text { C } \\
\text { F } \\
\text { A } \\
\text { V } \\
\text { V } \\
\text { V } \\
\text { V } \\
\text { V } \\
\text { V } \\
\text { A } \\
\text { A } \\
\text { A } \\
\text { V } \\
\text { V } \\
\text { A } \\
\text { C } \\
\text { C } \\
\text { C } \\
\text { A } \\
\text { A } \\
\text { V } \\
\end{array}$ & $r$ & & f & $r$ & r \\
\hline & \multicolumn{2}{|c|}{ Helicosphaera sellii Zone } & $\begin{array}{l}6-2,60-62 \\
6-3,60-62 \\
6-4,60-62 \\
6-5,60-62 \\
6-6,60-62 \\
6, C C \\
7-1,70-71\end{array}$ & $\begin{array}{l}\text { A } \\
\text { A } \\
\text { A } \\
\text { A } \\
\text { A } \\
\text { A } \\
\text { A }\end{array}$ & $\begin{array}{l}\text { G } \\
\text { G } \\
\text { G } \\
\text { G } \\
\text { G } \\
\text { G } \\
\text { G }\end{array}$ & $\begin{array}{l}\text { v } \\
\text { v } \\
\text { v } \\
\text { v } \\
\text { v } \\
\text { v } \\
\text { v }\end{array}$ & & $\begin{array}{l}R \\
R\end{array}$ & & & & & & $\begin{array}{l}\mathrm{f} \\
\mathrm{r} \\
\mathrm{r} \\
\mathrm{r} \\
\mathrm{r} \\
\mathrm{r} \\
\mathrm{r}\end{array}$ & 列 & $\begin{array}{l}\mathrm{r} \\
\mathrm{r} \\
\mathrm{r} \\
\mathrm{r} \\
\mathrm{r}\end{array}$ \\
\hline & \multicolumn{2}{|c|}{$\begin{array}{l}\text { Calcidiscus macintyrei } \\
\text { Zone }\end{array}$} & $\begin{array}{l}7-2,70-71 \\
7-3,70-71\end{array}$ & $\begin{array}{l}\text { A } \\
\text { A }\end{array}$ & $\begin{array}{l}G \\
G\end{array}$ & $\begin{array}{l}\mathrm{v} \\
\mathrm{v}\end{array}$ & $\begin{array}{l}\text { A } \\
\text { A }\end{array}$ & R & & $\begin{array}{l}\text { A } \\
\text { A }\end{array}$ & $\begin{array}{l}\mathrm{A} \\
\mathrm{V}\end{array}$ & & $\begin{array}{l}\mathrm{A} \\
\mathrm{F}\end{array}$ & A & & $\begin{array}{l}\mathrm{r} \\
\mathrm{r}\end{array}$ \\
\hline \multirow{4}{*}{ Pliocene } & \multirow{3}{*}{$\begin{array}{c}\text { Discoaster } \\
\text { brouweri } \\
\text { (CN12) }\end{array}$} & $\begin{array}{l}\text { C. macintyrei } \\
\text { Subzone } \\
\text { (CN12d) }\end{array}$ & $\begin{array}{l}7-4,70-71 \\
7-5,70-71 \\
7, \mathrm{CC} \\
8-1,70-71\end{array}$ & $\begin{array}{l}\bar{A} \\
\mathrm{~A} \\
\mathrm{~A} \\
\mathrm{~A}\end{array}$ & $\begin{array}{l}\bar{G} \\
G \\
G \\
G\end{array}$ & $\begin{array}{l}\text { V } \\
\text { A } \\
\text { V } \\
\text { V }\end{array}$ & $\begin{array}{l}\mathrm{A} \\
\mathrm{A} \\
\mathrm{A} \\
\mathrm{A}\end{array}$ & $\begin{array}{l}R \\
R\end{array}$ & & $\begin{array}{l}\text { A } \\
\text { A } \\
\text { A } \\
\text { A }\end{array}$ & $\begin{array}{ll}\bar{v} & \\
\mathrm{v} & \\
\mathrm{v} & \mathrm{r} \\
\mathrm{v} & \end{array}$ & $\mathrm{r}$ & $\begin{array}{l}\bar{C} \\
\mathrm{R} \\
\mathrm{R} \\
\mathrm{R}\end{array}$ & $\begin{array}{l}\mathrm{A} \\
\mathrm{A} \\
\mathrm{A} \\
\mathrm{A}\end{array}$ & r & $\begin{array}{l}\cdot \\
r \\
r\end{array}$ \\
\hline & & $\begin{array}{c}\text { Discoaster } \\
\text { pentaradiatus/ } \\
\text { D. surculus } \\
\text { (CN12b/CN12c) }\end{array}$ & $\begin{array}{l}8-2,70-71 \\
8-3,70-71 \\
8-4,70-71 \\
8-5,70-71 \\
8, C C \\
9-1,127-128\end{array}$ & $\begin{array}{l}\mathrm{A} \\
\mathrm{A} \\
\mathrm{A} \\
\mathrm{A} \\
\mathrm{A} \\
\mathrm{A}\end{array}$ & $\begin{array}{l}\bar{G} \\
G \\
G \\
G \\
G \\
G\end{array}$ & $\begin{array}{l}\text { v } \\
\text { v } \\
\text { v } \\
\text { v } \\
\text { v } \\
\text { v }\end{array}$ & $\begin{array}{l}\text { A } \\
\text { A } \\
\text { A } \\
\text { A } \\
\text { A } \\
\text { A }\end{array}$ & & $\begin{array}{l}R \\
R \\
F \\
F\end{array}$ & $\begin{array}{l}\mathrm{A} \\
\mathrm{V} \\
\mathrm{A} \\
\mathrm{V} \\
\mathrm{V} \\
\mathrm{V}\end{array}$ & $\begin{array}{l}\text { v } \\
\text { V } \\
\text { v } \\
\text { v } \\
\text { v } \\
\text { v }\end{array}$ & & $\begin{array}{l}\mathrm{R} \\
\mathrm{R} \\
\mathrm{R} \\
\mathrm{R}\end{array}$ & $\begin{array}{l}\mathrm{C} \\
\mathrm{A} \\
\mathrm{A} \\
\mathrm{A} \\
\mathrm{A} \\
\mathrm{A}\end{array}$ & & $\begin{array}{l}\text { F } \\
\text { A } \\
\text { A } \\
\text { A } \\
\text { A } \\
\text { C }\end{array}$ \\
\hline & & $\begin{array}{c}\text { Discoaster } \\
\text { tamalis (CN12a) }\end{array}$ & $\begin{array}{l}9-2,69-70 \\
9-3,69-70\end{array}$ & $\begin{array}{l}\text { A } \\
\text { A }\end{array}$ & $\begin{array}{l}G \\
G\end{array}$ & $\begin{array}{l}A \\
\text { V }\end{array}$ & $\begin{array}{l}\text { A } \\
\text { A }\end{array}$ & & $\mathrm{F}$ & & $\begin{array}{ll}\mathrm{V} & \mathrm{C} \\
\mathrm{V} & \mathrm{C}\end{array}$ & $\begin{array}{l}\mathrm{C} \\
\mathrm{C}\end{array}$ & & $\begin{array}{l}\text { A } \\
\text { A }\end{array}$ & & $\begin{array}{l}\text { A } \\
A\end{array}$ \\
\hline & $\begin{array}{l}\text { Reticulofenestra } \\
\text { pseudoumbilica } \\
\text { (CN11) }\end{array}$ & $\begin{array}{c}\text { Discoaster } \\
\text { asymmetricus } \\
\text { (CN11b) }\end{array}$ & $\begin{array}{l}9-4,6-8 \\
9, C C(9-11)\end{array}$ & $\begin{array}{l}\text { A } \\
\text { A }\end{array}$ & $\begin{array}{l}G \\
G\end{array}$ & $\begin{array}{l}\mathrm{v} \\
\mathrm{v}\end{array}$ & $\begin{array}{l}\mathrm{A} \\
\mathrm{A}\end{array}$ & & R & & $\begin{array}{ll}\mathrm{v} & \mathrm{C} \\
\mathrm{v} & \mathrm{C}\end{array}$ & $\begin{array}{l}\mathrm{C} \\
\mathrm{C}\end{array}$ & $\mathbf{R}$ & A & & $\begin{array}{l}\text { A } \\
\text { A }\end{array}$ \\
\hline
\end{tabular}


Table 2A. (Continued).

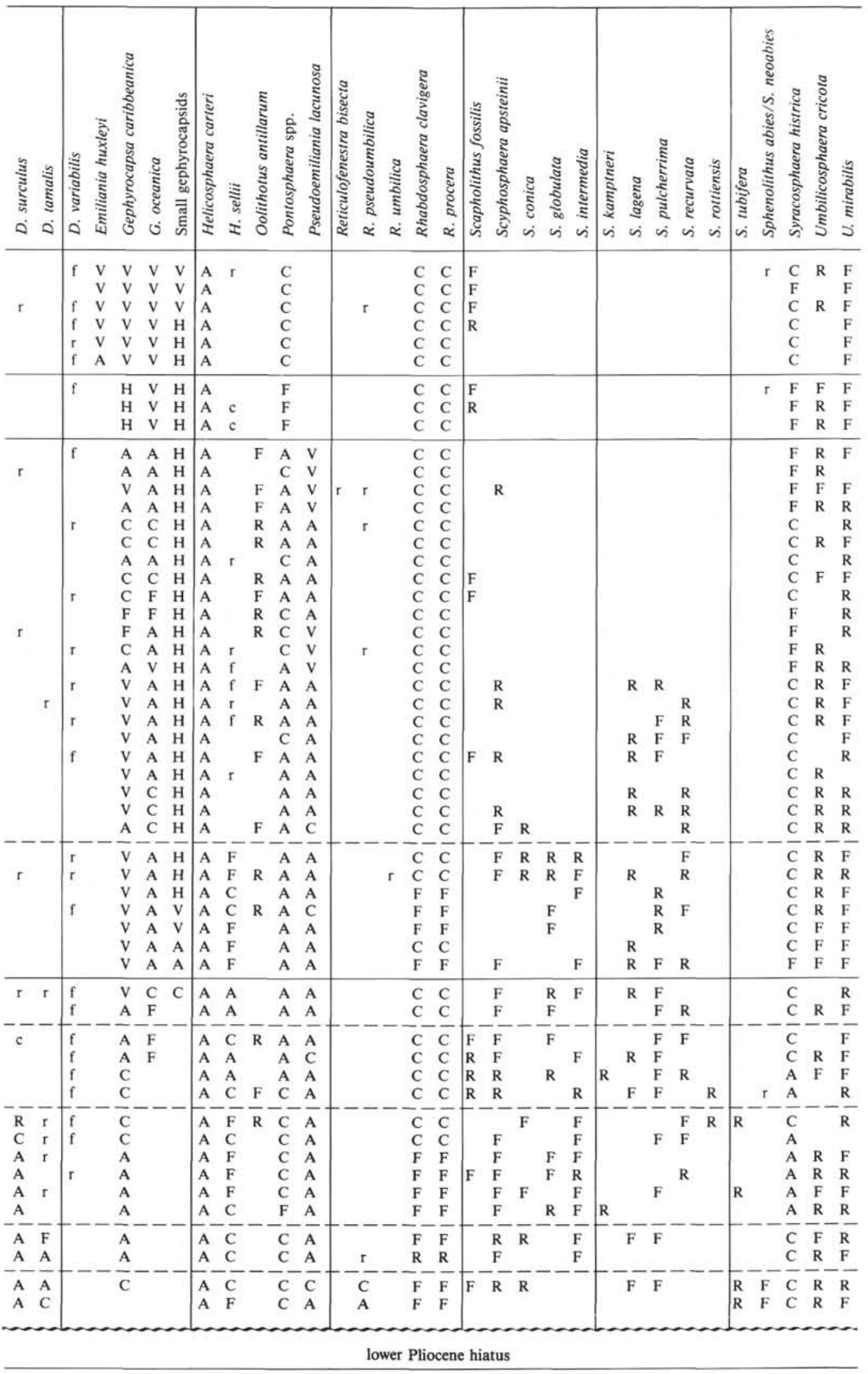


Table 2B. Distribution of calcareous nannofossils in Hole 558A.

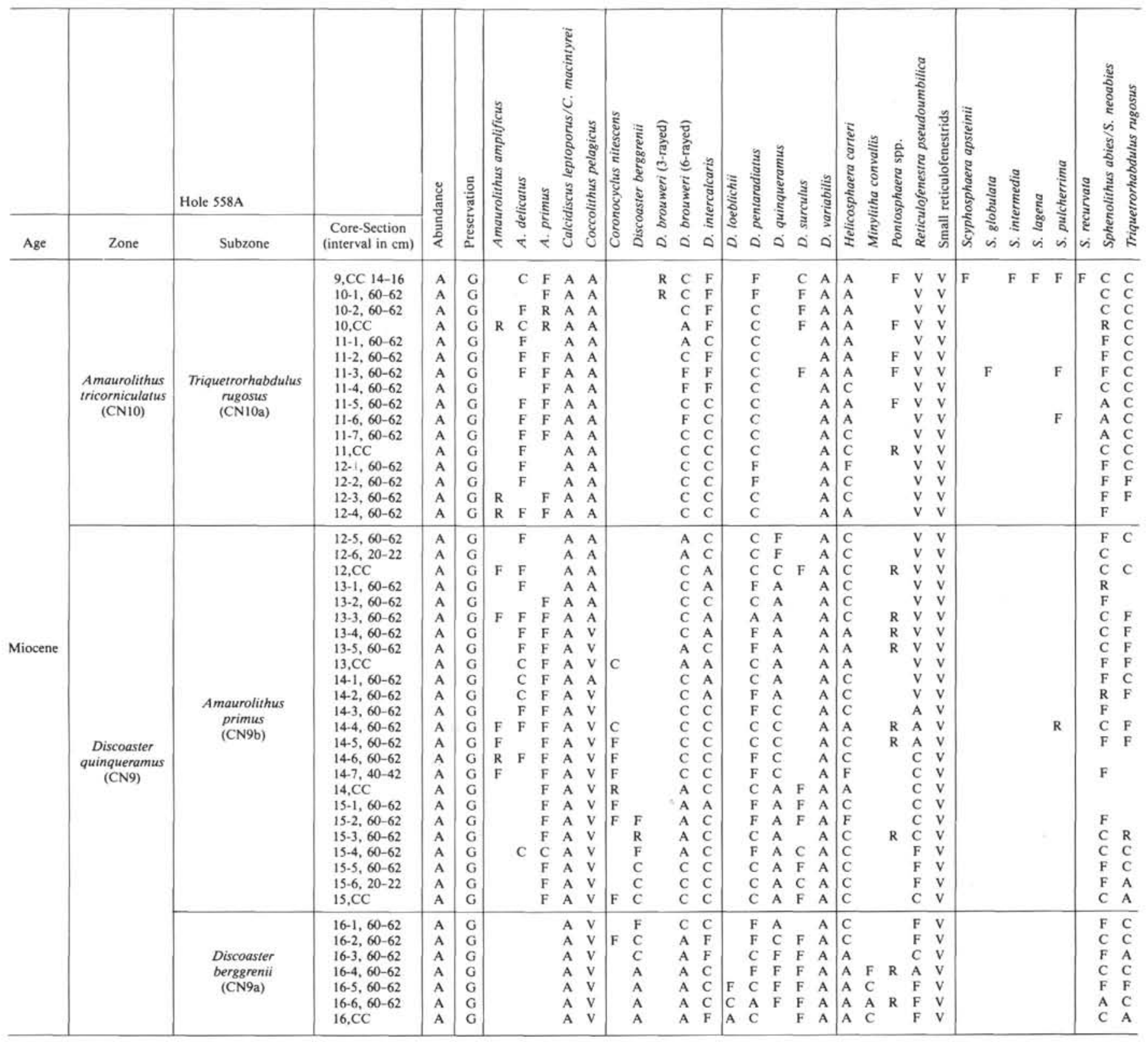

a plane passing through the middle of the holococcolith, so that two similar halves are formed (Gartner, 1967). These separated halves occur abundantly in this stratigraphic section. They are often broken and/or overgrown. Lanternithus minutus occurs abundantly in the $H$. reticulata Zone (CP16) and $Z$. bijugatus is abundant to very abundant. Because of their abundance, a few less heavily overgrown specimens can be found, and these confirm the identification of the more overgrown specimens. In addition, comparisons were made with other deep sea cores with similar holococcolith occurrences and in a similar state of preservation.

Bukry and Bramlette (1968) illustrated heavily calcified specimens of $P$. joidesa from JOIDES Blake Plateau cores that are very similar to specimens found in our North Atlantic section. They noted that rare, less calcified specimens indicate the identity of those heavily overgrown specimens. In Hole 563, specimens identified as $P$. joidesa are few to rare, occur sporadically, and are heavily overgrown. Consequently, identification of $P$. joidesa in this section is tentative. Broken and heavily overgrown fragments of discoasters may appear very similar to heavily overgrown specimens of $P$. joides $a$ and could be mistaken as such.

Samples 563-22,CC through 563-22-2, 52-54 cm are assigned to the Coccolithus formosus Subzone (CP16b) of the Helicosphaera reticulata Zone. Clausicoccus fenestratus occurs abundantly through $563-22-2,52-54 \mathrm{~cm}$, where the last $C$. formosus is found. This taxon, therefore, cannot be used to separate the $C$. formosus Subzone (CP16b) from the underlying subzone. Consequently, the lowermost samples in this hole may belong in the 
Table 3A. Distribution of calcareous nannofossils in Hole 563.

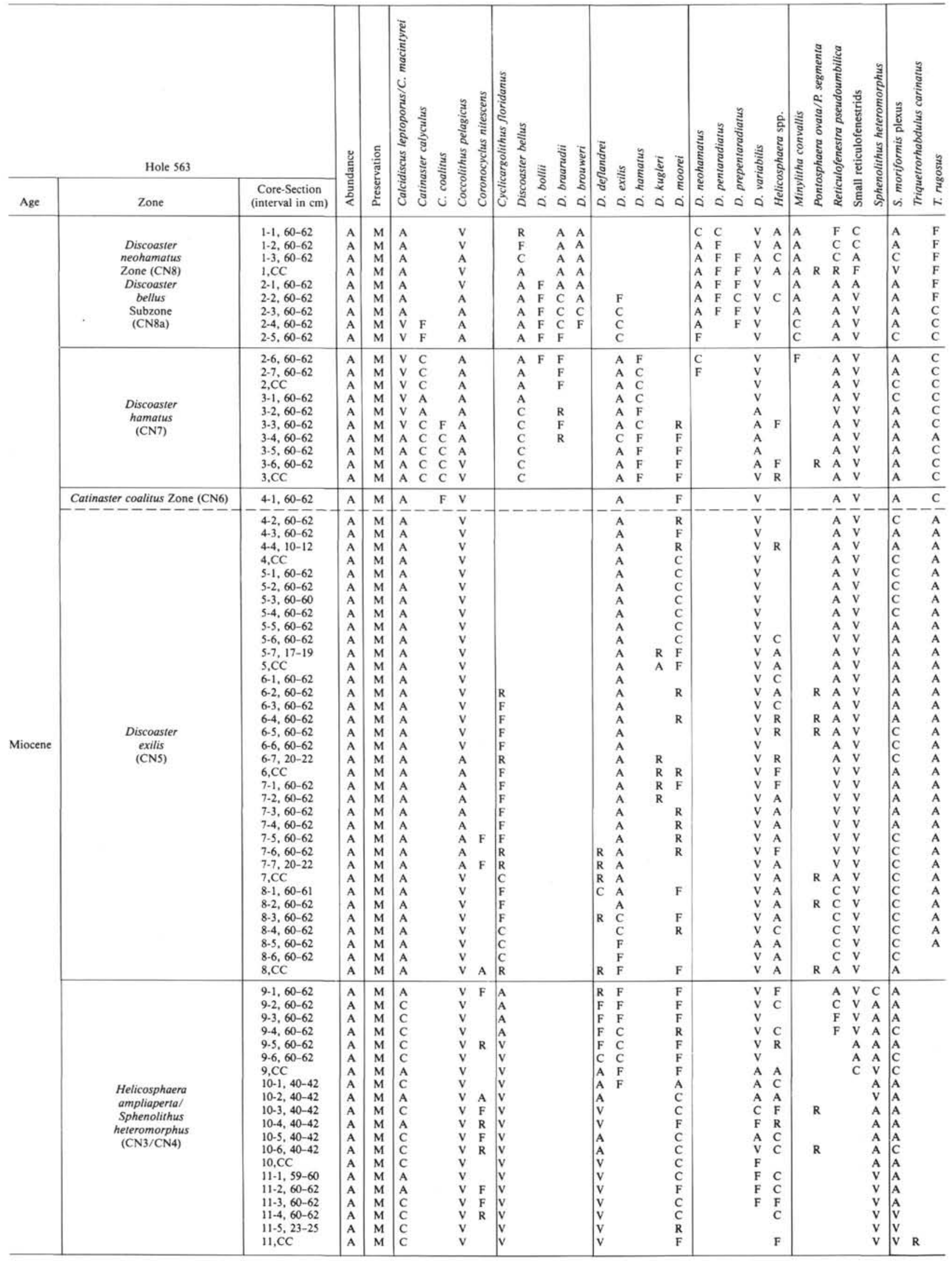


Table 3B. Distribution of calcareous nannofossils in Hole 563 .

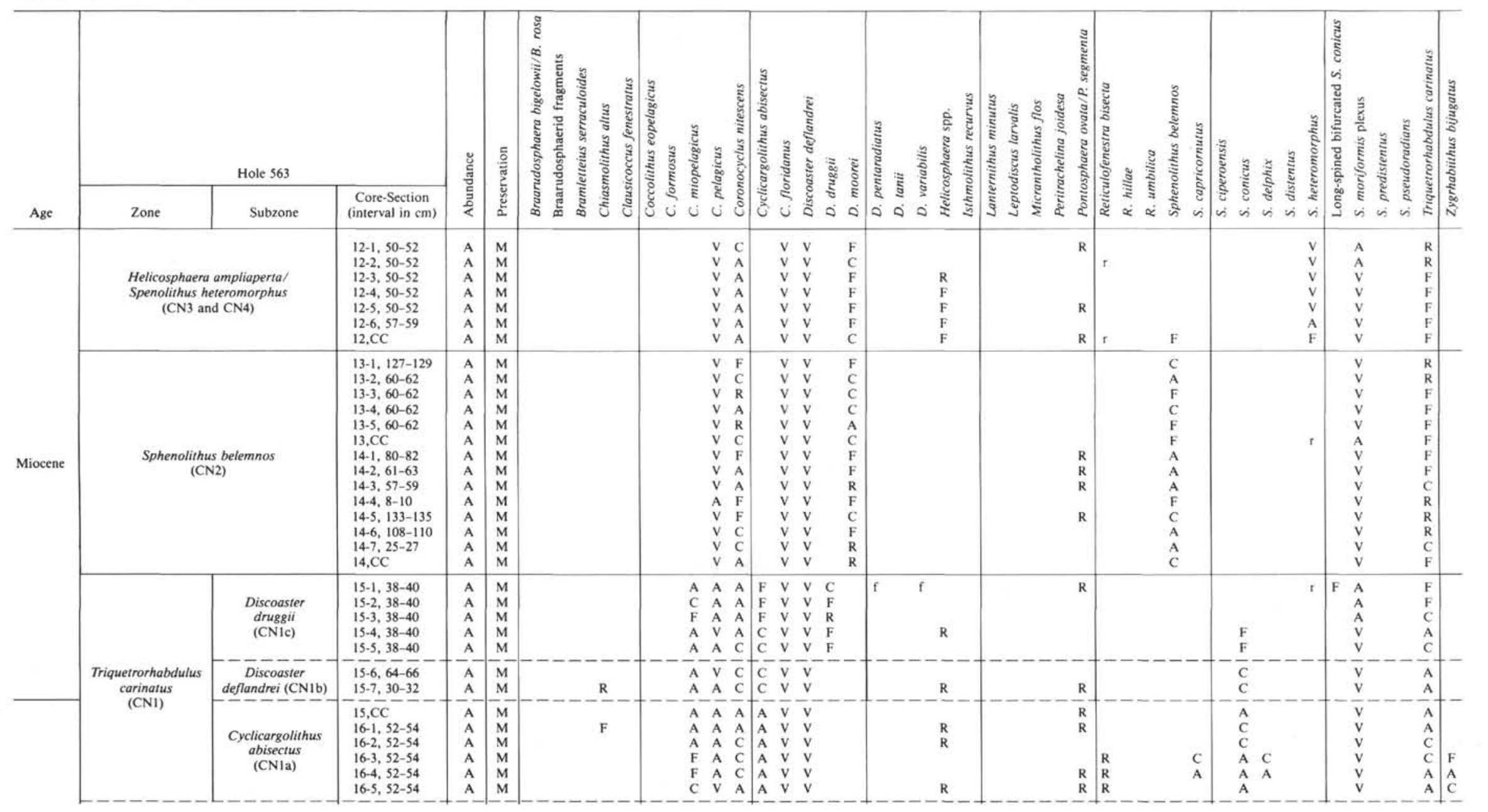




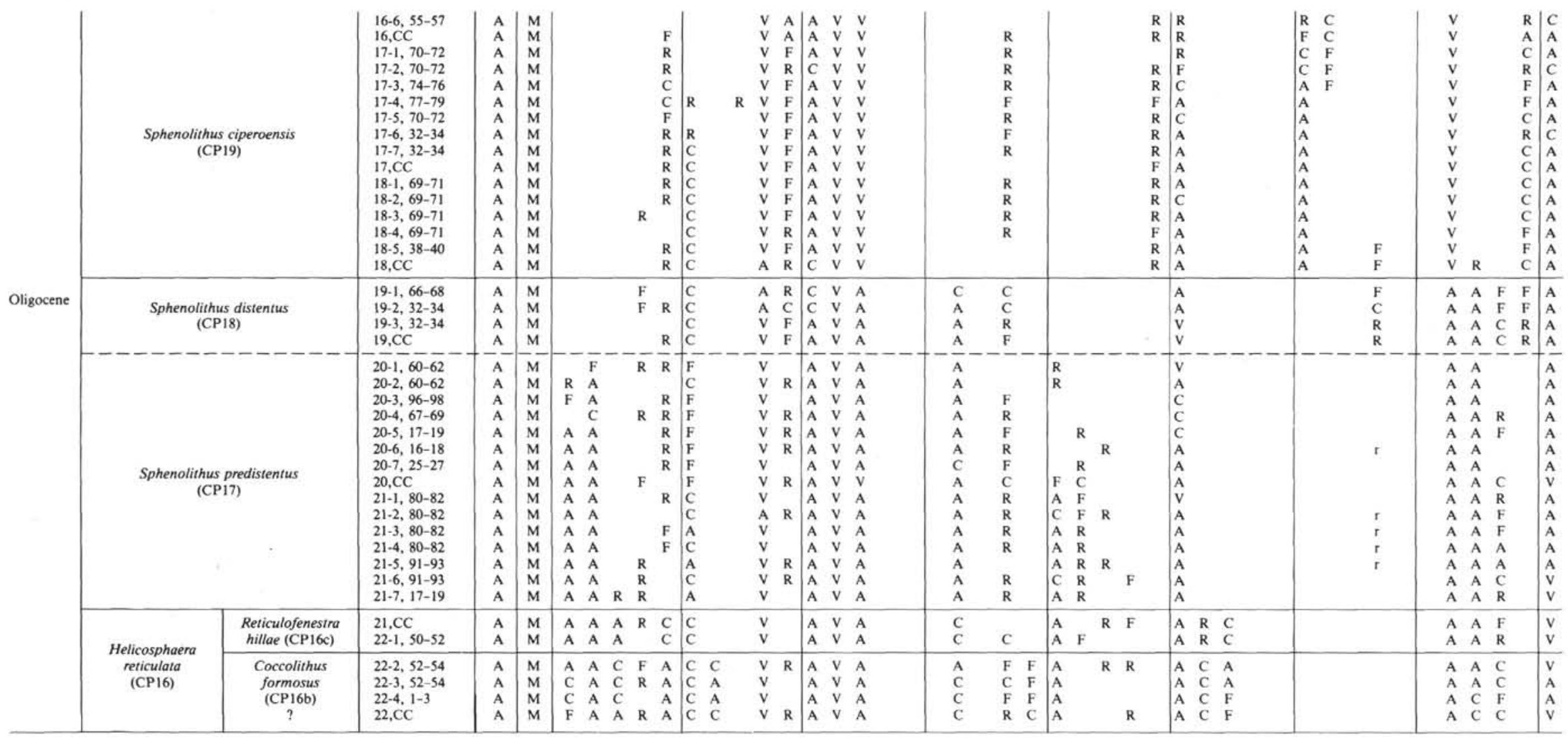




\begin{tabular}{|c|c|c|}
\hline Nannofossil species & Hole 558 & Hole 563 \\
\hline Peritrachelina joidesa & None & $\begin{array}{l}21-6 ; 21, C C \\
22-2 ; 22, C C\end{array}$ \\
\hline Lanternithus minutus & $25-3 / 26-4$ & $\begin{array}{c}20-1,20-2 \\
20, \mathrm{cc} / 22, \mathrm{CC}\end{array}$ \\
\hline $\begin{array}{c}\text { Braarudosphaera bigelowii/ } \\
\text { B. rosa }\end{array}$ & None & $\begin{array}{l}20-2,20-3 \\
20-5 / 22, \mathrm{CC}\end{array}$ \\
\hline Zygrhablithus bijugatus & $\begin{array}{c}17-1,17-2 \\
17, C C ; 18-3 \\
19-2 / 27-2\end{array}$ & $16-3 / 22, \mathrm{CC}$ \\
\hline
\end{tabular}

Figure 5. Occurrences of braarudosphaerids and holococcoliths in Holes 558 and 563. The highest and lowest sections are listed with a slash between them; single section occurrences are separated by a comma.

underlying $C$. subdistichus Subzone (CP16a). Samples 563-22-1, 50-52 cm and 563-21,CC lack C. formosus but do contain common $R$. umbilica and are placed in the Reticulofenestra hillae Subzone (CP16c).

It is difficult to distinguish the Sphenolithus predistentus Zone (CP17) from the Sphenolithus distentus Zone (CP18) in Hole 563 because of the rare and inconsistent occurrence of $S$. distentus. Rare specimens of $S$. distentus are found as low as Section 563-21-5. Sphenolithus distentus is never abundant and is common only in 563$19-2,32-34 \mathrm{~cm}$.

Bybell (1982) reported the first appearance of $S$. distentus in the $H$. reticulata Zone in Alabama, where it occurs with $C$. formosus and $R$. umbilica. She noted that Perch-Nielsen also found a co-occurrence of $R$. umbilica and $S$. distentus in Barbados.

Samples 563-21-7, 17-19 cm through 563-20-1, 60-62 $\mathrm{cm}$ are placed in the $S$. predistentus Zone (CP17). Rare occurrences of $S$. distentus in this interval are considered to be the result of downhole contamination. Braarudosphaerids are abundant throughout most of this interval, but they do decrease in numbers by $563-20-4$, 67-69 cm. Sample 563-20-1, 60-62 cm contains no intact braarudosphaerids and only a few disaggregated segments. Peritrachelina joidesa is found only in 563-21-6, 91-93 cm and the last abundant occurrence of L. minutus is in 563-21-1, 80-82 cm. Core 563-19 is placed in the $S$. distentus Zone (CP18) based on the consistent occurrence of S. distentus and the absence of Sphenolithus ciperoensis.

Samples 563-18,CC through 563-16-6, 55-57 cm are assigned to the upper Oligocene Sphenolithus ciperoensis Zone (CP19) based on the presence of S. ciperoensis. Bukry (1975) used the last occurrence of S. distentus to subdivide this zone. However, because of the inconsistency in the occurrence of $S$. distentus in this section, this zone is not subdivided. Sphenolithus ciperoensis is abundant throughout most of this zone. In Section 563-
16-6, however, $S$. ciperoensis is rare. Being both small in size $(4-6 \mu \mathrm{m})$ and rare, $S$. ciperoensis could easily be missed during smear-slide examination, so the upper zonal boundary is uncertain. Reticulofenestra bisecta, used by Bukry $(1973 b ; 1975)$ as an auxiliary marker, is rare from 563-17-1, through 563-16-6. Very rare specimens of $R$. bisecta are noted through 563-16-3. As in Hole $558, C$. fenestratus has a long range in Hole 563, with its last occurrence in 563-16, CC near the top of the $S$. ciperoensis Zone (CP19).

The Triquetrorhabdulus carinatus Zone (CN1) spans the Oligocene/Miocene boundary and is recognized in $563-16-5,52-54 \mathrm{~cm}$ through 563-15-1, 38-40 cm. Sphenoliths present in this zone include $S$. capricornutus, $S$. conicus, and $S$. delphix.

The Cyclicargolithus abisectus Subzone (CN1a) of the $T$. carinatus Zone is separated from the overlying subzone by the termination of the $C$. abisectus acme (Bukry, 1973b). In Hole 558, this acme could not be used to subdivide the T. carinatus Zone. In Hole 563, however, the end of the C. abisectus acme appears to be stratigraphically useful, and 563-16-5, 52-54 cm through 563$15, \mathrm{CC}$ are placed in the C. abisectus Subzone (CN1a). However, the reliability of this acme is still questionable, so the position of the upper subzonal boundary is uncertain and represented by a dashed line on the range chart.

Many discoasters may resemble $D$. druggii, especially when specimens are strongly overgrown as is the case here. Consequently, the boundary between the $D$. deflandrei (CN1b) and D. druggii (CN1c) Subzones is tentative in this section. Samples 563-15-7, 30-32 cm and $563-15-6,64-66 \mathrm{~cm}$ are assigned to the $D$. deflandrei Subzone (CN1b). Samples 563-15-5, 38-40 cm through $563-15-1,38-40 \mathrm{~cm}$ are placed in the $D$. druggii Subzone (CNlc).

Cores 563-13 and 563-14 are assigned to the lower Miocene Sphenolithus belemnos Zone (CN2). Sphenolithus belemnos and $S$. heteromorphus co-occur in Sample 563-12,CC. Bukry (1973b) noted the co-occurrence of these two species at DSDP Site 140 and stated that the first occurrence of the more cosmopolitan S. heteromorphus is considered the principal marker. Consequently, we use the first occurrence of $S$. heteromorphus instead of the last occurrence of $S$. belemnos to separate the $S$. belemnos Zone (CN2) from the overlying zone.

Both $S$. belemnos and $S$. heteromorphus are few in number in 563-12,CC and could represent a natural overlap. Alternatively, the co-occurrence of $S$. belemnos and $S$. heteromorphus in 563-12,CC could be the result of reworking or downhole contamination of the core-catcher. As pointed out by M. P. Aubry (personal communication, 1984), if one were to use Martini's (1971) zonation, a lower Miocene hiatus would be present between 563-12,CC and 563-13-1. As discussed for Hole 558 , we do not consider $T$. carinatus a very reliable marker in this moderately preserved section where $T$. carinatus is quite heavily overgrown and difficult to identify. Heavily overgrown $14-20 \mu \mathrm{m}$ rods, here attributed to $T$. carinatus, occur in small numbers through 563-11,CC. Therefore, we do not specifically delineate a lower Mio- 
cene hiatus. M. P. Aubry and K. G. Miller (personal communication, 1984), however, have informed us that they have additional evidence in the way of planktonic foraminiferal and magnetostratigraphic data that would allow them to place a hiatus between 563-12,CC and 56313-1. They would then attribute the co-occurrence of $S$. belemnos and $S$. heteromorphus to reworking at the unconformity.

As was the case at Site 558, the H. ampliaperta (CN3) and $S$. heteromorphus $(\mathrm{CN} 4)$ Zones are combined because we did not observe $H$. ampliaperta. Cores 563-9 through 563-12 are assigned to this interval. Sphenolithus heteromorphus is generally abundant to very abundant.

Discoaster variabilis first appears in 563-11-3, 60-62 $\mathrm{cm}$ and is very abundant by $563-10-6,40-42 \mathrm{~cm}$; Discoaster deflandrei is abundant in this sample. The end of the $D$. deflandrei acme is in 563-9-6, 60-62 cm. Therefore, as in Hole 558, different boundaries are obtained by the use of the first appearance of long-armed discoasters, the change in dominance among discoasters from $D$. deflandrei to long-armed discoasters, and the end of the $D$. deflandrei acme. In addition, discoaster abundances fluctuate considerably in Hole 563. Consequently, alternate datums are considered unreliable in this stratigraphic section.

The middle Miocene Discoaster exilis Zone (CN5) is recognized from 563-8,CC through 563-4-2, 60-62 cm. Discoaster kugleri, used by Bukry (1973b) to subdivide this zone, is abundant in 563-5, CC, but it occurs rarely and sporadically throughout the remainder of the zone. The last occurrence of Cyclicargolithus floridanus, used by Bukry (1975) as an auxiliary datum, is in 563-6-2, 60-62 cm. The last common occurrence of $C$. floridanus is in 563-7,CC. Because of the inconsistent and generally rare occurrence of $D$. kugleri, the principal datum, as well as the low abundance of $C$. floridanus throughout most of this zone, the Discoaster exilis Zone (CN5) is not subdivided.

Sample 563-4-1, 60-62 cm is placed in the Catinaster coalitus Zone (CN6). Preservation is moderate and $C$. coalitus is difficult to identify. Therefore, as in Hole 558, the lower zonal boundary is uncertain and dashed on the range chart.

Samples 563-3,CC through 563-2-6, 60-62 cm are assigned to the Discoaster hamatus Zone (CN7). Bukry's (1975) subdivision of this zone, based on the first evolutionary appearance of $C$. calyculus, cannot be used in this section because 563-3,CC contains both the first Catinaster calyculus and the first D. hamatus. Catinaster calyculus is common to abundant and D. hamatus is few to common throughout this interval. The first Discoaster bellus is found in the same sample as the first $D$. hamatus.

Samples 563-2-5, 60-62 cm through 563-1-1, 60-62 $\mathrm{cm}$ are placed in the Discoaster bellus Subzone (CN8a) of the Discoaster neohamatus Zone (CN8). Discoaster neohamatus is generally abundant throughout this interval. Some specimens of $D$. neohamatus are $24 \mu \mathrm{m}$ in diameter and have sharply bent rays.

\section{DISCUSSION AND CONCLUSIONS}

\section{Occurrence of Oligocene Braarudosphaera and Holococcoliths on the Mid-Atlantic Ridge}

The discovery of lower to mid-Oligocene Braarudosphaera-rich nannofossil chalk at the Mid-Atlantic Ridge (Site 563) was unexpected. This is the first report of such an assemblage from the mid-ocean environment of the North Atlantic, and it extends the known geographic occurrence of this flora considerably. Before considering the significance and implications of this finding, previous reports of Cenozoic braarudosphaerid-rich sediments will be reviewed briefly along with hypotheses concerning their origin.

It should be noted at the outset that the first discoveries of mid-ocean braarudosphaerid chalks (in the Oligocene of the South Atlantic; Maxwell, Von Herzen, et al., 1970) preceded the refinement of the calcareous nannofossil biostratigraphic zonal schemes used today, and that the nomenclature and occurrence datums of the two currently most widely used zonal schemes, those of Martini (1971) and Okada and Bukry (1980), differ in several respects in the critical upper Eocene-Oligocene interval. Before proceeding with literature review, therefore, it is important to note these differences so the reader will not become hopelessly confused when comparing the age determinations as given by various authors cited in the literature summarized here.

All current Oligocene coccolith zonal schemes are based on the zone boundaries outlined in a table by Bramlette and Wilcoxon (1967, table 2). Unique datum levels were not specified by these authors, so a choice was left to subsequent workers as to which of several possible first or last occurrence datums would be used to define each zone. Percival (in Maxwell, Von Herzen, et al., 1970), Martini (1971), and Bukry (1973a; 1973b) each chose slightly different criteria for their adopted zonations. The Martini and Bukry schemes are compared in Figure 6 , following the correlations indicated by Okada and Bukry (1980).

The important discrepancies to note in Figure 6 are (1) Martini (1971) subdivided Oligocene time into three subunits (early, middle, and late) whereas Okada and Bukry (1980) delineated two (early and late). The position of the latter boundary does not always appear in the literature at the same place relative to the Bukry zonal scheme (compare Okada and Bukry, 1980 with Haq, 1984, and Berggren et al., in press). (2) Martini (1971) and Okada and Bukry (1980) each number code their zone names, but with a different set of numbers for corresponding zones. (3) The two zonal schemes both use zonal names adopted from Bramlette and Wilcoxon (1967), but sometimes the same name applies to different intervals. For example, the Sphenolithus distentus Zone of Okada and Bukry (1980) corresponds to the upper portion of the Sphenolithus predistentus Zone of Martini (1971).

The upshot of this is that care must be taken to match zonal names and designations such as "early" and "late" used in the literature to the appropriate zonal scheme. 


\begin{tabular}{|c|c|c|c|c|c|c|}
\hline \multicolumn{2}{|c|}{$\begin{array}{l}\text { Age } \\
\text { NP CP }\end{array}$} & \multicolumn{2}{|c|}{$\begin{array}{c}\text { Zone name } \\
\text { (from Martini, 1971) }\end{array}$} & \multicolumn{3}{|c|}{$\begin{array}{l}\text { Zone and subzone names } \\
\text { (from Okada and Bukry, 1980) }\end{array}$} \\
\hline \multirow{7}{*}{ 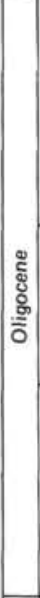 } & \multirow[b]{2}{*}{ 兽 } & $\begin{array}{c}\text { Triquetrorhabdulus } \\
\text { carinatus }\end{array}$ & $\begin{array}{c}\text { NN } \\
1\end{array}$ & $\begin{array}{c}\mathrm{CN} \\
\text { 1a }\end{array}$ & $\begin{array}{c}\text { Triquetrorhabdulus } \\
\text { carinatus }\end{array}$ & $\begin{array}{l}\text { Cyclicargolithus } \\
\text { abisectus }\end{array}$ \\
\hline & & $\begin{array}{l}\text { Sphenolithus } \\
\text { ciperoensis }\end{array}$ & $\begin{array}{l}\text { NP } \\
25\end{array}$ & $\begin{array}{l}\mathrm{CP} \\
19 \mathrm{~b}\end{array}$ & \multirow{2}{*}{$\begin{array}{l}\text { Sphenolithus } \\
\text { ciperoensis }\end{array}$} & $\begin{array}{l}\text { Dictyococcites } \\
\text { bisectus }\end{array}$ \\
\hline & - & $\begin{array}{l}\text { Sohenolithus } \\
\text { distentus }\end{array}$ & $\begin{array}{l}N P \\
24\end{array}$ & $\begin{array}{l}\mathrm{CP} \\
19 \mathrm{a}\end{array}$ & & $\begin{array}{l}\text { Cyclicargolithus } \\
\text { floridanus }\end{array}$ \\
\hline & & \multirow{2}{*}{$\begin{array}{l}\text { Sphenolithus } \\
\text { predistentus }\end{array}$} & \multirow{2}{*}{$\begin{array}{l}\text { NP } \\
23\end{array}$} & $\begin{array}{l}C P \\
18 \\
\end{array}$ & \multicolumn{2}{|c|}{ Sphenolithus distentus } \\
\hline & $\begin{array}{l}\frac{\Delta}{\bar{\tau}} \\
\frac{\bar{c}}{E}\end{array}$ & & & $\begin{array}{l}\mathrm{CP} \\
17 \\
\end{array}$ & Sphenolithus & redistentus \\
\hline & & $\begin{array}{l}\text { Helicosphaera } \\
\text { reticulata }\end{array}$ & $\begin{array}{l}\text { NP } \\
22\end{array}$ & $\begin{array}{l}\mathrm{CP} \\
16 \mathrm{c}\end{array}$ & \multirow{2}{*}{$\begin{array}{l}\text { Helicosphaera } \\
\text { reticulata }\end{array}$} & $\begin{array}{c}\text { Reticulofenestra } \\
\text { hillae }\end{array}$ \\
\hline & 窓 & $\begin{array}{c}\text { Ericsonia } \\
\text { subdisticha }\end{array}$ & $\begin{array}{l}\text { NP } \\
21\end{array}$ & \begin{tabular}{|c|} 
CP \\
16 \\
$a, b$
\end{tabular} & & $\begin{array}{l}\text { Coccolithus } \\
\text { formosus/ } \\
\text { Coccolithus } \\
\text { subdistichus }\end{array}$ \\
\hline \multirow{3}{*}{ 总 } & \multirow{3}{*}{ 苋 } & $\begin{array}{l}\text { Sphenolithus } \\
\text { radians }\end{array}$ & $\begin{array}{l}N P \\
20\end{array}$ & \multirow{2}{*}{$\begin{array}{l}\text { CP } \\
15 b\end{array}$} & \multirow{3}{*}{$\begin{array}{c}\text { Discoaster } \\
\text { barbadiensis }\end{array}$} & \multirow{2}{*}{$\begin{array}{l}\text { Isthmolithus } \\
\text { recurvus }\end{array}$} \\
\hline & & $\begin{array}{l}\text { Isthmolithus } \\
\text { recurvus }\end{array}$ & $\begin{array}{l}\text { NP } \\
19\end{array}$ & & & \\
\hline & & $\begin{array}{l}\text { Chiasmolithus } \\
\text { oamaruensis }\end{array}$ & $\begin{array}{l}\mathrm{NP} \\
18\end{array}$ & $\begin{array}{c}\mathrm{CP} \\
15 \mathrm{a}\end{array}$ & & $\begin{array}{l}\text { Chiasmolithus } \\
\text { oamaruensis }\end{array}$ \\
\hline
\end{tabular}

Figure 6. Comparison of the Martini (1971) upper Eocene-Oligocene zonation with that of Bukry, using correlations indicated by Okada and Bukry (1980).

In Figures 7 and 8 (backpocket), we have sought to compare the geographic occurrences of mid-Tertiary Braarudosphaera oozes, chalks, and Braarudosphaera/holococcolith associations cited in the literature for the Atlantic and Gulf of Mexico against the current Martini and Bukry calcareous nannofossil zonal schemes. The zonations are not correlated against linear time, although such a correlation could be made using the scheme of Berggren et al. (in press). With this explanation in mind, we can now return to our discussion.

A plot by Bukry (1970, fig. 1) of the distribution of Braarudosphaera holococcoliths based on early DSDP drilling in the North Atlantic indicated that these taxa were generally limited by ecological preference to nearshore pelagic environments. Discoveries of regionally restricted Tertiary braarudosphaerid-rich oozes and chalks in open ocean settings elsewhere in the world, therefore, have aroused considerable interest and speculation on the reasons for such occurrences. Attention has centered principally on Pliocene Braarudosphaera chalks from the western Pacific (Sites 236, 237, and 238; Roth, 1974), and on the Oligocene chalks and oozes encountered by several DSDP legs in the mid-latitudes of the South Atlantic (Legs 3, 39, 40, 73, and 74; Maxwell, Von Herzen, et al., 1970; Wise and Kelts, 1972; Supko, PerchNielsen, et al., 1978; Bolli, Ryan, et al., 1978; Noël and Melguen, 1978; Bukry, 1978a; LaBrecque et al., 1983; Hsü, LaBrecque, et al., 1984; Moore, Rabinowitz, et al., 1984).
Recently, additional note has been taken of the occurrence of Braarudosphaera/holococcolith associations of early Oligocene age in the Gulf of Mexico (Leg 77; Lang and Watkins, 1984). Another isolated occurrence of Braarudosphaera chalks has been reported by Bukry (1978a) at Oceanographer Canyon (Alvin-2698) in the western North Atlantic.

\section{Danian and South Atlantic Mid-Oligocene Occurrences}

A variety of hypotheses have been proposed to account for the occurrence of abundant braarudosphaerids over specific intervals of the Cenozoic record and at isolated localities in the world. Most of these center around the observation that modern Braarudosphaera are found most commonly in neritic environments along the margins of continents (Gran and Braarud, 1935; Smayda, 1966; Lefort, 1973), although they have been reported, usually in small numbers, from the open ocean as well (Gaarder, 1954; Hulbert, 1962; Hulbert and Rodman, 1963). A possible link to a benthic phase in the life cycle of the organism has also been suggested (Bybell and Gartner, 1972), although the inability to achieve longterm cultures of the modern organism (Lefort, 1972; Bukry, 1978a) has prevented documentation of its life cycle. The apparent correlation of the organism with a neritic habitat led to early suggestions that the mid-Oligocene accumulations in the South Atlantic, which consist of up to $98 \%$ Braarudosphaera, may have been displaced from shallower depths, a notion that was soon discarded as the aerial distribution and sedimentological characteristics of the deposits became better understood (see discussion by Wise and Kelts, 1972). Instead, enhanced productivity due to peculiar oceanographic conditions, the nature of which is unknown, is generally assumed to have been the direct cause for the anomalous accumulations. As Braarudosphaera is ranked as one of the most dissolution susceptible nannofossil genera (Bukry, 1970), their absence in deep sea sediments except during times of enhanced productivity (which would lower the calcium compensation depth for that organism) is generally attributed to dissolution (Wise and Kelts, 1972).

The traditional problem, therefore, has been to explain enhanced productivity, and for this, the various geological occurrences need to be considered separately. An extreme case is the blooms that occurred during the earliest Danian when Braarudosphaera served as an opportunistic "disaster form" that filled, where permitted, the vacant niches of an ocean nearly devoid of competing coccolithophorid species (Fischer and Arthur, 1977). These blooms have been noted in some but not all of the Cretaceous/Tertiary boundary sections on which detailed coccolith studies have been conducted (Perch-Nielsen et al., 1982), and it is not yet clear just what climatic or paleoenvironmental factors controlled their occurrences.

A second extreme case is the mid-Oligocene occurrences of the South Atlantic that lie in a relatively narrow band between 15 and $35^{\circ} \mathrm{S}$ (Figs. 7-10). In that band, Braarudosphaera constitute up to $90-98 \%$ of the sediment and occur in beds up to a meter or more in thick- 


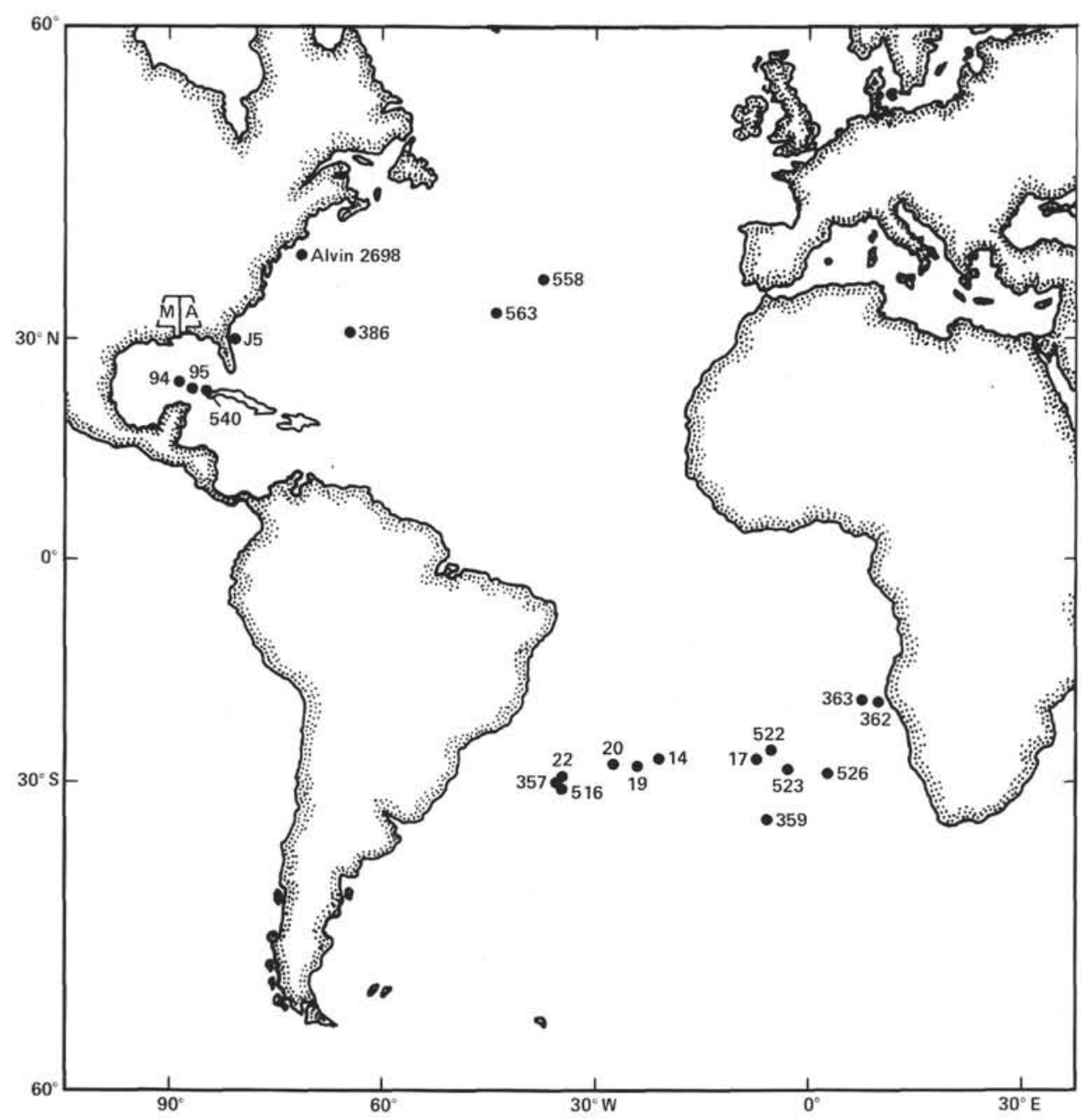

Figure 7. Location map for DSDP and other ocean or land outcrop sites at which braarudosphaerid ooze/ chalk or braarudosphaerid/holococcolith associations have been reported from the upper Eocene-Oligocene. $\mathbf{M}=$ Mississippi; $\mathbf{A}=$ Alabama.

ness (Maxwell, Von Herzen, et al., 1970; Bolli, Ryan, et al., 1978). At Site 362, the occurrences are cyclical with as many as 34 Braarudosphaera chalk beds recorded in the section (Bukry, 1978a). Observing that the greatest modern concentrations of Braarudosphaera are found in the areas of reduced ocean salinities (high coastal runoff or upwelled water), Bukry (1978a) sought some mechanism that would have produced a short term lowering of near-surface water salinities, such as abnormally high regional rainfall (Bukry, 1974) or periodic influxes of glacial meltwaters from the Oligocene polar ice cap (personal communication from K. J. Hsü to D. Bukry, 1978). Similarly, Bolli, Ryan, et al. (1978) postulated high freshwater influx from the Orange River during the Oligocene, coupled with upwelling of nutrient-rich intermediate or deep low-salinity water to explain Braarudosphaera oozes in the Cape Basin. Considering the wide distribution of the deposits across the South Atlantic, Berger (1979) hypothesized that the blooms may represent mid-ocean upwelling.

In a recent discussion of the South Atlantic occurrences, LaBrecque et al. (1983) determined that the most prominent Braarudosphaera chalk layer at Sites 522 and 523 was deposited within the Oligocene magnetostratigraphic interval C10.18R to C10.35R (NP23 of Martini, 1971) with a second, although minor, occurrence in the lower Oligocene at C12.63R (NP22) of Hole 522B. They noted that the first zone correlates with an abrupt decrease in the eustatic sea level curve of Vail et al. (1977) and falls within the time of the opening of Drake Passage postulated by LaBrecque and Rabinowitz (1977) (early to mid-Oligocene magnetic Anomaly 10-13 time as opposed to the late Oligocene magnetic Anomaly 8 time as proposed by Barker and Burrell, 1977). LaBrecque et al. (1983) then concluded that the opening of Drake Passage and subsequent atmospheric instabilities because of the initiation of circum-Antarctic winds and strong latitudinal temperature gradients could have caused enhanced circulation within the South Atlantic and, consequently, the mid-ocean upwelling postulated by Berger (1979).

Regardless of whether a connection with the opening of Drake Passage can be firmly established, the hypothesis of mid-ocean upwelling is an attractive one. Braaru- 


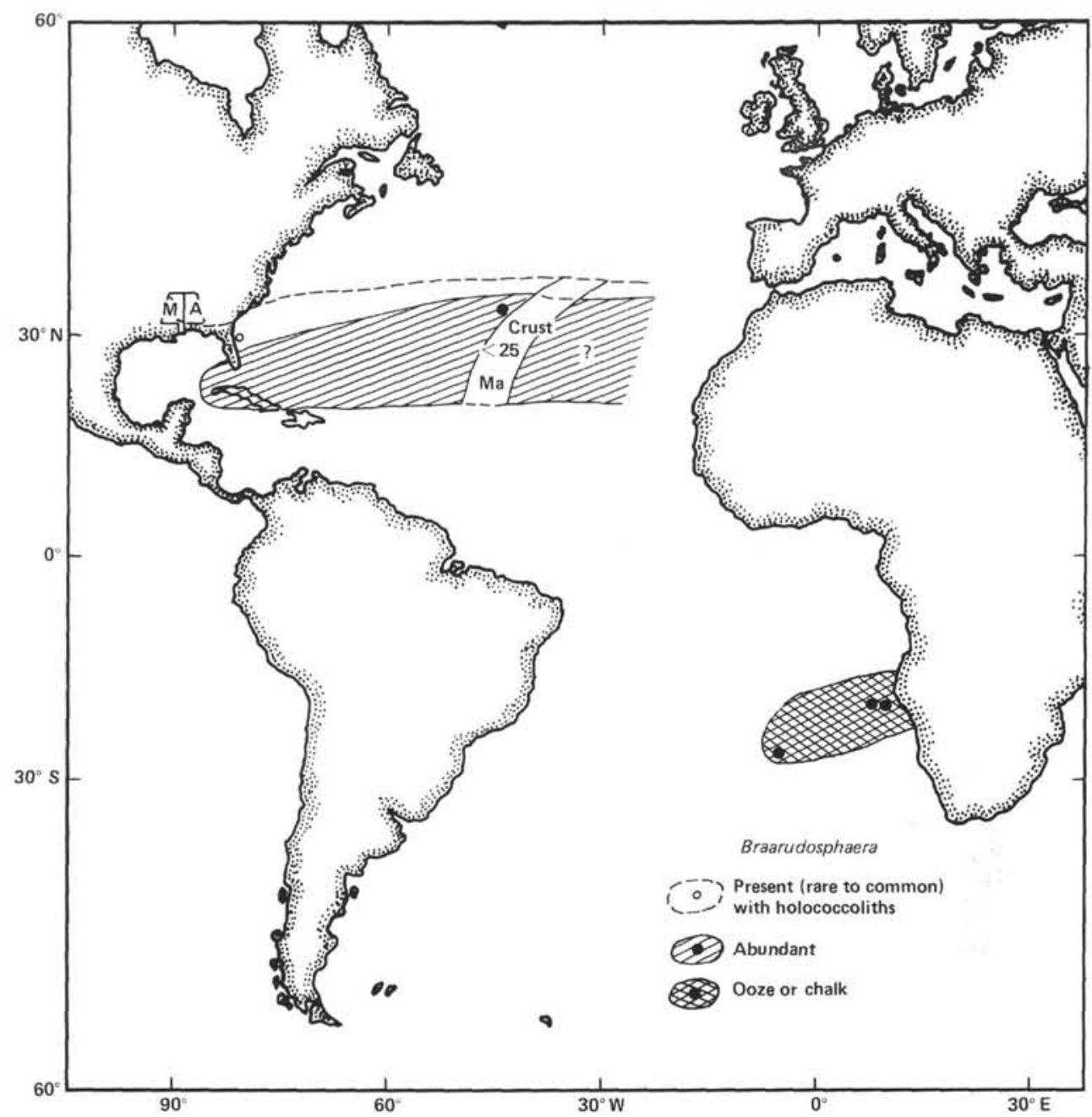

Figure 9. Map of reported Braarudosphaera oozes, chalks, and Braarudosphaera/holococcolith associations during NP22 (CP16c) time.

dosphaerid blooms first appeared off Africa during NP22 time (Figs. 8 [backpocket] and 9), extended across the South Atlantic to the Rio Grande Rise during NP23 (Figs. 8 [backpocket] and 10), and then continued to persist off Africa (DSDP Sites 262 and 263) during NP24. The persistence of the blooms at the two sites just off Africa could be attributed to upwelling associated with a northward flowing surface current whose velocity had increased, as suggested by LaBrecque et al. (1983), and/ or whose flow had been perturbed by submarine features along the eastern Walvis Ridge, which would have been shallower than today.

The expansion of upwelling conditions across the entire South Atlantic over deep as well as shallow sites during NP23, however, would have required more than a local perturbation, but rather some form of large-scale divergence. In addition, the quality of the upwelled water should have been such that calcareous phytoplankton were favored over siliceous forms, and predominantly one taxon (Braarudosphaera) at that. Modern analogs for such a phenomenon, of course, are hard to find. Recently, however, special oceanographic conditions creating a modern day divergence and mid-ocean upwelling at comparable latitudes $\left(30-31^{\circ} \mathrm{S}\right)$ in the South Pacific have been documented by deep sea drilling off New Zealand (Leg 90, Kennett, von der Borch, et al., 1983). Upwelling along the poorly known Subtropical Divergence (Tasman Front) has apparently resulted in enhanced productivity of calcareous nannoplankton rather than of siliceous organisms throughout the Neogene. No abnormal species diversity, however, was reported. Therefore, the analogy with braarudosphaerid blooms in the Oligocene of the South Atlantic breaks down at that point. However, exceptionally low (or high?) surface salinities in the South Atlantic Oligocene, as often suggested, could have served as a filter by which production of Braarudosphae$r a$ was enhanced at the expense of other coccolith taxa.

\section{Other Oligocene Occurrences}

The pattern of occurrence of Braarudosphaera elsewhere during the early to mid-Oligocene may have been somewhat less unusual than either of the two more extreme situations discussed above. These other Oligocene occurrences seem to be a continuation of a pattern that developed during the late Eocene or before. The association of Braarudosphaera (and the closely related gen- 


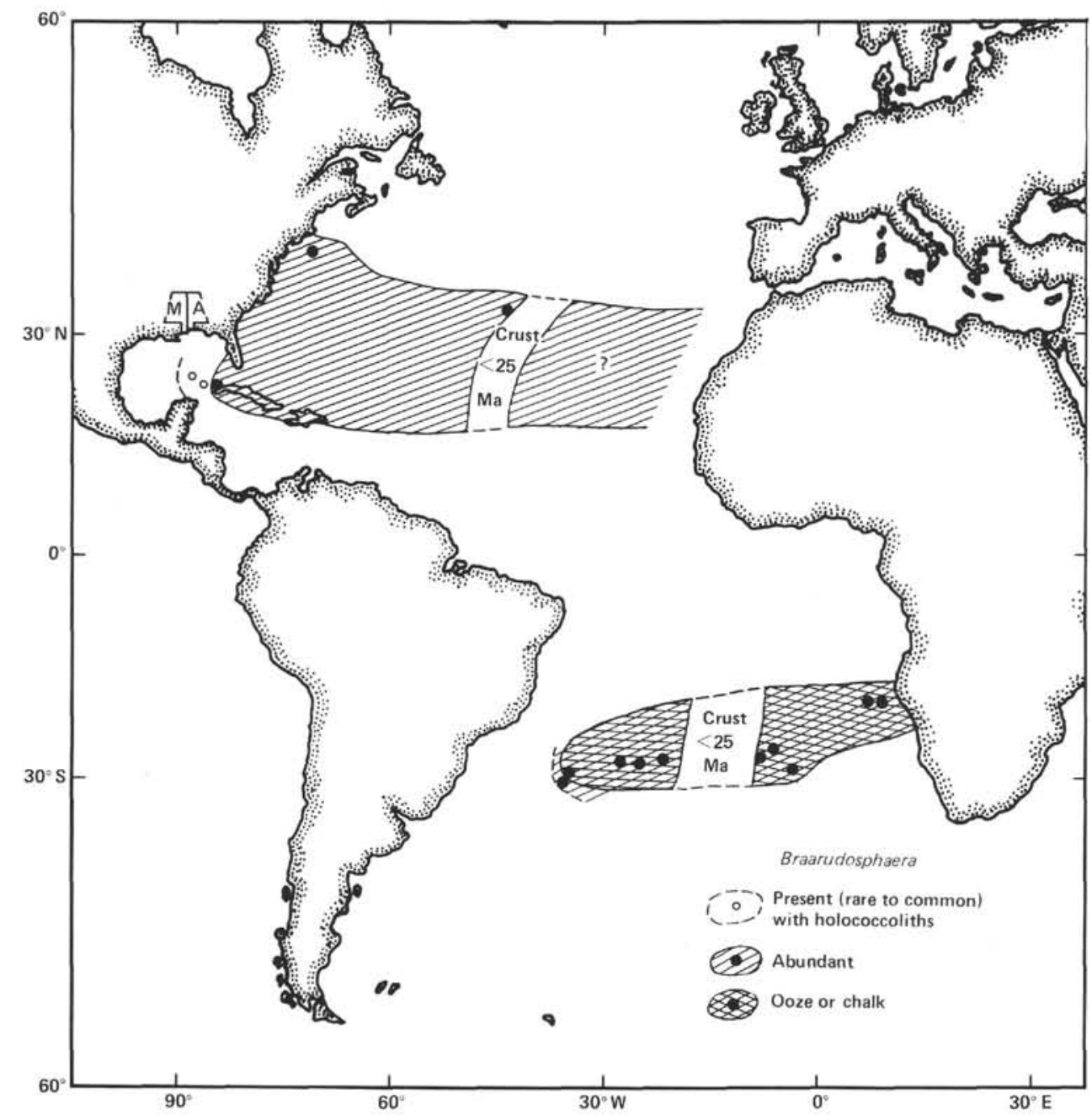

Figure 10. Map of reported Braarudosphaera oozes, chalks, and Braarudosphaera/holococcolith associations during NP23 (CP17/18) time.

era Micrantholithus and Pemma) with the holococcoliths Lanternithus minutus, Peritrachelina joidesa, and Zygrhablithus bijugatus ${ }^{3}$, among others, has been noted for low to mid-latitude nearshore shelf to bathyal paleoenvironments of the upper Eocene at a number of localities (Fig. 8). In many instances, particularly in and around the Gulf of Mexico, these occurrences continue with little change into the lower Oligocene. These upper Eocene to lower and mid-Oligocene examples differ from the mid-Oligocene occurrences of the South Atlantic in that the braarudosphaerids never reach the overwhelming numbers ( 90 to $98 \%$ ) reported for the latter. Instead percentages of whole and fragmented braarudosphaerid particles of up to 5 to $10 \%$ of the total sediment are more the norm for the peak Oligocene occurrences in the Northern Hemisphere.

An interesting comparison for the Leg 82 mid-ocean accumulations is provided by those recently reported from Site 540 in the southeastern Gulf of Mexico (lat. $23^{\circ} \mathrm{N}$,

\footnotetext{
${ }^{3} \mathrm{Z}$. bijugatus is not plotted in Figure 8 (backpocket) because this most ubiquitous of the holococcolith species occurs in abundance at all but the deepest ocean sites.
}

long. $84^{\circ} \mathrm{W}$; Lang and Watkins, 1984). This site, just over $100 \mathrm{~km}$ north of Cuba, lies at bathyal depths in $2926 \mathrm{~m}$ of water. Although the tectonic history of the site is not well known, there is no independent evidence to suggest that it was significantly shallower in the Oligocene than today. Lang and Watkins (1984) noted that the occurrence of braarudosphaerids in Sections 540-22-1 to 540-28-2 spans the upper Eocene to lower-middle Oligocene. Their numbers fluctuate between common and abundant throughout the interval, but they are only few to rare in the sections above and below. The holococcoliths Peritrachelina joidesa, Lanternithus minutus, and Zygrhablithus bijugatus are also present and their abundances seem to parallel those of the braarudosphaerids, particularly in the case of Peritrachelina joidesa. Lang and Watkins (1984) considered three possible mechanisms for the anomalous accumulation of the assemblages: (1) shallowing of the seaway, (2) selective dissolution of other nannofossil species, and (3) an increase in their productivity. They considered the first two possibilities unlikely, concluding, as have many previous workers, that the cause of the accumulations and the fluctuations in their abundances reflect changes in productivi- 
ty, the causes for which are obscure. They noted that in modern environments Braarudosphaera can tolerate both decreased (Roth, 1974) and elevated (Martini, 1967) salinities better than most other species, and that either of these extremes or a fluctuating salinity could have enhanced their productivity at Site 540 .

\section{Occurrences at Site 563}

The most striking aspect of the mid-ocean occurrence of abundant braarudosphaerids at the North Atlantic Leg 82 site, Site 563 , is that it falls within the mid-latitudes. Together with other known occurrences closer to the margins of the North American continent or near the island of Bermuda, they form a mirror image of the mid-latitude occurrences of the South Atlantic (roughly bracketed today between 15 and $40^{\circ} \mathrm{S}$ ). Their absence at intervening sites in the Caribbean and the equatorial Atlantic produces an apparent bipolar distribution (Figs. 9 and 10) that suggests some type of zonal climatic control for this pattern. Bipolar distribution patterns for certain species are not uncommon among coccolith assemblages (McIntyre and Bé, 1967; Thierstein, 1981), however, and only denote a general ecological preference based on temperature. Beyond that correlation, the specific accumulations of braarudosphaerids and holococcoliths in the Atlantic require more detailed analysis and alternative explanations can be considered as well.

Among the Leg 82 sites, braarudosphaerids are present essentially only at Site 563. As sediments of apparently the same age were cored at both Sites 563 and 558, several mechanisms can be considered that might explain their essential absence at the northern site, namely: (1) erosion or nondeposition of braarudosphaerid bearing sediments at Site 558; (2) different Oligocene paleodepths (i.e., Site 563 was shallower than Site 558); (3) presence of some emergent land mass or island fostering the accumulation of neritic species near Site 563 but not near Site 558; and (4) ecologic exclusion based on temperature as discussed above.

The first possibility, that the braarudosphaerid inter$\mathrm{val}$ at the northern site is missing due to erosion or nondeposition, seems unlikely because (1) no hiatuses were noted in the lower Oligocene section at Site 558, and (2) the Oligocene coccolith zones (CP16 and CP17) are of nearly equal thickness at both sites (Fig. 4).

The second possibility presupposes some major difference in paleobathymetry of the two sites that would cause the basement underlying Site 563 to form or remain at a shallower water depth during the early to midOligocene. This, in turn, would enhance the chances that the relatively soluble braarudosphaerids would be preserved at the "shallower" site whereas they could have been destroyed by dissolution at the "deeper" site. This possibility is further suggested by the fact that the two sites are quite some distance apart $(400 \mathrm{~km})$ and are separated by two well-defined fracture zones (Fig. 1). The topography along mid-ocean ridges today is not uniform (Sclater et al., 1971), and it would be rather coincidental if the sites did actually lie at the same approximate water depth when the ocean crust beneath them was first generated. In addition, the crust on opposite sides of fracture zones often lies at different bathymetries, thus the two sites could conceivably have experienced somewhat different spreading histories resulting in different bathymetries during the course of seafloor spreading.

A simple way to evaluate the possibility of different bathymetric histories is to note the present depths of the Oligocene strata overlying basement today. At Site 558, the basal Oligocene stratum lies at $4175 \mathrm{~m}$ below the sea surface, whereas at Site 563 it lies at $4160.5 \mathrm{~m}$. These values are surprisingly close to one another and would represent a remarkable coincidence if the two sites had experienced significantly different bathymetric histories. It would mean that the crust at Site 563 would have been at a significantly higher elevation during the early Oligocene, but subsequently it would have to have subsided much more rapidly to reach a present day depth only slightly shallower than that at Site 558. This seems highly unlikely.

The possibility that the deposition of braarudosphaerids at Site 563 was influenced by an emergent land mass or a nearby set of islands requires an examination of the ocean bathymetry not just around that site but along the conjugate magnetic anomaly on the opposite side of the Mid-Atlantic Ridge as well. The only obvious feature, in addition to the present day Azores, is a set of small seamounts just south of the Azores. These, however, would backtrack closer to Site 558 than to Site 563 . Hence their possible influence on Site 563 can be eliminated.

The last possibility considered, that of ecologic exclusion based on temperature, assumes that the latitudinal distance of about $4^{\circ}$ separating the two sites is significant. Whereas this may seem a trivial distance at first glance, it may well be important considering that the northern site, Site 558, lies close to the northern limit at which abundant Oligocene braarudopshaerids have been reported along the North American continental margin (Oceanographer Canyon; Bukry, 1978a). Because of other factors such as local warm surface currents (perhaps some type of proto-Gulf Stream), upwelling conditions, or differences in bathymetry, the northern limits of the distribution of abundant Braarudosphaera in the open ocean may have been somewhat less than along the continental margin at this time. In contrast to the braarudosphaerids, it is interesting to note that the holococcoliths were generally well represented at both sites, indicating that their abundance was not as restricted by temperature as were the braarudosphaerids. The only exception is Peritrachelina joidesa which occurred infrequently at the southern site and was not detected at all at the northern one (Fig. 5).

Taking all of the above into consideration, we believe the last possibility considered, that of ecologic (temperature) exclusion, to be the most probable explanation for the abundant accumulations of braarudosphaerids at Site 563 and their virtual absence at Site 558. In retrospect, it is regrettable that basal Oligocene sediments could not have been cored at the other sites drilled by Leg 82 on or near magnetic Anomaly 13 (Sites 556, 559, and 564). This would have provided far better evidence 
of the bathymetric histories of the various sites as well as more accurate information on the distribution of braarudosphaerids in the region.

The occurrence of braarudosphaerids and the holococcoliths in question on the Mid-Atlantic Ridge, however, provides one rather important parameter concerning their distribution. It provides a minimum depth above which one can reasonably except the forms to be preserved in sediment deposited within the geographic range of the organisms during the late Eocene-Oligocene. Assuming an average elevation of newly formed crust to be $2700 \mathrm{~m}$ (Sclater et al., 1971), one can accept that depth or one slightly greater as a working value for this parameter.

Although braarudosphaerids are common at Site 563, as noted previously, they never reach the overwhelming abundant proportions seen in the mid-Oligocene of the South Atlantic. Instead, their numbers are more in line with those deposited in localities closer to the continental margins during the late Eocene and early to mid-Oligocene. It is reasonable, therefore, to assume that rather extraordinary and different conditions caused the anomalous occurrences in the mid-Oligocene South Atlantic as opposed to elsewhere in the world. Oligocene occurrences elsewhere are more pervasive on a global scale and may be the norm for the upper Eocene-lower Oligocene within their range of distribution, limited otherwise by paleo-water depth (generally near or above $3000 \mathrm{~m}$ ) and nutrient supply. Although a rough bipolar temperatesubtropical distribution marking their maximum abundance seems to be emerging (Figs. 9 and 10), the data are still sketchy and not totally convincing. Each Oligocene drill site and land section locality still needs to be analyzed in detail with respect to paleobathymetry and the presence of other coccolith species before a total picture can be drawn. On the other hand, the broader question of the reason for the generally high occurrence of braarudosphaerids during the late Eocene to mid-Oligocene in both nearshore and open ocean environments, from which the living stock for the extraordinary blooms of the South Atlantic mid-Oligocene was derived, is a broader question that is not addressed here. The fact that abundant open ocean occurrences were confined largely to the Eocene-Oligocene interval suggests the existence of peculiar paleo-oceanographic/paleoclimatic conditions not in existence before or since. Interestingly, this time interval was a critical transitional period in the evolution of Cenozoic climates, one in which global climates were deteriorating and in which the psychrosphere developed (Kennett, 1978).

\section{PLIOCENE/PLEISTOCENE BOUNDARY STRATIGRAPHY}

Takayama (1970) observed frequent 3-rayed forms of D. brouweri near the Pliocene/Pleistocene boundary in his study of the Le Castella section in Italy. Haq et al. (1977) noted the presence of reworked discoasters of early and late Tertiary age throughout the Pliocene/Pleistocene boundary stratotype section at Le Castella. They used an increase in the relative abundance of the 3-rayed variety of $D$. brouweri as an indicator of the LAD (last appearance datum) of $D$. brouweri. Above this level, Haq et al. (1977) found that $D$. brouweri (6-rayed) decreased abruptly in abundance. Backman et al. (1983) also used an increase in the relative abundance of triradiate forms as an indicator of the position of the Pliocene/Pleistocene boundary in their work on the Vrica section of Italy.

Rio (1982) reported the simultaneous extinction of the two varieties of $D$. brouweri from Sites 125 and 132 in the Mediterranean, Site 502 in the Caribbean, and from the Capo Rosella section of Sicily. Backman and Shackleton (1983) applied quantitative methods in order to improve the biostratigraphic resolution of Pliocene and early Pleistocene calcareous nannofossil extinction events in sediments from low and middle latitudes of the Pacific, Atlantic, and Indian oceans. In Pacific, Atlantic, and Indian ocean cores, regardless of latitudinal position of the cores, they found that the triradiate form of $D$. brouweri increases in proportion relative to the 6-rayed form between the Olduvai and the Gauss, shortly before their simultaneous extinction.

Backman and Shackleton (1983) concluded that this increase is a global phenomenon and a valuable guide for proximity to the extinction level of the species. The proportion of the triradiate form of $D$. brouweri showed no prominent peak other than that near the end of its range. The duration of the interval during which the triradiate form is relatively abundant was estimated by Backman and Shackleton (1983) to be between 0.10 and 0.15 $\mathrm{Ma}$. Therefore, even in sections having considerable reworking, this triradiate signal may be biostratigraphically useful, because there is no older potential source from which the 3-rayed forms of $D$. brouweri may be reworked in sufficient numbers to imitate this peak.

In summary, the quantitative work of Backman and Shackleton (1983) established two biostratigraphically important relationships between the 6-rayed and 3-rayed forms of $D$. brouweri. First, the two forms have simultaneous extinctions. Secondly, the proportion of 3-rayed $D$. brouweri increases relative to 6-rayed forms of $D$. brouweri from values less than $10 \%$ to values in excess of $20 \%$ shortly before their joint extinction.

These relationships may be applied to the section at Hole 558A, which shows substantial reworking. The LAD of D. brouweri and the position of the Pliocene/ Pleistocene boundary thus determined would be at the top of 558A-7-2, 70-71 cm. This sample contains abundant 3-rayed and 6-rayed $D$. brouweri, and above this sample 6-rayed forms of $D$. brouweri are few to rare and 3 -rayed forms are absent. This section is problematic in that this sample also marks the final appearance of $\mathrm{Cal}$ cidiscus macintyrei. Backman and Shackleton (1983) concluded that the extinction of $C$. macintyrei represents a reliable global datum event that should occur at approximately $1.45 \mathrm{Ma}$, above the LAD of $D$. brouweri.

One possible explanation for the nannofossil occurrences observed in Hole 558A is that a short hiatus is present and the C. macintyrei Zone of Gartner (1977) is absent. A length of $0.14 \mathrm{Ma}$ was given by Gartner (1977) for the duration of the $C$. macintyrei Zone. The existence of such a short hiatus would be difficult to prove, 
however. In 558A-7-4, 70-71 cm, triradiate forms of $D$. brouweri are common; triradiate forms are rare in lower samples. Although samples above 558A-7-4 contain common to abundant $D$. brouweri, the $C$. macintyrei Zone, if present, may begin in Section 558A-7-3. Therefore, zonal boundaries are uncertain, and although the most probable position for the Pliocene/Pleistocene boundary is above 558A-7-2 with the presence of a hiatus likely, no hiatus is delineated on the range chart. More closely spaced samples through this interval were not available for this study, but such sampling might well resolve the problem.

Although the exact position of the Pliocene/Pleistocene boundary is questionable in Hole $558 \mathrm{~A}$, the increased abundance of triradiate forms of $D$. brouweri provides a valuable signal for proximity to that boundary, particularly in view of the reworking of $D$. brouweri in the section.

\section{SUMMARY}

A detailed study of the abundance, preservation, and biostratigraphic distribution of calcareous nannofossils at Sites 558 and 563 shows that only one hiatus (early Pliocene) is present in these sections. Subzones CN10b, $\mathrm{CN} 10 \mathrm{c}$, and $\mathrm{CN} 1 \mathrm{a}$ are missing. In the uppermost Pliocene of Hole 558A, a peak in the relative abundance of 3-rayed Discoaster brouweri, followed by the absence of 3 -rayed forms in overlying sections, provides a useful guide for the placement of the Pliocene/Pleistocene boundary where the extinction of 6-rayed $D$. brouweri has been obscured by reworking.

The most unexpected element of the nannofossil assemblages was the presence in Cores 563-20 through 563-22 of abundant braarudosphaerids, along with the holococcoliths Lanternithus minutus, Peritrachelina joidesa, and Zygrhablithus bijugatus. This is the first report of abundant lower Oligocene braarudosphaerids and this suite of holococcoliths from the central North Atlantic. Braarudosphaerids are absent in Hole 558, located approximately $400 \mathrm{~km}$ to the north. The sediments of the two holes are of the same age and were deposited at similar water depths. The absence of braarudosphaerids in Hole 558 is attributed to the crossing of a latitudinal (temperature dependent) provincial nannofossil boundary.

\section{ACKNOWLEDGMENTS}

This paper was derived from a master's thesis (Parker, 1984) submitted to the Department of Geology, Florida State University.

We thank William I. Miller III for his skillful operation of the SEM, Kim Riddle for the printing of the micrographs, Dennis Cassidy for the use of the Antarctic core facilities, and Sharon Reeves and Jill Arnold for typing the manuscript. We thank David K. Watkins and James A. Bergen (both at FSU) for their critical reviews of the manuscript and invaluable assistance throughout the research phase. The penultimate draft was critically reviewed by Marie-Pierre Aubry (Woods Hole Oceanographic Institution), Kenneth G. Miller (Lamont-Doherty Geologic Observatory), and Jay Bowdler (Union Oil Company of California, Houston). Dr. Aubry, who had examined some of the sections, made many helpful comments and suggested alternative means for zoning the sequences. Laboratory facilities for this research were supported by NSF grants DPP 8020382 and EAR 8025489 .

\section{REFERENCES}

Aumento, F., Melson, W. G., et al., 1977. Init. Repts. DSDP, 37: Washington (U.S. Govt. Printing Office).

Backman, J., 1979. Pliocene biostratigraphy of DSDP Sites 111 and 116 from the North Atlantic Ocean and the age of Northern Hemisphere glaciation. Stockholm Contrib. Geol., 32:115-137.

Backman, J., and Shackleton, N. J., 1983. Quantitative biochronology of Pliocene and early Pleistocene calcareous nannofossils from the Atlantic, Indian and Pacific oceans. Mar. Micropaleontol., 8: 141-170.

Backman, J., Shackleton, N. J., and Tauxe, L., 1983. The PliocenePleistocene at the Vrica section: quantitative nannofossil correlation to the deep sea. Nature, 304:156-158.

Barker, P. F., and Burrell, J., 1977. The opening of Drake Passage. Mar. Geol., 25:25-34.

Barker, P. F., Carlson, R. L., Johnson, D. A., et al., 1983. Init. Repts. $D S D P, 72$ : Washington (U.S. Govt. Printing Office).

Berger, W. H., 1979. Impact of deep drilling on paleoceanography. In Talwani, M., Hay, W. W., and Ryan, W.B.F. (Eds.), Deep Drilling Results in the Atlantic Ocean: Continental Margins and Paleoenvironment: Washington (Amer. Geophys. Union), Maurice Ewing Series 3:297-314.

Berggren, W. A., Kent, D. V., Flynn, J. J., and Van Couvering, J. A., in press. Cenozoic geochronology. Geology.

Bolli, H. M., Ryan, W. B. F., et al., 1978. Init. Repts. DSDP, 40: Washington (U.S. Govt. Printing Office).

Bramlette, M. N., and Wilcoxon, J. A., 1967. Middle Tertiary calcareous nannoplankton of the Cipero Section, Trinidad, W. I. Tulane Stud. Geol., 5:93-131.

Bukry, D., 1970. Coccolith age determinations, Leg 2, Deep Sea Drilling Project. In Peterson, M. N. A., Edgar, N. T., et al., Init. Repts. DSDP, 2: Washington (U.S. Govt. Printing Office), 349-355.

1973a. Coccolith stratigraphy, Leg 10, Deep Sea Drilling Project. In Worzel, J. L., Bryant, W., et al., Init. Repts. DSDP, 10: Washington (U.S. Govt. Printing Office), 385-406.

1973b. Low-latitude coccolith biostratigraphic zonation. In Edgar, N. T., Saunders. J. B., et al., Init. Repts. DSDP, 15: Washington (U.S. Govt. Printing Office), 685-703.

1974. Coccoliths as paleosalinity indicators-evidence from Black Sea. Am. Assoc. Pet. Geol. Mem., 20:353-363.

1975. Coccolith and silicoflagellate stratigraphy, northwestern Pacific Ocean, Deep Sea Drilling Project, Leg 32. In Larson, R. L., Moberly, R., et al., Init. Repts. DSDP, 32: Washington (U.S. Govt. Printing Office), 677-692.

1977. Coccolith and silicoflagellate stratigraphy, South Atlantic Ocean, Deep Sea Drilling Project Leg 39. In Supko, P. R., Perch-Nielsen, K., et al., Init. Repts. DSDP, 39: Washington (U.S. Govt. Printing Office), 825-839.

, 1978a. Cenozoic silicoflagellate and coccolith stratigraphy, southeastern Atlantic Ocean, Deep Sea Drilling Project Leg 40. In Bolli, H. M., Ryan, W. B. F., et al., Init. Repts. DSDP, 40: Washington (U.S. Govt. Printing Office), 635-649.

1978b. Cenozoic silicoflagellate and coccolith stratigraphy, northwestern Atlantic Ocean, Deep Sea Drilling Project, Leg 43. In Benson, W. E., Sheridan, R. E., et al., Init. Repts. DSDP, 44: Washington (U.S. Govt. Printing Office), 775-805.

Bukry, D., and Bramlette, M. N., 1968. Stratigraphic significance of two genera of Tertiary calcareous nannofossils. Tulane Stud. Geol., 6:149-155.

Bybell, L. M., 1982. Late Eocene to early Oligocene calcareous nannofossils in Alabama and Mississippi. Gulf Coast Assoc. Geol. Soc. Trans., 32:295-302.

Bybell, L. M., and Gartner, S., 1972. Provincialism among mid-Eocene calcareous nannofossils. Micropaleontology, 18:319-336.

Fischer, A. G., and Arthur, M. A., 1977. Secular variations in the pelagic realm. In Cook, H. E., and Enos, P. (Eds.), Deep-Water Carbonate Environments, Soc. Econ. Paleontol. Mineral. Spec. Publ., 25:19-50.

Gaarder, K. R., 1954. Coccolithineae, Silicoflagellatae, Ptenospermataceae and other forms from the Michael Sars North Atlantic Deep 
Sea Expedition, 1910. Rep. Sci. Results Michael Sars North Atlantic Deep-Sea Exped., 2:3-20.

Gartner, S., 1967. Probable origin of an enigmatic calcareous nannofossil. Micropaleontology, 13:513.

1977. Calcareous nannofossil biostratigraphy and revised zonation of the Pleistocene. Mar. Micropaleontol., 2:1-25.

Gartner, S., and Bukry, D., 1969. Tertiary holococcoliths. J. Paleontol., 43:1213-1221.

Gran, H. H., and Braarud, T., 1935. A qualitative study of the phytoplankton in the Bay of Fundy and the Gulf of Maine. J. Biol. Board Can., 1:279-467.

Haq, B. U., 1984. Jurassic to Recent nannofossil biochronology: an up date. In Haq, B. U. (Ed.), Nannofossil Biostratigraphy: Stroudsberg, Pennsylvania (Hutchinson Ross Publishing Co.), Benchmark Papers, Geology, 78:358-378.

Haq, B. U., Berggren, W. A., and Van Couvering, J. A., 1977. Corrected age of the Pliocene/Pleistocene boundary. Nature, 269: 483-488.

Hay, W. W., 1970. Calcareous nannofossils from cores recovered on Leg 4. In Bader, R. G., Gerard, R. D., et al., Init. Repts. DSDP, 4: Washington (U.S. Govt. Printing Office), 455-501.

Hsü, K. J., LaBrecque, J. L., et al., 1984. Init. Repts. DSDP, 73: Washington (U.S. Govt. Printing Office).

Hulbert, E. M., 1962. Phytoplankton in the southwestern Sargasso Sea and north equatorial current, February 1961. Limnol. Oceanogr., 7:307-315.

Hulbert, E. M., and Rodman, J., 1963. Distribution of phytoplankton with respect to salinity between the coast of southern New England and Bermuda. Limnol. Oceanogr., 8:263-269.

Jiang, M. -J., and Gartner, S., 1984. Neogene and Quaternary calcareous nannofossil biostratigraphy of the Walvis Ridge. In Moore, T. C., Jr., Rabinowitz, P. D., et al., Init. Repts. DSDP, 74: Washington (U.S. Govt. Printing Office), 561-595.

Kennett, J. P., 1978. The development of planktonic biogeography in the Southern Ocean during the Cenozoic. Mar. Micropaleontol., 3:301-345.

Kennett, J. P., von der Borch, C. C., and Scientific Party, 1983. Leg 90 makes latitudinal traverse. Geotimes, 28:16-19.

LaBrecque, J. L., Hsü, K. J., Carman, M. F., Jr., Karpoff, A. M., McKenzie, J. A., Percival, S. F., Jr., Petersen, N. P., Pisciotto, K. A., Schreiber, E., Tauxe, L, Tucker, P., Weissert, H. J., and Wright, R., 1983. DSDP Leg 73: contributions to Paleogene stratigraphy in nomenclature, chronology and sedimentation rates. Palaeogeogr., Palaeoclimatol., Palaeoecol., 42:91-125.

LaBrecque, J. L., and Rabinowitz, P. D., 1977. Magnetic anomalies bordering the continental margin of Argentina. Am. Assoc. Pet. Geol., Spec. Map Ser., Tulsa, Oklahoma.

Lang, T. H., and Watkins, D. K., 1984. Cenozoic calcareous nannofossils from DSDP Leg 77: biostratigraphy and delineation of hiatuses. In Buffler, R. T., Schlager, W., et al., Init. Repts. DSDP, 77: Washington (U.S. Govt. Printing Office), 629-648.

Lefort, F, 1972. Quelques caractères morphologiques de deux specés actuelles de Braarudosphaera (Chrysophycées, Coccolithophoracées). Botaniste, 55:81-93.

1973. Étude de quelques Coccolithophoracées marins appartenaut aux genres Hymenomonas, Ochrosphaera, Braarudosphaera [Thése de $3^{\text {éme }}$ cycle]. Université Rennes, Rennes, France.

Loeblich, A. R., Jr., and Tappan, H., 1966. Annotated index and bibliography of the calcareous nannoplankton. Phycologia, 5:81-216. , 1968. Annotated index and bibliography of the calcareous nannoplankton III. J. Paleontol., 42:584-598.

1969. Annotated index and bibliography of the calcareous nannoplankton III. J. Paleontol., 43:568-588.

1970a. Annotated index and bibliography of the calcareous nannoplankton IV. J. Paleontol., 44:558-574.

$1970 \mathrm{~b}$. Annotated index and bibliography of the calcareous nannoplankton VI. Phycologia, 9:157-174.

1971. Annotated index and bibliography of the calcareous nannoplankton VI. Phycologia, 10:315-339.

, 1973. Annotated index and bibliography of the calcareous nannoplankton VII. J. Paleontol., 47:715-759.

Luyendyk, B. P., Cann, J. R., et al., 1979. Init. Repts. DSDP, 49: Washington (U.S. Govt. Printing Office).
McIntyre, A., and Bé, A. W. H., 1967. Modern Coccolithophoridae of the Atlantic Ocean-I, placoliths and cyrtoliths. Deep-Sea Res., 14:561-597.

Manivit, H., 1984. Paleogene and Upper Cretaceous calcareous nannofossils from Deep Sea Drilling Project Leg 74. In Moore, T. C., Jr., Rabinowitz, P. D., et al., Init. Repts. DSDP, 74: Washington (U.S. Govt. Printing Office), 475-499.

Martini, E., 1967. Nannoplankton und Umlagerungsershceinungen in Persischen Golf und in nordlichen Arabischen Meer. N. Jb. Geol. Palaont. Mh., 10:579-607.

1971. Standard Tertiary and Quaternary calcareous nannoplankton zonation. In Farinacci, A. (Ed.), Proc. II Plankt. Conf. Roma: Rome (Edizioni Tecnoscienza), 2:739-785.

Martini, E., and Bramlette, M. N., 1963. Calcareous nannoplankton from the experimental Mohole Drilling. J. Paleontol., 37:845-856.

Maxwell, A. E., Von Herzen, R. P., et al., 1970. Init. Repts. DSDP, 3: Washington (U.S. Govt. Printing Office).

Mazzei, R., Raffi, I., Rio, D., Hamilton, N., and Cita, M. B., 1979. Calibration of late Neogene calcareous plankton datum planes with the paleomagnetic record of Site 397 and correlation with Moroccan and Mediterranean sections. In von Rad, U., Ryan, W. B. F., et al., Init. Repts. DSDP, 47, Pt. 1: Washington (U.S. Govt. Printing Office), 375-389.

Moore, T. C., Jr., Rabinowitz, P. D., et al., 1984. Init. Repts. DSDP, 74: Washington (U.S. Govt. Printing Office).

Noël, D., and Melguen, M., 1978. Nannofacies of Cape Basin and Walvis Ridge sediments, Lower Cretaceous to Pliocene (Leg 40). In Bolli, H. M., Ryan, W. B. F., et al., Init. Repts. DSDP., 40: Washington (U.S. Govt. Printing Office), 487-524.

Okada, H., and Bukry, D., 1980. Supplementary modification and introduction of code numbers to the "Low-latitude coccolith biostratigraphic zonation” (Bukry, 1973; 1975). Mar. Micropaleontol., 5:321-325.

Parker, M. E., 1984. Calcareous nannofossil biostratigraphy of Deep Sea Drilling Project Leg 82 Sites 558 and 563, North Atlantic Ocean in the vicinity of the Azores [M. S. thesis]. Florida State University, Tallahassee, Florida.

Perch-Nielsen, K., 1977. Albian to Pleistocene calcareous nannofossils from the western South Atlantic, DSDP Leg 39. In Supko, P. R., Perch-Nielsen, K., et al., Init. Repts. DSDP, 39: Washington (U.S. Govt. Printing Office), 699-823.

Perch-Nielsen, K., McKenzie, J., and He, Q., 1982. Biostratigraphy and isotope stratigraphy and the "catastrophic" extinction of calcareous nannoplankton at the Cretaceous/Tertiary boundary. In Silver, L. T., and Schultz, P. H. (Eds.), Geological Implications of Impacts of Large Asteroids and Comets on the Earth. Geol. Soc. Am. Spec. Pap. No. 190, pp. 353-371.

Peterson, M. N. A., Edgar, N. T., et al., 1970. Init. Repts. DSDP, 2: Washington (U.S. Govt. Printing Office).

Prell, W. L., 1982. Oxygen and carbon isotope stratigraphy for the Quaternary of Hole 502B: evidence for two modes of isotopic variability. In Prell, W. L., Gardner, J. V., et al., Init. Repts. DSDP, 68: Washington (U.S. Govt. Printing Office), 455-464.

Proto Decima, F., Medizza, F., and Todesco, L., 1978. Southeastern Atlantic Leg 40 calcareous nannofossils. In Bolli, H. M., Ryan, W. B. F., et al., Init. Repts. DSDP, 40: Washington (U.S. Govt. Printing Office), 571-634.

Rio, D., 1982. The fossil distribution of coccolithophore genus $\mathrm{Ge}$ phyrocapsa Kamptner and related Plio-Pleistocene chronostratigraphic problems. In Prell, W. L., Gardner, J. V., et al., Init. Repts. DSDP, 68: Washington (U.S. Govt. Printing Office), 325-343.

Roth, P. H., 1970. Oligocene calcareous nannoplankton biostratigraphy. Eclogae. Geol. Helv., 63:799-881.

1974. Calcareous nannofossils from the northwestern Indian Ocean, Leg 24, Deep Sea Drilling Project. In Fischer, R. L., Bunce, E. T., et al., Init. Repts. DSDP, 24: Washington (U.S. Govt. Printing Office), 969-994.

Roth, P. H., Baumann, P., and Bertolino, V., 1971. Late Eocene-Oligocene calcareous nannoplankton from central and northern Italy. In Farinacci, H. (Ed.), Proc. II Plankt. Conf. Roma: Rome (Edizioni Tecnoscienza), 2:1069-1097.

Roth, P. H., and Thierstein, H. R., 1972. Calcareous nannoplankton: Leg 14 of the Deep Sea Drilling Project. In Hayes, D. E., Pimm, 
A. C., et al., Init. Repts. DSDP, 14: Washington (U.S. Govt. Printing Office), 421-485.

Sclater, G., Anderson, R. N., and Bell, M. L., 1971. Elevation of ridges and evolution of the central eastern Pacific. J. Geophys. Res., 76:7888-7915.

Siesser, W. G., 1983. Paleogene calcareous nannoplankton biostratigraphy: Mississippi, Alabama, and Tennessee. Miss. Dept. Nat. Res. Bull., 125:1-61.

Smayda, T. J., 1966. A quantitative analysis of the ecological conditions and the phytoplankton dynamics at $8^{\circ} 45^{\prime} \mathrm{N}, 79^{\circ} 23^{\prime} \mathrm{W}$ from November 1954 to May 1957. Inter-Am. Tropical Tuna Comm. Bull., II:353-612.

Supko, P. R., Perch-Nielsen, K., et al., 1978. Init. Repts. DSDP, 39: Washington (U.S. Govt. Printing Office).

Takayama, T., 1970. The Pliocene-Pleistocene boundary in the Lamont Core, V21-98 and at Le Castella, Southern Italy. J. Mar. Geol., 6:70-77.

Thierstein, H. R., 1981. Late Cretaceous nannoplankton and the change at the Cretaceous-Tertiary boundary. In Warme, J. E., and Winterer, E. L. (Eds.), The Deep Sea Drilling Project: $A$ Decade of Progress. Soc. Econ. Paleontol. Mineral. Spec. Publ., 32: 355-394.

Thierstein, H. R., and Okada, H., 1979. The Cretaceous/Tertiary boundary event in the North Atlantic. In Tucholke, B. E., Vogt, P. R., et al., Init. Repts. DSDP, 43: Washington (U.S. Govt. Printing Office), 601-616.

Vail, P. R., Mitchem, R. M., Jr., and Thompson, S., 1977. Seismic stratigraphy and global changes of sea level, part 3: relative changes of sea level from coastal onlap. Am. Assoc. Pet. Geol. Bull., 26: 63-98.

van Heck, S. E., 1979a. Bibliography and taxa of calcareous nannoplankton. Int. Nannoplankton Assoc. Newslett., 1:AB1-5, A112, B1-27.

1979b. Bibliography and taxa of calcareous nannoplankton.

Int. Nannoplankton Assoc. Newslett., 1:AB VI, A13-28, B28-42. , 1980a. Bibliography and taxa of calcareous nannoplankton. Int. Nannoplankton Assoc. Newslett., 2:5-34.

1980b. Bibliography and taxa of calcareous nannoplankton. Int. Nannoplankton Assoc. Newslett., 2:43-81.

1981a. Bibliography and taxa of calcareous nannoplankton. Int. Nannoplankton Assoc. Newslett., 3:4-41.

1981b. Bibliography and taxa of calcareous nannoplankton. Int. Nannoplankton Assoc. Newslett., 3:51-86.

1982a. Bibliography and taxa of calcareous nannoplankton. Int. Nannoplankton Assoc. Newslett., 4:7-50.

1982b. Bibliography and taxa of calcareous nannoplankton. Int. Nannoplankton Assoc. Newslett., 4:65-96.

1983a. Bibliography and taxa of calcareous nannoplankton. Int. Nannoplankton Assoc. Newslett., 5:4-13.

1983b. Bibliography and taxa of calcareous nannoplankton. Int. Nannoplankton Assoc. Newslett., 5:29-47.

Wise, S. W., Jr., 1983. Mesozoic and Cenozoic calcareous nannofossils recovered by Deep Sea Drilling Project Leg 71 in the Falkland Plateau region, southwest Atlantic Ocean. In Ludwig, W. J., Krasheninnikov, V. A., et al., Init. Repts. DSDP, 71: Washington (U.S. Govt. Printing Office), 481-550.

Wise, S. W., and Kelts, K. R., 1972. Inferred diagenetic history of a weakly silicified deep sea chalk. Gulf Coast Assoc. Geol. Soc. Trans., 22:177-203.

Date of Initial Receipt: 21 October 1983

Date of Acceptance: 1 June 1984

\section{APPENDIX}

Calcareous Nannofossils Considered in this Chapter in Alphabetical Order by Species Epithets

Sphenolithus abies Deflandre, 1953

Cyclicargolithus abisectus (Müller) Wise, 1973

Chiasmolithus altus Bukry and Percival, 1967

Amaurolithus amplificus (Bukry and Percival) Gartner and Bukry, 1975

Oolithotus antillarum (Cohen) Reinhardt, 1968

Scyphosphaera apsteinii Lohmann, 1902

Discoaster asymmetricus Gartner, 1969
Discoaster aulakos Gartner, 1967

Sphenolithus belemnos Bramlette and Wilcoxon, 1967

Discoaster bellus Bukry and Percival, 1971

Discoaster berggrenii Bukry, 1971

Braarudosphaera bigelowii (Gran and Braarud) Deflandre, 1947

Zygrhablithus bijugatus (Deflandre) Deflandre, 1959

Reticulofenestra bisecta (Hay, Mohler and Wade) Roth, 1970

Discoaster bollii Martini and Bramlette, 1963

Discoaster braarudii Bukry, 1971

Discoaster brouweri Tan Sin Hok, 1927

Catinaster calyculus Martini and Bramlette, 1963

Sphenolithus capricornutus Bukry and Percival, 1971

Gephyrocapsa caribbeanica Boudreaux and Hay, 1967

Triquetrorhabdulus carinatus Martini, 1965

Helicosphaera carteri (Wallich) Kamptner, 1954

Discoaster challengeri Bramlette and Riedel, 1954

Sphenolithus ciperoensis Bramlette and Wilcoxon, 1967

Rhabdosphaera clavigera Murray and Blackman, 1898

Catinaster coalitus Martini and Bramlette, 1963

Scyphosphaera conica Kamptner, 1955

Sphenolithus conicus Bukry, 1971

Minylitha convallis Bukry, 1973

Umbilicosphaera cricota (Gartner) Cohen and Reinhardt, 1968

Ceratolithus cristatus Kamptner, 1950

Discoaster deflandrei Bramlette and Riedel, 1954

Amaurolithus delicatus Gartner and Bukry, 1975

Sphenolithus delphix Bukry, 1973

Sphenolithus distentus (Martini) Bramlette and Wilcoxon, 1967

Crenalithus doronicoides (Black and Barnes) Roth, 1973

Discoaster druggii Bramlette and Wilcoxon, 1967

Coccolithus eopelagicus (Bramlette and Riedel) Bramlette and Sullivan, 1961

Discoaster exilis Martini and Bramlette, 1963

Clausicoccus fenestratus (Deflandre and Fert) Prins, 1979

Cyclicargolithus floridanus (Roth and Hay) Bukry, 1971

Micrantholithus flos Deflandre, 1950

Coccolithus formosus (Kamptner) Wise, 1973

Scapholithus fossilis Deflandre, 1954

Scyphosphaera globulata Bukry and Percival, 1971

Discoaster hamatus Martini and Bramlette, 1963

Sphenolithus heteromorphus Deflandre, 1953

Reticulofenestra hillae Bukry and Percival, 1971

Syracosphaera histrica Kamptner, 1941

Emiliania huxleyi (Lohmann) Hay and Mohler, 1967

Discoaster intercalcaris Bukry, 1971

Scyphosphaera intermedia Deflandre, 1942

Peritrachelina joidesa Bukry and Bramlette, 1969

Scyphosphaera kamptneri Müller, 1974

Discoaster kugleri Martini and Bramlette, 1963

Pseudoemiliania lacunosa (Kamptner) Gartner, 1969

Scyphosphaera lagena Kamptner, 1955

Leptodiscus larvalis Bukry and Bramlette, 1969

Calcidiscus leptoporus (Murray and Blackman) Loeblich and Tappan, 1978

Reticulofenestra lockeri Müller, 1970

Discoaster loeblichii Bukry, 1971

Calcidiscus macintyrei (Bukry and Bramlette) Loeblich and Tappan, 1978

Triquetrorhabdulus milowii Bukry, 1971

Lanternithus minutus Stradner, 1962

Coccolithus miopelagicus Bukry, 1971

Umbilicosphaera mirabilis Lohmann, 1902

Discoaster moorei Bukry, 1971

Sphenolithus moriformis (Brönnimann and Stradner) Bramlette and Wilcoxon, 1967

Sphenolithus neoabies Bukry and Bramlette, 1969

Discoaster neohamatus Bukry and Bramlette, 1969

Coronocyclus nitescens (Kamptner) Bramlette and Wilcoxon, 1967

Gephyrocapsa oceanica Kamptner, 1943

Pontosphaera ovata (Levin and Joerger) Proto-Decima, Medizza and Todesco, 1978

Coccolithus pelagicus (Wallich) Schiller, 1930

Discoaster pentaradiatus Tan Sin Hok, 1927

Sphenolithus predistentus Bramlette and Wilcoxon, 1967 
CALCAREOUS NANNOFOSSILS, SITES 558 AND 563, NORTH ATLANTIC OCEAN

Amaurolithus primus (Bukry and Percival) Gartner and Bukry, 1975 Rhabdosphaera procera (Martini) Jafar, 1975

Sphenolithus pseudoradians Bramlette and Wilcoxon, 1967

Reticulofenestra pseudoumbilica (Gartner) Gartner, 1969

Scyphosphaera pulcherrima Deflandre, 1942

Discoaster quinqueramus Gartner, 1969

Scyphosphaera recurvata Deflandre, 1942

Isthmolithus recurvus Deflandre in Deflandre and Fert, 1954

Braarudosphaera rosa Levin and Joerger, 1967

Scyphosphaera rottiensis Jafar, 1975

Ceratolithus rugosus Bukry and Bramlette, 1968
Triquetrorhabdulus rugosus Bramlette and Wilcoxon, 1967

Pontosphaera segmenta (Bukry and Bramlette) Jafar and Martini, 1975

Helicosphaera sellii (Bukry and Bramlette) Jafar and Martini, 1975

Bramletteius serraculoides Gartner, 1969

Discoaster surculus Martini and Bramlette, 1963

Discoaster tamalis Kamptner, 1967

Discoaster tanii Bramlette and Riedel, 1954

Ceratolithus telesmus Norris, 1965

Scyphosphaera tubifera Kamptner, 1955

Reticulofenestra umbilica (Levin) Martini and Ritzkowski, 1968

Discoaster variabilis Martini and Bramlette, 1963 


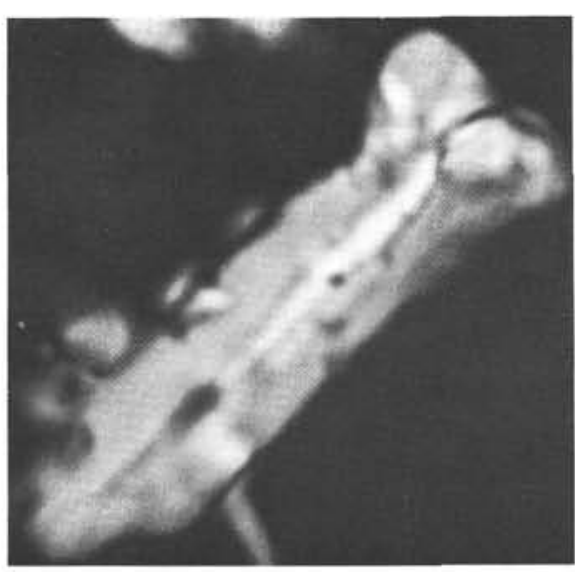

1

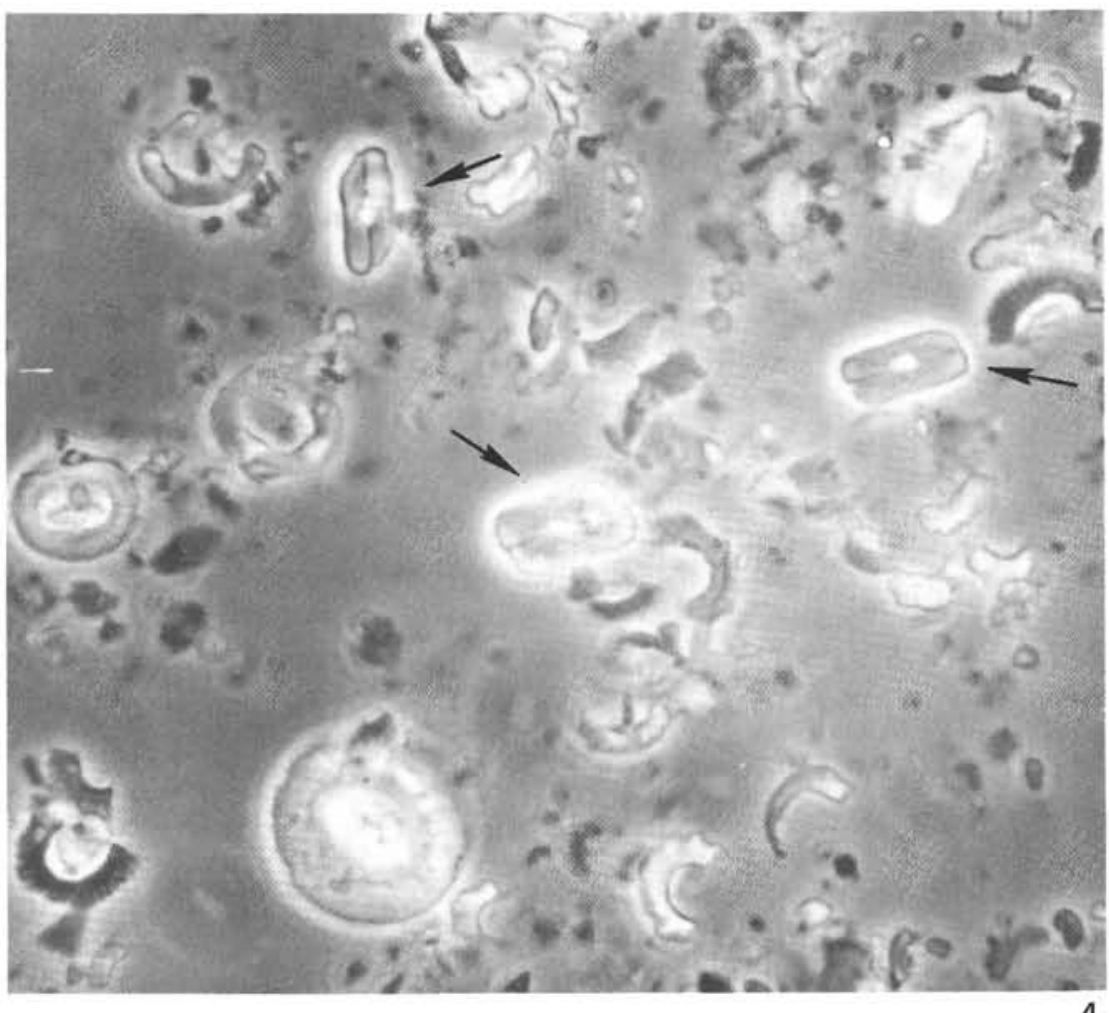

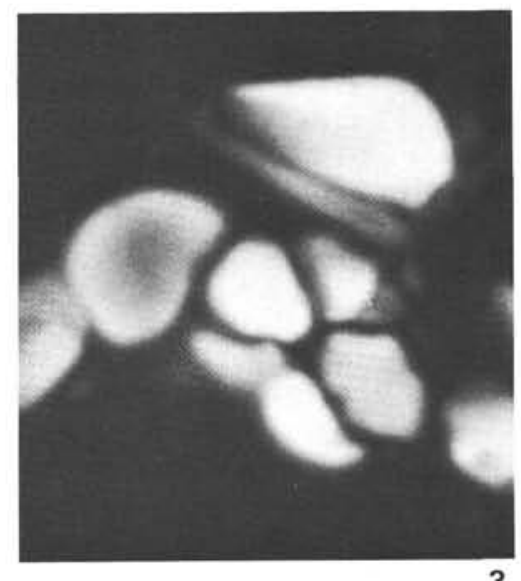

2

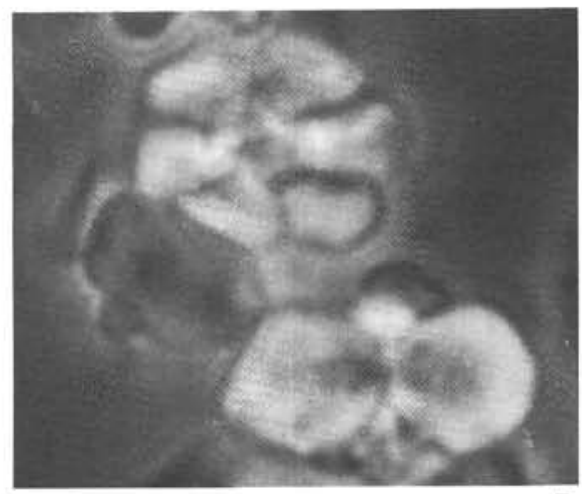

5

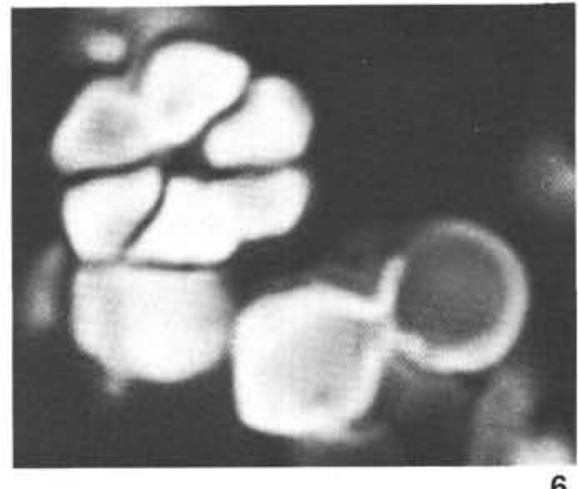

Plate 1. Lower Oligocene. 1-2. Zygrhablithus bijugatus (Deflandre) Deflandre, cross-polarized light, Sample 558-26-1, 16-18 cm. (1) side view, $\times$ 4400. (2) plane view, $\times 6000$. 3. Lanternithus minutus Stradner, cross-polarized light, $\times 6000$, Sample 558-26-1, 16-18 cm. 4. Three specimens of Isthmolithus recurvus Deflandre (see arrows), showing the overgrowth and general state of preservation in the basal Oligocene section, phase contrast light, $\times 1600$, Sample 558-27-2, 42-44 cm. 5-6. Lanternithus minutus Stradner (top specimen) and Zygrhablithus bijugatus (Deflandre) Deflandre (bottom specimen), plan view, $\times 6000$, Sample 563-22-2, 52-54 cm. (5) phase contrast light, (6) cross-polarized light. 

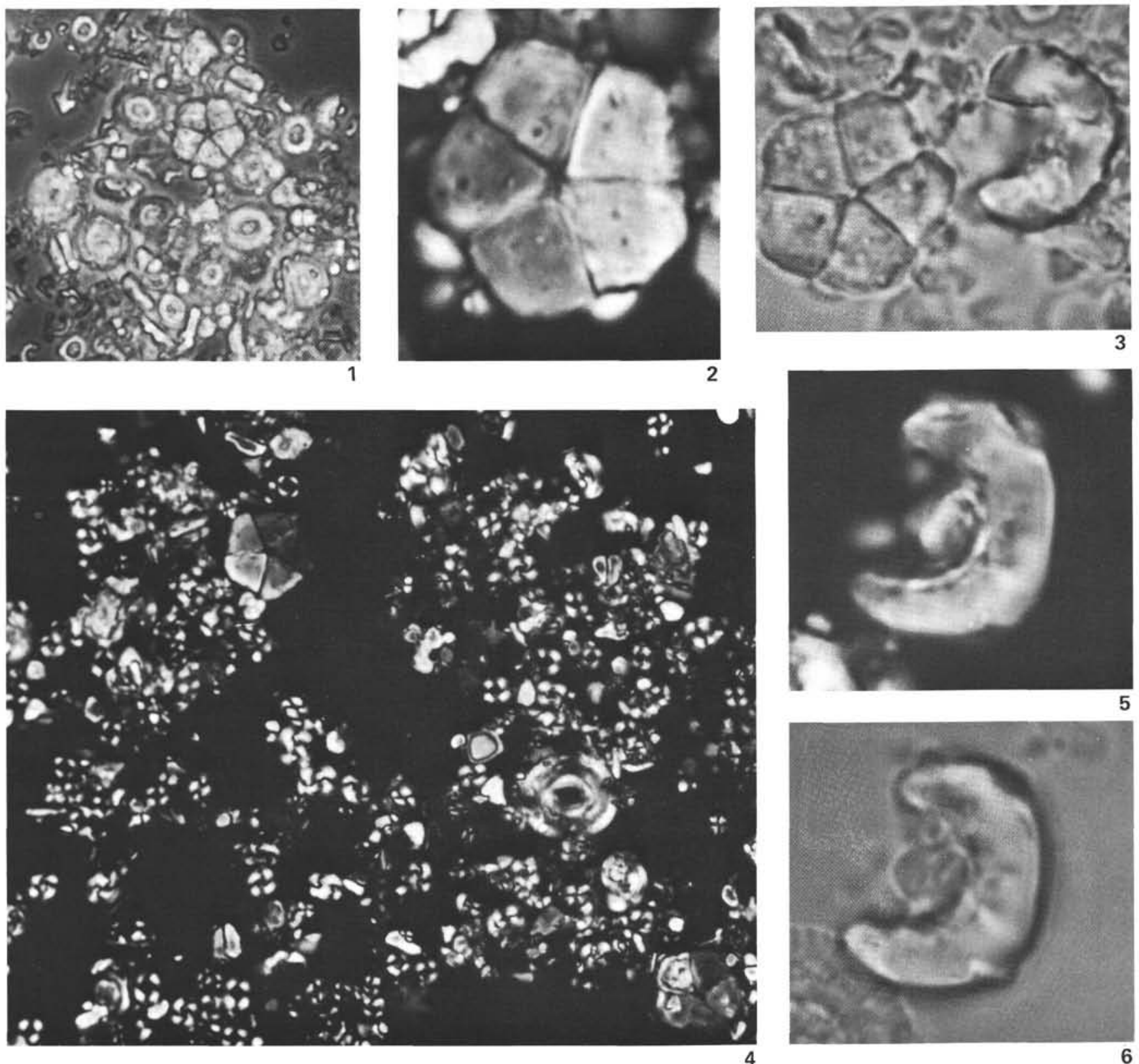

5

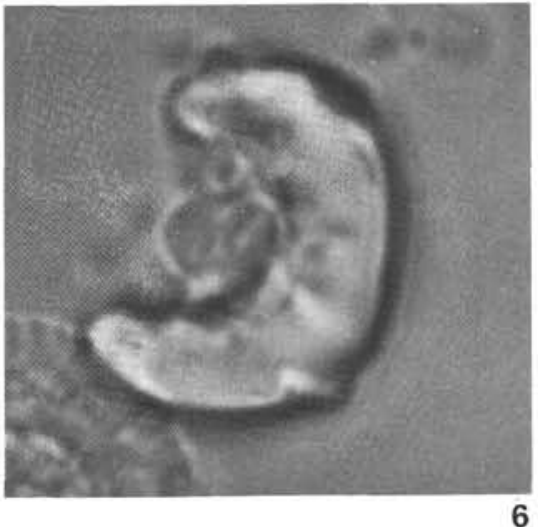

Plate 2. Lower Oligocene. 1. Calcareous nannofossil assemblage with braarudosphaerids comprising approximately $5 \%$ of the assemblage, as in Fig. 4; phase contrast light, $\times 800$, Sample $563-20-6,16-18 \mathrm{~cm}$. 2-3. Intact braarudosphaerid, Sample 563-21,CC. (2) cross-polarized light, $\times$ 3600 , (3) with overgrown Peritrachelina joidesa Bukry and Bramlette (right specimen), transmitted light, $\times 2500$. 4. Calcareous nannofossil assemblage, cross-polarized light, $\times 800$, Sample 563-22-1, 50-52 cm. 5-6. Peritrachelina joidesa Bukry and Bramlette, $\times 3600$, Sample 56321, CC. (5) cross-polarized light, (6) transmitted light. 